University of Tennessee Health Science Center

UTHSC Digital Commons

$12-2013$

\title{
Adenylyl Cyclase 2 Selectively Regulates IL-6 Expression in Human Bronchial Smooth Muscle Cells
}

\author{
Amy Sue Bogard \\ University of Tennessee Health Science Center
}

Follow this and additional works at: https://dc.uthsc.edu/dissertations

Part of the Medical Cell Biology Commons, and the Medical Molecular Biology Commons

\section{Recommended Citation}

Bogard, Amy Sue, "Adenylyl Cyclase 2 Selectively Regulates IL-6 Expression in Human Bronchial Smooth Muscle Cells" (2013). Theses and Dissertations (ETD). Paper 330. http://dx.doi.org/10.21007/ etd.cghs.2013.0029.

This Dissertation is brought to you for free and open access by the College of Graduate Health Sciences at UTHSC Digital Commons. It has been accepted for inclusion in Theses and Dissertations (ETD) by an authorized administrator of UTHSC Digital Commons. For more information, please contact jwelch30@uthsc.edu. 


\title{
Adenylyl Cyclase 2 Selectively Regulates IL-6 Expression in Human Bronchial Smooth Muscle Cells
}

\author{
Abstract \\ Adenylyl cyclase (AC) catalyzes the formation of the ubiquitous second messenger CAMP. AC isoforms \\ differ in their tissue distribution, cellular localization, regulation, and protein interactions, and most cells \\ express multiple isoforms. We hypothesized that CAMP produced by different AC isoforms regulates \\ unique cellular responses. Overexpression of individual isoforms had distinct effects on forskolin (Fsk)- \\ induced expression of a number of known cAMP-responsive genes in human bronchial smooth muscle \\ cells (BSMC) and human embryonic kidney cells (HEK-293). Most notable, in BSMC overexpression and \\ activation of AC2 enhanced interleukin 6 (IL-6) expression, but overexpression of AC3 or AC6 had no \\ effect. IL- 6 production by BSMC was induced by Fsk and select $G$ protein-coupled receptor (GPCR) \\ agonists, though IL-6 levels did not directly correlate with intracellular CAMP levels. At low CAMP \\ concentrations exchange protein directly activated by CAMP (Epac) predominated in mediating the IL- 6 \\ response, but at higher cAMP concentrations protein kinase $A(P K A)$ assumed the larger role. IL- 6 \\ promoter mutations demonstrated that activator protein 1 (AP-1) and cAMP responsive element (CRE) \\ transcription sites were required for CAMP mediated induction. Our findings indicate that AC2 participates \\ in a CAMP-signaling compartment that specifically regulates IL-6 expression in BSMC and that other AC \\ isoforms are excluded from this compartment.

\section{Document Type} \\ Dissertation \\ Degree Name \\ Doctor of Philosophy (PhD) \\ Program \\ Biomedical Sciences \\ Research Advisor \\ Rennolds Ostrom, Ph.D. \\ Keywords \\ Adenylyl cyclase, Bronchial smooth muscle cells, cAMP, G-protein-coupled receptors, Interleukin-6 \\ Subject Categories \\ Medical Cell Biology | Medical Molecular Biology | Medical Sciences | Medicine and Health Sciences \\ Comments \\ Six month embargo expired June 2014
}


Adenylyl Cyclase 2 Selectively Regulates IL-6 Expression in Human Bronchial Smooth Muscle Cells

\author{
A Dissertation \\ Presented for \\ The Graduate Studies Council \\ The University of Tennessee \\ Health Science Center
}

\author{
In Partial Fulfillment \\ Of the Requirements for the Degree \\ Doctor of Philosophy \\ From The University of Tennessee
}

By

Amy Sue Bogard

December 2013 
Copyright (C) 2013 by Amy Sue Bogard. All rights reserved. 


\section{DEDICATION}

Dedicated to the memory of Janie Van Prooijen who consistently offered tremendous support and encouragement to all IPBS students. 


\section{ACKNOWLEDGEMENTS}

I would like to thank my advisor Dr. Rennolds Ostrom for his thoughtful mentorship. He has made my time as a graduate student enjoyable and fulfilling, and on those days that I was completely overwhelmed, he always had just the right words to put me at ease. I would also like to thank my committee Dr. Elizabeth Fitzpatrick, Dr. Edwards Park, Dr. Shannon Matta, Dr. Steven Tavalin, and Dr. Christopher Waters for their guidance. Previous Ostrom lab members Joseph Kaminski and Dr. Muthusamy Thangavel were instrumental in my scientific training. I would like to acknowledge Jason Moore, Cathlyn Chan Jacob Elam, Anna Birg, Joseph Chapman, and Maria Dopico for their help as summer undergraduate research assistants.

I am lucky to have wonderful classmates and appreciate all that they have done for me, from the commiseration after long days and disappointing weeks to celebrations of academic and personal milestones. My friends outside of UT have also been amazing. I am especially grateful for my running and yoga buddies that have helped tremendously in keeping me happy and healthy in Memphis.

Most importantly, I would like to thank my family for all of the love and encouragement they have provided at every step. 


\begin{abstract}
Adenylyl cyclase (AC) catalyzes the formation of the ubiquitous second messenger cAMP. AC isoforms differ in their tissue distribution, cellular localization, regulation, and protein interactions, and most cells express multiple isoforms. We hypothesized that cAMP produced by different $\mathrm{AC}$ isoforms regulates unique cellular responses. Overexpression of individual isoforms had distinct effects on forskolin (Fsk)induced expression of a number of known cAMP-responsive genes in human bronchial smooth muscle cells (BSMC) and human embryonic kidney cells (HEK-293). Most notable, in BSMC overexpression and activation of AC2 enhanced interleukin 6 (IL-6) expression, but overexpression of AC3 or AC6 had no effect. IL-6 production by BSMC was induced by Fsk and select G protein-coupled receptor (GPCR) agonists, though IL-6 levels did not directly correlate with intracellular cAMP levels. At low cAMP concentrations exchange protein directly activated by cAMP (Epac) predominated in mediating the IL-6 response, but at higher cAMP concentrations protein kinase A (PKA) assumed the larger role. IL-6 promoter mutations demonstrated that activator protein 1 (AP-1) and cAMP responsive element (CRE) transcription sites were required for cAMP mediated induction. Our findings indicate that AC2 participates in a cAMP-signaling compartment that specifically regulates IL-6 expression in BSMC and that other AC isoforms are excluded from this compartment.
\end{abstract}




\section{TABLE OF CONTENTS}

CHAPTER 1. INTRODUCTION ....................................................................................1

Bronchial Smooth Muscle and Asthma .................................................................. 1

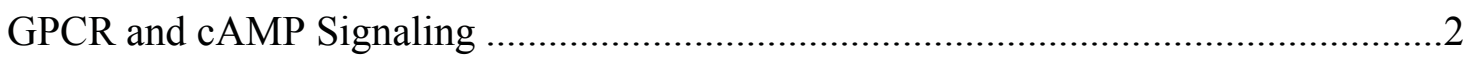

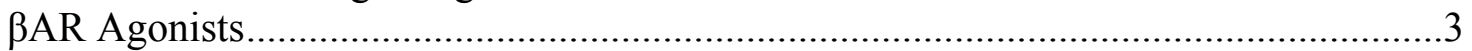

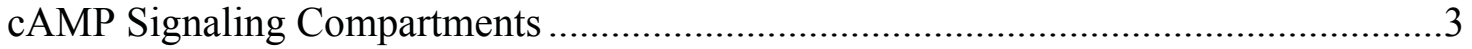

CHAPTER 2. METHODS ...........................................................................................7

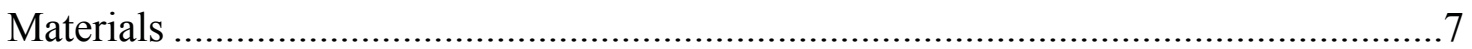

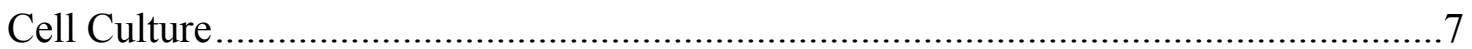

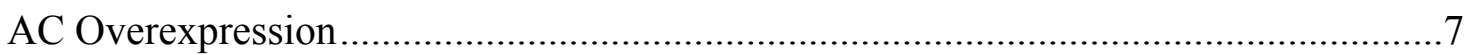

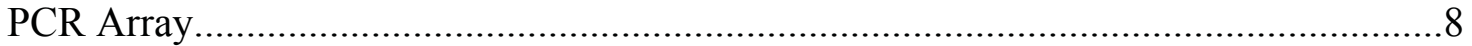

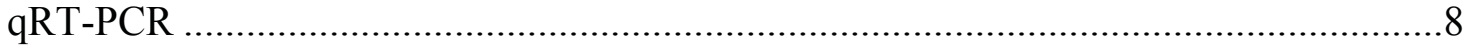

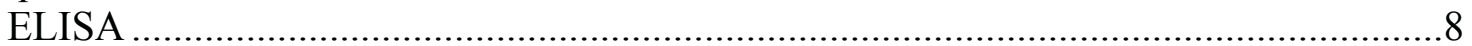

IL-6 Promoter Activity Assay........................................................................ 9

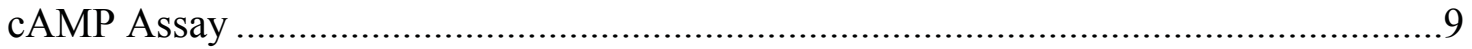

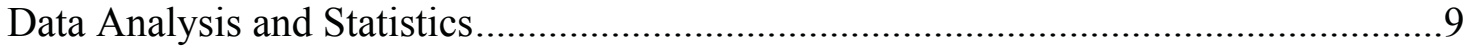

\section{CHAPTER 3. CAMP-MEDIATED GENE REGULATION IS AC}

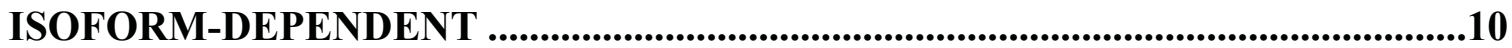

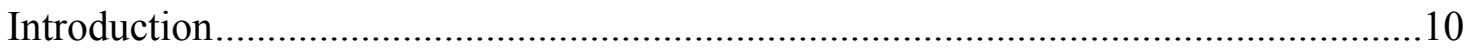

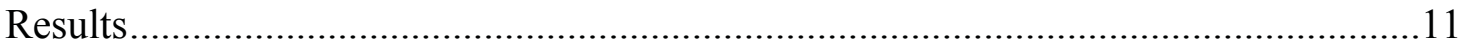

A number of genes are differentially regulated by overexpression and activation of specific AC isoforms ............................................................................... 11

Fsk-induced SST mRNA expression and protein production is specifically regulated by AC6 in BSMC ................................................................................13

Fsk-induced IL-6 mRNA expression and protein production is specifically

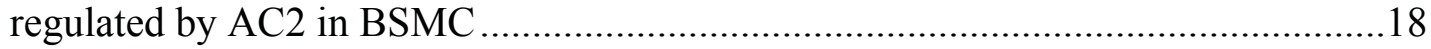

IL-6 basal expression and induction by Fsk differ in BSMC from an asthmatic

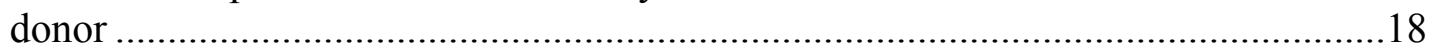

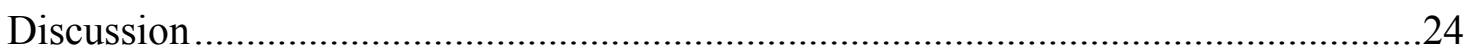

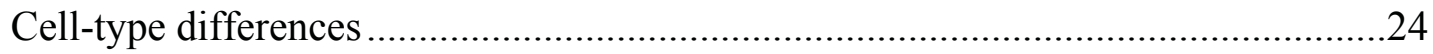

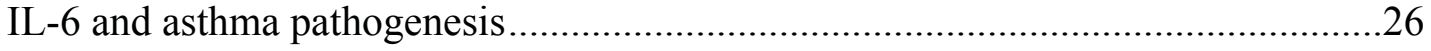

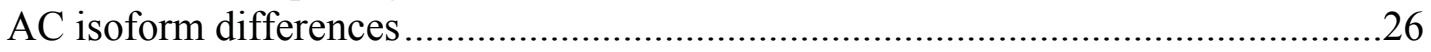

\section{CHAPTER 4. RECEPTOR MEDIATED IL-6 INDUCTION IN BSMC ..................27}

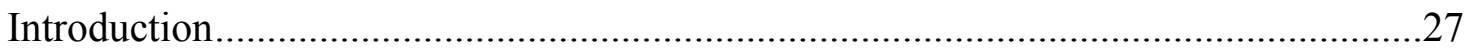

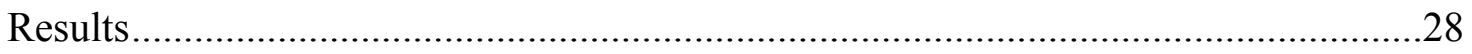

Receptor-mediated induction of IL-6 is enhanced specifically by AC2 …..............28

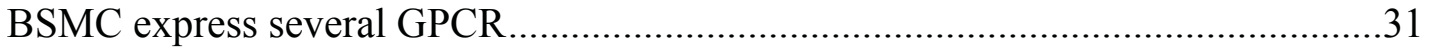

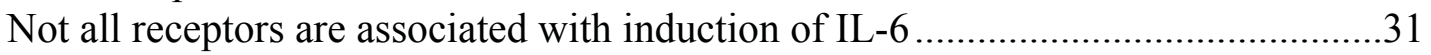

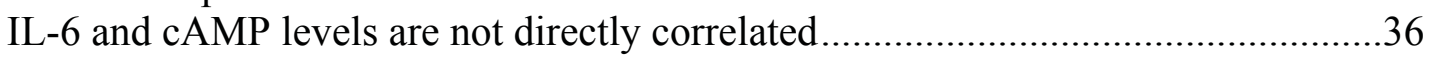

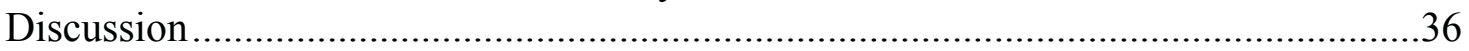




\section{CHAPTER 5. DOWNSTREAM SIGNALING AND PROMOTER ELEMENTS}

ASSOCIATED WITH cAMP INDUCTION OF IL-6 ..................................................39

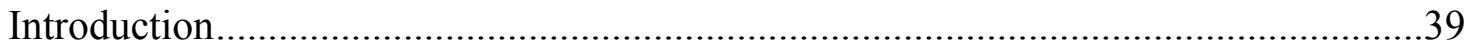

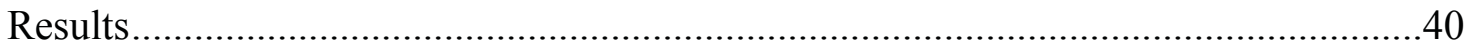

PKA and Epac signaling induce IL-6 production ............................................40

Inhibition of PKC, p38 MAPK, or PI3K does not block Fsk induction of IL-6.......40

Activation of the IL-6 promoter by Fsk requires AP-1 and CRE sites ....................43

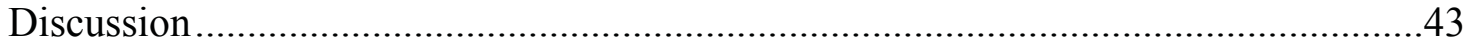

CHAPTER 6. FINAL DISCUSSION AND FUTURE DIRECTIONS.........................47

AC Isoform-Specific Responses ........................................................................47

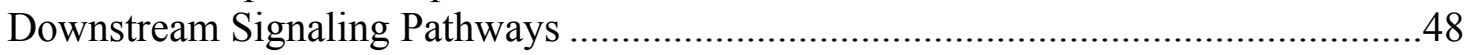

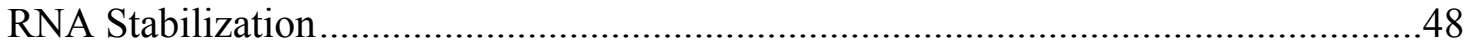

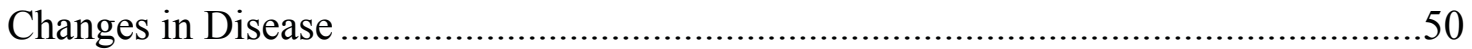

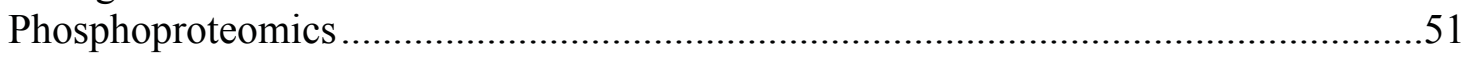

AC Isoform-Specific Regulation of Other Genes ................................................54

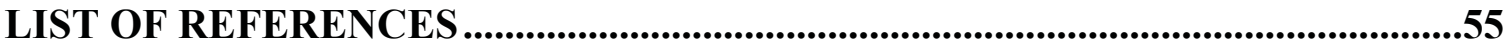

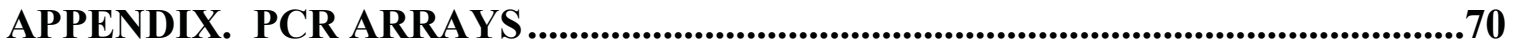

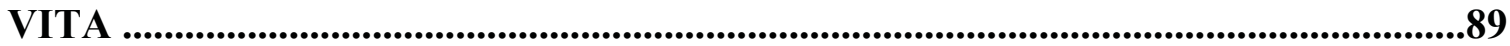




\section{LIST OF TABLES}

Table 1-1. Isoform-specific regulation of adenylyl cyclases ....................................5

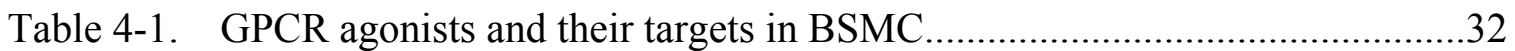

Table A-1. Fsk-induced gene regulation in AC overexpressing BSMC compared to

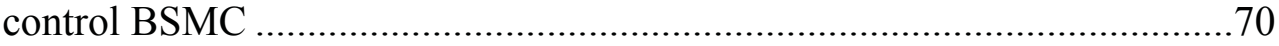

Table A-2. Fsk-induced gene regulation in AC overexpressing HEK compared to

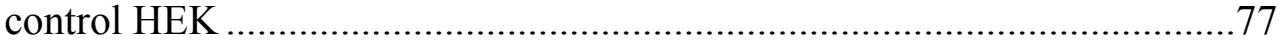

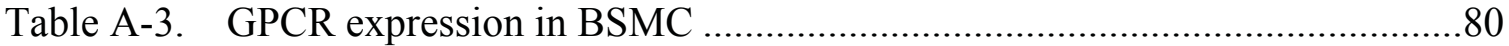




\section{LIST OF FIGURES}

Figure 3-1. Fsk-induced gene regulation in AC overexpressing BSMC compared to

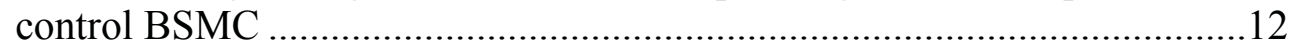

Figure 3-2. Fsk-induced gene regulation in AC overexpressing HEK-293 compared

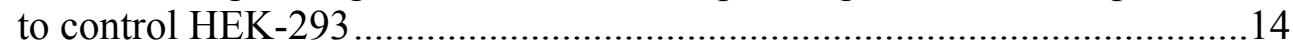

Figure 3-3. Time course of Fsk-induced SST mRNA expression ...................................15

Figure 3-4. Fsk-induced SST mRNA expression in AC overexpressing BSMC …….....16

Figure 3-5. Fsk-induced SST protein production in AC overexpressing BSMC ……....17

Figure 3-6. Time course of Fsk-induced IL-6 mRNA expression....................................19

Figure 3-7. Fsk-induced IL-6 mRNA expression and protein production in AC

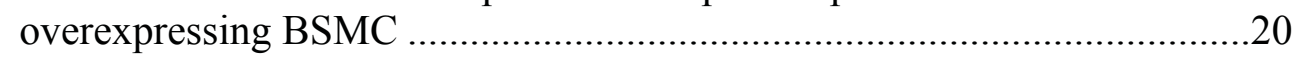

Figure 3-8. Time course of Fsk-stimulated IL-6 protein production ...............................21

Figure 3-9. Inhibition of Fsk-induced IL-6 expression with AC2-selective inhibitor.....22

Figure 3-10. Inhibition of Fsk-induced IL-6 promoter activation with AC6-selective

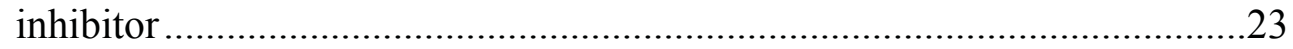

Figure 3-11. Fsk induction of IL-6 in normal and asthmatic BSMC ................................25

Figure 4-1. IL-6 mRNA expression in response to GPCR agonists .................................29

Figure 4-2. IL-6 protein production in response to GPCR agonists ................................30

Figure 4-3. cAMP and IL-6 protein production in response to $\mathrm{G} \alpha_{\mathrm{s}}$-coupled receptor

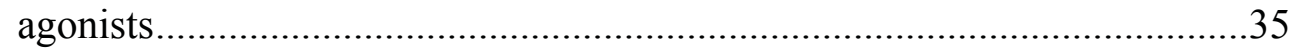

Figure 4-4. cAMP and IL-6 production in BSMC by GPCR agonists alone or with concurrent Fsk treatment..........................................................................

Figure 5-1. IL-6 protein production induced by cAMP analogs ......................................41

Figure 5-2. IL-6 protein production by Fsk in the presence of PKA inhibitor .................42

Figure 5-3. Fsk-induced IL-6 expression in the presence of kinase inhibitors.................44

Figure 5-4. Promoter activity of wild type and mutant IL-6 promoter constructs ...........45

Figure 6-1. cAMP-mediated induction of IL-6 in BSMC ……………........................49 
Figure 6-2. SILAC experimental setup. 


\section{LIST OF ABBREVIATIONS}

\begin{tabular}{|c|c|}
\hline$\beta A R$ & $\beta$-adrenergic receptor \\
\hline $\mathrm{AC}$ & Adenylyl cyclase \\
\hline AKAP & A-kinase anchoring protein \\
\hline AP-1 & Activator protein 1 \\
\hline ASM & Airway smooth muscle \\
\hline АТP & Adenosine triphosphate \\
\hline ATPyS & Adenosine $5^{\prime}-[\gamma$-thio]triphosphate \\
\hline AVP & Arginine vasopressin \\
\hline BALF & Bronchoalveolar lavage fluid \\
\hline BSMC & Bronchial smooth muscle cell \\
\hline Buta & Butaprost \\
\hline cAMP & Cyclic adenosine monophosphate \\
\hline $\mathrm{C} / \mathrm{EBP}$ & Ccaat-enhancer-binding protein \\
\hline CGRP & Calcitonin gene related peptide \\
\hline $\operatorname{COX}$ & Cyclooxygenase \\
\hline $\mathrm{CP}$ & Crossing point \\
\hline CRE & cAMP response element \\
\hline Epac & Exchange protein directly activated by cAMP \\
\hline EPR & Prostaglandin E receptor \\
\hline Fsk & Forskolin \\
\hline GPCR & G protein-coupled receptor \\
\hline HEK-293 & Human embryonic kidney 293A cell line \\
\hline $\mathrm{I} \kappa \mathrm{K}$ & Inhibitor of $\kappa \mathrm{B}$ kinase \\
\hline IBMX & 3-isobutyl-1-methylxanthine \\
\hline IL-6 & Interleukin 6 \\
\hline $\mathrm{IP}_{3}$ & Inositol triphosphate \\
\hline Iso & Isoproternol \\
\hline MAPK & Mitogen-activated protein kinase \\
\hline NECA & 5'-(N-Ethylcarboxamido)adenosine \\
\hline NFkB & Nuclear factor kappa-light-chain-enhancer of activated B cells \\
\hline PDE & Phosphodiesterase \\
\hline $\mathrm{PGD}_{2}$ & Prostaglandin $\mathrm{D}_{2}$ \\
\hline PGE & Prostaglandin E \\
\hline PI3K & Phosphatidylinositide 3-kinases \\
\hline PKA & Protein kinase A \\
\hline $\mathrm{PKC}$ & Protein kinase $\mathrm{C}$ \\
\hline SILAC & Stable isotope labeling by amino acids in cell culture \\
\hline SST & Somatostatin \\
\hline
\end{tabular}




\section{CHAPTER 1. INTRODUCTION}

G protein-coupled receptors (GPCR) are one of the most utilized targets for therapeutic drugs, with up to $50 \%$ of pharmaceuticals acting at these receptors (Salon et al. 2011). Stimulation of a receptor results in generation of second messengers such as cyclic adenosine monophosphate (cAMP), inositol trisphosphate ( $\left.\mathrm{IP}_{3}\right)$, and diacylglycerol, and then signal transduction proceeds through a wide range of downstream effectors. GPCR regulate numerous physiological responses depending on the ligand, receptor, and cell-type. With few second messengers initiating a huge array of potential responses, cells must have mechanisms in place to direct the proper response upon agonist binding, however the mechanisms responsible are poorly understood. We are interested in how cells integrate and separate common signaling pathways and produce distinct responses. We hypothesize that signaling compartments are essential for directing specific cellular responses from a given GPCR. A better understanding of intracellular signaling compartments could allow for more specifically targeted therapeutics.

\section{Bronchial Smooth Muscle and Asthma}

Bronchial smooth muscle cells (BSMC) are critical in the pathogenesis and treatment of asthma. They possess secretory and contractile properties and are involved in the airway hyper-responsiveness, constriction, and remodeling that occur in asthma (Tliba and Panettieri 2009). In asthmatics there is an increase in both the size and number of airway smooth muscle cells (James et al. 2012). Asthmatic BSMC produce and secrete higher levels of inflammatory cytokines and extra cellular matrix proteins, contributing to inflammation and remodeling (Oliver et al. 2006; Johnson et al. 2004). It has been debated whether the pro-inflammatory environment of the asthmatic airway or changes to the cells themselves are responsible for alterations in the structure and function of airway smooth muscle (ASM) in asthma, and there is evidence that both play a role (Shore 2004). Bronchoalveolar lavage fluid (BALF) from allergen-challenged asthmatics causes increased proliferation of normal BSMC in culture, suggesting that the environment could be responsible for some of the phenotypic changes observed in asthma (Naureckas et al. 1999). A number of studies have also shown intrinsic differences in BSMC from asthmatic and nonasthmatic airways (Yeganeh et al. 2013). In vitro BSMC from asthmatic donors show greater contractility in response to histamine (Matsumoto et al. 2007). Genetic changes have also been observed that might explain phenotypic differences in BSMC of asthmatics (Oliver et al. 2006; Martin and Jo 2008; Roth et al. 2004).

GPCR signaling pathways, key to the pathogenesis and treatment of asthma, are also altered in BSMC of asthmatics. An imbalance of pro-contractile to pro-relaxant signaling occurs in asthma (Billington and Penn 2003). $\beta$-adrenergic receptor ( $\beta A R$ ) agonists are less potent inducers of relaxation in carbachol contracted bronchial strips from asthmatic donors, suggesting reduced number or activity of the receptors (Goldie et 
al. 1986). Polymorphisms in $\beta_{2}$ AR have been shown to enhance receptor downregulation and may increase the propensity to develop certain types of asthma (Small et al. 2003; Turki et al. 1995). In addition to changes at the level of the receptor, phosphodiesterase (PDE) 4 expression and activity is increased in asthmatic BSMC, thus reducing cAMP signaling and further shifting the balance toward contraction (Trian et al. 2011). The shift in the balance of contractile to relaxant signaling may contribute to development and severity of asthma.

Airway constriction associated with asthma is treated with $\beta A R$ agonists, which stimulate smooth muscle relaxation and bronchodilation largely through cAMP signaling pathways. Intermittent asthma can be treated at the time of exacerbation with short-acting $\beta A R$ agonists for rapid bronchodilation. In moderate or severe asthma, in addition to short-acting $\beta A R$ agonists as needed, long-acting $\beta A R$ agonists are used in combination with inhaled corticosteroids as maintenance therapy (National Asthma and Prevention 2002). $\beta$ AR agonists cause relaxation by activating cAMP signaling pathways and potassium channel activity, but they can also initiate several other responses, and some are detrimental to the asthmatic airway as discussed below.

\section{GPCR and cAMP Signaling}

GPCR are membrane-spanning proteins with extracellular ligand binding pockets and intracellular coupling to G-proteins. When a hormone, neurotransmitter, or drug binds to a GPCR on the cell surface, it initiates an intracellular signaling cascade. Ligand binding to the GPCR results in a conformational change of the receptor and interactions with G-proteins leading to GTP exchange and dissociation of the heterotrimeric G protein into $G_{\alpha}$ and $G_{\beta \gamma}$ subunits. G-proteins have particular effects depending on their subtype. $\mathrm{G}_{\alpha \mathrm{s}}$ stimulates and $\mathrm{G}_{\alpha \mathrm{i}}$ inhibits activity of adenylyl cyclase (AC), the enzyme that catalyzes the formation of cAMP from adensine triphosphate (ATP). $G_{\alpha q}$ activates phospholipase $\mathrm{C}$ (PLC) that initiates pathways involved in phospholipid and $\mathrm{Ca}^{2+}$ signaling though $\mathrm{IP}_{3}$ and diacylglycerol (Pierce et al. 2002). Each cell can express many GPCR, allowing it to respond to a variety of stimuli (Insel et al. 2012). In BSMC, GPCR signaling regulates cell cycle progression, contraction $\left(G_{\alpha q}, G_{\alpha i}\right)$ and relaxation $\left(G_{a s}\right)$, and gene expression, among many other processes (Billington and Penn 2003).

Following $\mathrm{G}_{\alpha \mathrm{s}}$ stimulation, $\mathrm{AC}$ catalyze the formation of cAMP from ATP. cAMP regulates many cellular processes by activating protein kinase A (PKA) and exchange protein directly activated by cAMP (Epac) (Walsh et al. 1968; de Rooij et al. 1998). cAMP signaling is important in the treatment of asthma, because it causes relaxation of BSMC and dilation of the airway. Upon activation by cAMP, PKA phosphorylates several targets that lead to relaxation of smooth muscle cells (Knox and Tattersfield 1995). Calcium is the primary mediator of contraction, and cAMP signaling pathways oppose contractile pathways by regulating intracellular calcium concentrations and calcium sensitivity of contractile machinery. cAMP inhibits $\mathrm{IP}_{3}$-mediated $\mathrm{Ca}^{2+}$ release and facilitates $\mathrm{Ca}^{2+}$ uptake by the sarcoplasmic reticulum (Murthy 2001). PKA- 
mediated phosphorylation of phospholamban reduces intracellular calcium by relieving phospholamban's inhibition of sarcoplasmic reticulum calcium pump ATPase channels (Prakash et al. 1997; Simmerman et al. 1986). Smooth muscle contraction occurs via myosin cross bridge cycling, and PKA plays a role in regulating the process. Phosphorylation of myosin light chain increases interactions with actin and ATPase activity and results in contraction. PKA phosphorylation promotes relaxation by decreasing the activity of myosin light chain kinase and increasing activity of myosin light chain phosphatase (Conti and Adelstein 1981; Pfitzer 2001; Wooldridge et al. 2004). $\mathrm{G}_{\alpha \mathrm{s}}$ and PKA also facilitate $\beta$ AR-mediated relaxation by activating potassium channels (Kume et al. 1994). The pro-relaxant actions of cAMP are taken advantage of in the treatment of asthma by $\beta A R$ agonist therapies.

\section{BAR Agonists}

$\beta A R$ agonists activate the cAMP signaling pathways described above and are used for bronchoprotection and as rescue treatment in asthma. The goal of $\beta A R$ agonist therapy is to cause relaxation of smooth muscle and bronchodilation through $\mathrm{G}_{a \mathrm{~s}}$ and cAMP signaling, but $\beta A R$ agonists can also induce other signaling pathways that are not favorable in the asthmatic airway. Two main downsides of $\beta A R$ agonists are changes in $\beta A R$ coupling and desensitization. $\beta_{2} A R$ that initially couple to $G_{a s}$ can undergo Gswitching upon exposure to agonist (Daaka et al. 1997b). Switching to $G_{\alpha i}$ coupling leads to activation of mitogen activated protein kinase (MAPK) cascades that induce expression of pro-inflammatory genes and can worsen asthma (Pelaia et al. 2005). $\beta_{2} \mathrm{AR}$ can also exhibit atypical coupling to $\mathrm{G}_{\alpha \mathrm{q}}$, which increases $\mathrm{Ca}^{2+}$ and contractile responses (Anderson 2006). Chronic $\beta$ AR agonist exposure leads to tolerance and desensitization (Cooper et al. 2011; Benovic et al. 1985). Several mechanisms can play a role in desensitization and downregulation of $\beta$ AR following stimulation, which result in decreased responsiveness to therapy over time (Lohse et al. 1990; Giembycz and Newton 2006). Phosphorylation by PKA reduces receptor affinity for $G_{a s}$ and increases affinity for $\mathrm{G}_{\alpha \mathrm{i}}(\mathrm{G}$ switching) (Daaka et al. 1997a). Phosphorylation by $\mathrm{G}$ protein coupledreceptor kinase (GRK) recruits $\beta$ arrestin and facilitates internalization of the receptor via clathrin-coated pits (Benovic et al. 1988). Due to altered coupling and responsiveness of $\beta A R$, treatment with $\beta A R$ agonists alone can lead to increased hyperresponsiveness and inflammation, reduced bronchodilation, and even increased risk of morbidity and mortality (Cheung et al. 1992; Johnston and Edwards 2009; Strandberg et al. 2007). In the future AC may represent a better therapeutic target with fewer unintended effects, since only cAMP pathways would be activated without $\mathrm{G}_{\alpha \mathrm{i}}$ or $\mathrm{G}_{\alpha \mathrm{q}}$ activation.

Approaches targeting AC also have the potential to create larger changes in cAMP, since $\mathrm{AC}$ is the limiting component in $\beta \mathrm{AR}$-stimulated cAMP production(Ostrom et al. 2000b).

\section{cAMP Signaling Compartments}

cAMP is ubiquitous and mediates many responses in BSMC. It would not be practical for cAMP to freely float around the cell activating numerous pathways in 
response to each stimulus, and in fact steady state concentrations would likely not be high enough to activate PKA (Rich et al. 2000). Compartmentalized cAMP signaling allows specific responses to stimuli. The first examples of compartmentation of cAMP signals were described in myocardium where it was observed that of two agonists, epinephrine and prostaglandin $\mathrm{E}_{1}\left(\mathrm{PGE}_{1}\right)$ that act through cAMP and PKA, only epinephrine stimulated contractile force and glycogen phosphorylase activity (Keely 1977, 1979). Homogenate fractionation showed that these stimuli activated PKA in different compartments (Buxton and Brunton 1983). Compartmentation involves components both upstream and downstream of cAMP production. There are nine AC isoforms, which differ in their tissue distribution, regulation (Table 1-1), cellular localization, and associations with other proteins. We hypothesize that the differences among isoforms help them define unique cAMP compartments and lead to AC isoform-specific cellular and physiological responses.

Several components in addition to AC contribute to establishment of cAMP signaling compartments. PDE hydrolyze cAMP, limiting its diffusion from the site of production (Mika et al. 2012). A-kinase anchoring protein (AKAP) scaffolding molecules bring together multiple signaling molecules in complexes (Smith et al. 2006). Over 50 AKAP have been described, and like AC they have unique tissue distribution, intracellular localization, and interactions (Dessauer 2009). In addition to prearranging signal cascades, AKAP bind PDE and regulators of AC, keeping cAMP near the site of production. AKAP and direct complexes containing $\mathrm{AC}$ allow for rapid and precise signaling to generate specific cellular responses downstream of a given stimulus (Ostrom et al. 2012).

Although specific physiological responses following activation of different $\mathrm{G}_{\mathrm{\alpha s}}$ receptors have been known since the 1970's, AC isoform-specific responses have only recently been described. AC5 and AC6, though similar in their structure and regulation, have been shown to have unique roles in the heart through overexpression and knockout studies (Pierre et al. 2009). In cardiomyopathy models, AC6 overexpression increases survival and heart function (Roth et al. 2002). Conversely, it is knockdown of AC5 that is cardioprotective (Vatner et al. 2009). Differences in the localization and associations of AC5 and AC6 appear to drive the isoform-specific effects in cardiomyocytes. AC6 is located outside T-tubules where it colocalizes with $\beta_{2} \mathrm{AR}$ (Timofeyev et al. 2013). AC6 activation in response to $\beta A R$ agonist results in increased L-type calcium current (Timofeyev et al. 2013). AC5 on the other hand is localized to T-tubules where it is in a complex containing PDE, and cAMP diffusion is tightly constrained and unable to alter calcium currents (Timofeyev et al. 2013). Interestingly, even a catalytically inactive AC6 mutant has been shown to have beneficial effects when overexpressed in mice with cardiomyopathy, likely by regulating Akt signaling through direct interactions with $\mathrm{PH}$ domain and Leucine rich repeat Protein Phosphatase 2 (Gao et al. 2009; Gao et al. 2011). The benefits of AC6 signaling in failing hearts are so promising that clinical trials are underway utilizing AC6 gene transfer in patients with congestive heart failure (Tang et al. 2012). Other examples of AC isoform-specific regulation of cellular responses have been described in vascular and airway smooth muscle. In vascular smooth muscle, AC1 mediates proliferation, while AC6 has no impact on proliferation but is involved in 
Table 1-1. Isoform-specific regulation of adenylyl cyclases

\begin{tabular}{|c|c|c|c|}
\hline Regulator & Effect & AC subtype & References \\
\hline \multicolumn{4}{|l|}{ G protein } \\
\hline Gs & Stimulation & All Isoforms & (Iyengar 1993) \\
\hline $\mathrm{Gi}$ & Inhibition & $\mathrm{AC} 1, \mathrm{AC} 5, \mathrm{AC} 6$; not $\mathrm{AC} 2$ & $\begin{array}{l}\text { (Taussig et al. 1993a) (Federman et al. 1992) (Chen and } \\
\text { Iyengar 1993) (Taussig et al. 1994) }\end{array}$ \\
\hline \multirow[t]{3}{*}{$\mathrm{G} \beta \gamma$} & Inhibition & $\mathrm{AC} 1, \mathrm{AC} 5, \mathrm{AC} 6$ & (Taussig et al. 1993b) (Bayewitch et al. 1998) \\
\hline & Stimulation & $\mathrm{AC} 2, \mathrm{AC} 4$ & (Tang and Gilman 1991) (Gao and Gilman 1991) \\
\hline & & Conditional AC5, AC6 & (Gao et al. 2007) \\
\hline Forskolin & Stimulation & All Isoforms (including AC9) & $\begin{array}{l}\text { (Onda et al. 2001) (Premont et al. 1996) (Cumbay and Watts } \\
\text { 2004) }\end{array}$ \\
\hline \multicolumn{4}{|l|}{ Calcium/Calmodulin } \\
\hline $\mathrm{Ca}^{2+} / \mathrm{CaM}$ & Stimulation & $\mathrm{AC} 1, \mathrm{AC} 3, \mathrm{AC} 8$ & (Tang et al. 1991) (Choi et al. 1992) (Cali et al. 1994) \\
\hline $\mathrm{Ca}^{2+}$ & Inhibition & $\mathrm{AC} 5, \mathrm{AC} 6$ & (Yoshimura and Cooper 1992) (Katsushika et al. 1992) \\
\hline \multicolumn{4}{|l|}{ Kinase Regulation } \\
\hline \multirow[t]{2}{*}{$\mathrm{PKC}$} & Stimulation & $\mathrm{AC} 1, \mathrm{AC} 2, \mathrm{AC} 3, \mathrm{AC} 5, \mathrm{AC} 7$ & $\begin{array}{l}\text { (Jacobowitz et al. 1993) (Jacobowitz and Iyengar 1994) (Bol } \\
\text { et al. 1997) (Kawabe et al. 1994) (Watson et al. 1994) }\end{array}$ \\
\hline & Inhibition & AC6 & (Lai et al. 1997) \\
\hline PKA & Inhibition & AC5, AC6 & (Iwami et al. 1995) (Chen et al. 1997) \\
\hline CaM Kinase & Inhibition & $\mathrm{AC} 1, \mathrm{AC} 3$ & (Wayman et al. 1996) (Wei et al. 1996) \\
\hline Raf kinase & Stimulation & $\mathrm{AC} 2, \mathrm{AC} 5, \mathrm{AC} 6$ & (Ding et al. 2004) \\
\hline
\end{tabular}

Reprinted with permission. Ostrom RS, Bogard AS, Gros R, Feldman RD (2012) Choreographing the adenylyl cyclase signalosome: sorting out the partners and the steps. Naunyn Schmiedebergs Arch Pharmacol 385 (1):5-12.

doi:10.1007/s00210-011-0696 
With knowledge of differences among $\mathrm{AC}$ isoforms and compartmentalization of cAMP signaling, we hypothesized that BSMC possess AC isoform-specific regulation of cellular processes. We examined regulation of cAMP-responsive genes in BSMC overexpressing individual $\mathrm{AC}$ isoforms and uncovered a number of genes that are regulated in an isoform-specific manner. AC2-derived cAMP selectively regulates expression of the pro-inflammatory cytokine interleukin 6 (IL-6), a key contributor to the pathogenesis of asthma. cAMP induces IL-6 production, but the levels of cAMP and IL-6 are not directly correlated. AC2's unique localization, regulation and interactions allow it to activate PKA and Epac in a signaling compartment associated with induction of IL-6. AC6-derived cAMP is tied to regulation of other genes, but PDE limit this cAMP pool from activating components involved in IL-6 induction. The cAMP compartments and signaling pathways responsible for stimulation of IL-6 transcription appear to be altered in asthma. $\beta$ AR agonists currently represent the best therapy for treatment of bronchoconstriction in asthma, but some of the signaling pathways activated by $\beta$ AR worsen inflammation and constriction. Targeting AC directly instead of through $\beta A R$ and $G_{\alpha s}$ would stimulate cAMP production without activation of $\mathrm{G}_{\alpha \mathrm{i}}$ and $\mathrm{G}_{\alpha q}$ and could result in greater cAMP production. We show that cAMP can also mediate undesirable responses in BSMC, in particular induction of IL-6. Since cAMP signaling is highly compartmentalized, therapeutics targeting AC6 may stimulate ASM relaxation and bronchodilation without inducing IL-6 production. A greater knowledge of cAMP signaling compartments could allow highly targeted treatment for many diseases, including asthma. 


\section{CHAPTER 2. METHODS}

\section{Materials}

Forskolin (Fsk), isoproterenol (Iso), 3-isobutyl-1-methylxanthine (IBMX), Adenosine 5'-[ $\gamma$-thio $]$ triphosphate (ATPyS), Arginine vasopressin (AVP), prostaglandin $\mathrm{D}_{2}\left(\mathrm{PGD}_{2}\right)$, glucagon, 5'-(N-Ethylcarboxamido)adenosine (NECA), calcitonin gene related peptide (CGRP), and substance $\mathrm{P}$ were purchased from Sigma; 8-Br-cAMP, 8CPT-2Me-cAMP, GF 109203X, SB 202190, ( $($ )-SKF-83566, SQ22,536 and wortmannin from Tocris, and butaprost (buta) from Cayman.

Wild-type and mutant IL-6 promoter luciferase constructs were purchased from the Belgian Coordinated Collections of Micro-organisms/LMBP; LMBP acquisition numbers 4495, 4496, 4498, 4499, 4500 (Vanden Berghe et al. 1998; Plaisance et al. 1997). Luciferase constructs contain 1168 bp of the human IL-6 promoter (wild-type or with point mutations in specific promoter elements) upstream of LUCm in pGL3-Basic vector. Binding sites were altered by site-directed mutagenesis to prevent transcription factor binding at the following promoter elements: 3' or 5' activator protein 1 (AP-1) site, cAMP response element (CRE), CCAAT-enhancer-binding proteins (C/EBP), or nuclear factor kappa-light-chain-enhancer of activated B cells (NFkB) sites.

\section{Cell Culture}

Human BSMC purchased from Lonza were grown in smooth muscle basal medium supplemented with the SmGM-2 bullet kit (5\% fetal bovine serum, $0.1 \%$ insulin, $0.1 \%$ human epidermal growth factor, $0.2 \%$ human fibroblast growth factor- $\beta$, and gentamicin sulfate/amphotericin B; Lonza). Cells were kept at $5 \% \mathrm{CO}_{2}$ and $37^{\circ} \mathrm{C}$. Experiments were performed on cells from passage 5-13.

Human embryonic kidney 293A cell line (HEK-293) purchased from Invitrogen were grown in Dulbecco's Modified Eagle's medium (DMEM) (high glucose) with 10\% fetal bovine serum, $0.1 \mathrm{mM}$ MEM Non-Essential Amino Acids, $2 \mathrm{mM}$ L-glutamine, and $1 \%$ Pen-Strep. Cells were kept at $5 \% \mathrm{CO}_{2}$ and $37^{\circ} \mathrm{C}$.

\section{AC Overexpression}

Adenoviral constructs expressing rat $\mathrm{AC} 2$, rat $\mathrm{AC} 3$, mouse $\mathrm{AC} 6$, or lacZ (control) cDNA were used for $\mathrm{AC}$ overexpression studies in BSMC. The titer of $\mathrm{AC}$ virus was chosen to give similar global cAMP levels in response to $1 \mu \mathrm{M}$ Fsk. Cells were infected 18-24 h before treatment.

Plasmids encoding rat $\mathrm{AC} 2$, human $\mathrm{AC} 6$, or the empty $\mathrm{pEGFP}-\mathrm{n} 1$ vector were used for overexpression studies in HEK-293. Cells were transfected with Cal-Phos 
calcium phosphate transfection kits (Clontech) $24 \mathrm{~h}$ after plating. Cells were transfected with $3 \mu \mathrm{g}$ plasmid per $60 \mathrm{~mm}$ dish. For polymerase chain recaction (PCR) arrays Fsk was added $24 \mathrm{~h}$ after transfection and RNA was isolated $24 \mathrm{~h}$ later as described for PCR array below.

\section{PCR Array}

Following treatment cells were lysed and RNA was isolated using RNeasy kit with on-column DNase step (Qiagen). RNA purity and yield were determined with Nanodrop spectrophotometer. $1 \mu \mathrm{g}$ RNA was reverse transcribed using $\mathrm{RT}^{2}$ first strand kit (SABioscience). cDNA from a single sample was combined with $\mathrm{RT}^{2} \mathrm{SYBR}$ Green Master Mix (SABioscience) and distributed among wells of a multiwell plate containing gene specific and control primers on Human cAMP $/ \mathrm{Ca}^{2+}$ PathwayFinder $\mathrm{RT}^{2}$ Profiler ${ }^{\mathrm{TM}}$ or Human G Protein Coupled Receptors 384HT RT ${ }^{2}$ Profiler ${ }^{\mathrm{TM}}$ PCR Array (SABioscience). The crossing point (CP) was determined by the second derivative maximum algorithm on Roche Lightcycler 480, and fold change was calculated by $\Delta \Delta C P$ method. Melt curve analysis was used to exclude any gene whose CP may have been artificially reduced by multiple amplification products.

\section{qRT-PCR}

For quantitative reverse transcriptase PCR (qRT-PCR) RNA was isolated as described for PCR arrays. $1 \mu \mathrm{g}$ RNA was reverse transcribed using Transcriptor First Strand cDNA Synthesis Kit (Roche) and oligo $(\mathrm{dT})^{18}$ primer. PCR was carried out on Roche Lightcycler 480: $10 \mathrm{~min} 95^{\circ} \mathrm{C}$ followed by 45 cycles of $95^{\circ} \mathrm{C}$ for $10 \mathrm{~s}, 55^{\circ} \mathrm{C}$ for $30 \mathrm{~s}, 72^{\circ} \mathrm{C}$ for $6 \mathrm{~s}$. Amplification was detected by SYBR green (KAPA) and single PCR products were confirmed by melt curve analysis. Fold regulation was calculated by $\Delta \Delta \mathrm{CP}$ method with normalization to RPL13A housekeeping gene. The following genespecific primer sets were used:

IL-6 Forward: GAC AGC CACTCA CCT CTT CA

IL-6 Reverse: AGT GCCTCT TTG CTG CTT TC

SST Forward: TCT GAA CCC AAC CAG AAG GAG AAT

SST Reverse: GCT CAA GCC TCA TTT CAT CCT GCT

\section{ELISA}

IL-6 in cell culture medium was measured by sandwich ELISA according to manufacture's instructions (IL-6: eBioscience or BD bioscience, SST: Phoenix). ELISA were read on Synergy HT (Biotek) plate reader. 


\section{IL-6 Promoter Activity Assay}

BSMC were plated 30,000 cells per well in 12-well plates. $18-24 \mathrm{~h}$ after plating, each well was transfected with $1.8 \mu \mathrm{g}$ plasmid expressing the human IL-6 promoter driving firefly luciferase expression. Cells were co-transfected with $0.4 \mu \mathrm{g}$ Renilla luciferase intended as an internal control constitutively expressed via the thymidine kinase promoter. However, Fsk treatment affected Renilla luciferase expression, so it could not be used for normalization in our studies. All transfections used the CalPhos (Clontech) calcium phosphate kit. Experiments were begun $48 \mathrm{~h}$ post-transfection. Following treatment with the indicated drugs for $6 \mathrm{~h}$, cells were scraped in $250 \mu \mathrm{L}$ passive lysis buffer and assayed using the Dual Luciferase Reporter Assay System (Promega). Luminescence was measured with a TD-20/20 luminometer (Turner Designs).

\section{cAMP Assay}

Cells were washed three times with serum- and NaHCO3-free Dulbecco's Modified Eagle's medium (DMEM) supplemented with $20 \mathrm{mM}$ HEPES, pH 7.4 $(\mathrm{DMEH})$. After equilibration at $37^{\circ} \mathrm{C}$ for $30 \mathrm{~min}$, cells were pretreated with $0.2 \mathrm{mM}$ IBMX, a broadly specific PDE inhibitor, then exposed to the indicated drug for $10 \mathrm{~min}$. Assay medium was aspirated and $150 \mu \mathrm{L} \mathrm{5 \%}$ trichloroacetic acid was added to each well to terminate the reaction. cAMP content of the lysis buffer extract was quantified using the cAMP EIA Kit (Cayman Chemical) using the manufacturer's acetylation protocol.

\section{Data Analysis and Statistics}

Data are presented as the mean \pm SEM. Statistical comparisons ( $t$ tests and oneway analysis of variance) were performed and graphics were generated using GraphPad Prism 5.0f (GraphPad Software Inc., San Diego, CA). 


\section{CHAPTER 3. CAMP-MEDIATED GENE REGULATION IS AC ISOFORM-DEPENDENT}

\section{Introduction}

BSMC predominantly express AC isoforms 2, 4 and 6 (Bogard et al. 2011). These isoforms differ in their regulation (Table 1-1), localization, and interactions with other proteins, giving them the potential to signal in unique ways and control distinct responses even when expressed in the same cell. AC isoforms are divided into 4 groups based on their structure and features of their regulation. Group I consists of AC1, AC3, and AC8; group II: AC2, AC4, and AC7; group III: AC5 and AC6; and group IV: AC9 (Patel et al. 2001). In BSMC, AC6 is localized to lipid rafts where it colocalizes with $\beta_{2} A R$ (Bogard et al. 2011). AC2 and AC4 are excluded from lipid rafts and colocalize with prostaglandin $\mathrm{E}_{2}$ receptors $\left(\mathrm{EP}_{2} \mathrm{R}\right)$ (Bogard et al. 2011). BSMC express several AKAP scaffolding molecules, which arrange signaling complexes and interact with $\mathrm{AC}$ in an isoform-specific manner (Dessauer 2009; Horvat et al. 2012). AC2 is known to interact with multiple AKAP including mAKAP, Yotiao/AKAP9, and AKAP79/150, which bring cAMP produced by AC2 in close proximity to prearranged signaling cascades and regulators such as PDE and phosphatases (Piggott et al. 2008; Kapiloff et al. 2009; Scott et al. 2013). AC6 is also associated with AKAP, and it has been shown to interact directly with AKAP79 (Efendiev et al. 2010).

$A C$ is the limiting factor in determining the maximal effect following $\mathrm{G}_{\alpha \mathrm{s}}$-coupled receptor stimulation (Ostrom et al. 2000b; Gao et al. 1998). Overexpression of AC enhances responses to $\mathrm{G}_{\alpha \mathrm{s}}$-coupled receptor stimulation. In BSMC we use adenoviral overexpression of $\mathrm{AC}$ and subtractive analysis to study responses mediated by individual isoforms. BSMC have low transfection efficiency, but adenoviral infection results in a high percentage of cells overexpressing protein of interest. $\beta$ galactosidase assays confirmed over $90 \%$ of BSMC are positive for lacZ when infected with lacZ encoding adenovirus (Bogard et al. 2011). Knockdown of AC isoforms with siRNA would be an alternative approach and is appealing, since the individual isoforms that are left would be expressed at endogenous levels. However, a high degree of knockdown would be unlikely due to the long half-life of AC, and it would be particularly difficult in poorly transfected cells such as BSMC. We also used newly characterized AC inhibitors selective for particular AC isoforms. A number of pharmacological inhibitors have been used to study AC isoforms, but questions were raised about claims of presumed isoform selectivity of these inhibitors. Two recent studies sought to better describe the effect of inhibitors on particular AC isoforms. Though previously described as an AC5-selective inhibitor, SQ22,536 inhibits AC5 and AC6 equally. The $\mathrm{IC}_{50}$ for SQ22,536 at AC6 is $5.8 \mu \mathrm{M}$, and its $\mathrm{IC}_{50}$ at $\mathrm{AC} 2$ is $210 \mu \mathrm{M}$ (Brand et al. 2013). Conley et. al. screened over 700 compounds and identified SKF-83566 as an AC2-selective inhibitor (2013). We hypothesized that differences among $\mathrm{AC}$ isoforms and compartmentation of cAMP signaling allows $\mathrm{AC}$ isoform-specific regulation of gene expression. We used PCR arrays and isoform-specific AC inhibitors to show that some cAMP-responsive genes are differentially regulated by individual AC isoforms in BSMC. 


\section{Results}

\section{A number of genes are differentially regulated by overexpression and activation of specific AC isoforms}

We tested the hypothesis that cAMP produced by a particular AC isoform has unique effects on gene expression by using PCR arrays to examine $84 \mathrm{cAMP}$ - and $\mathrm{Ca}^{2+}$ sensitive genes. PCR arrays allow simultaneous analysis of multiple genes by utilizing specially designed primer pairs such that all have been optimized for amplification of their specific target under identical conditions. Control or AC overexpressing cells were treated with $1 \mu \mathrm{M}$ Fsk for $24 \mathrm{~h}$ before RNA was isolated and reverse transcribed. The resulting cDNA was diluted in SYBR green master mix and distributed among the wells of the PCR array, each with a primer pair specific to a particular gene or control.

Expression of each gene in AC overexpressing cells treated with Fsk was compared to Fsk-treated control cells. Control cells were transfected with empty pEGFP-n1 vector or treated with an adenovirus expressing the lacZ gene. Fold change was calculated by the $\Delta \Delta \mathrm{CP}$ method with respect to lacZ Fsk-treated cells. A change in expression of 3-fold or greater was the cutoff we used to highlight genes that were upregulated or downregulated upon AC overexpression. For genes that displayed a substantial change with AC overexpression, we examined whether there were differences in gene regulation based on overexpression of individual isoforms. Changes in RNA levels smaller than 3-fold might be physiologically significant, but we choose to focus on the larger responses in this study. Although Fsk treatment altered the expression of many of the genes compared to vehicle in control BSMC, we focused on genes that were differentially regulated with overexpression of specific $\mathrm{AC}$ isoforms.

\section{BSMC}

Adenoviral vectors were used to overexpress AC2, AC3, AC6, or lacZ (control) in BSMC. AC2 and AC6 are natively expressed in distinct membrane microdomains in $\mathrm{BSMC}$ and $\mathrm{AC} 3$ was included as a representative group I isoform. AC overexpression altered the Fsk-induced expression of 13 of the cAMP-sensitive genes tested by at least 3-fold in BSMC (Table A-1). The genes of greatest interest were those that were differentially regulated when different AC were overexpressed. Overexpression of AC3 did not produce a 3-fold or greater change in any of the genes tested; however, AC2 and AC6 had distinct effects on expression of a number of genes (Figure 3-1). AC2 and AC6 overexpression could enhance or attenuate Fsk induction and had differing effects depending on the AC isoform and the gene. A subset of genes was chosen to demonstrate the diversity of responses with different $\mathrm{AC}$ isoforms overexpressed, and results are graphed as fold change with respect to lacZ to illustrate the effect of the individual AC being overexpressed (Figure 3-1). Fsk-mediated expression of amphiregulin (AREG) was augmented to a greater extent by AC6 overexpression than AC2. AC2 overexpression reduced the expression of secretogranin II (SCG2), while 


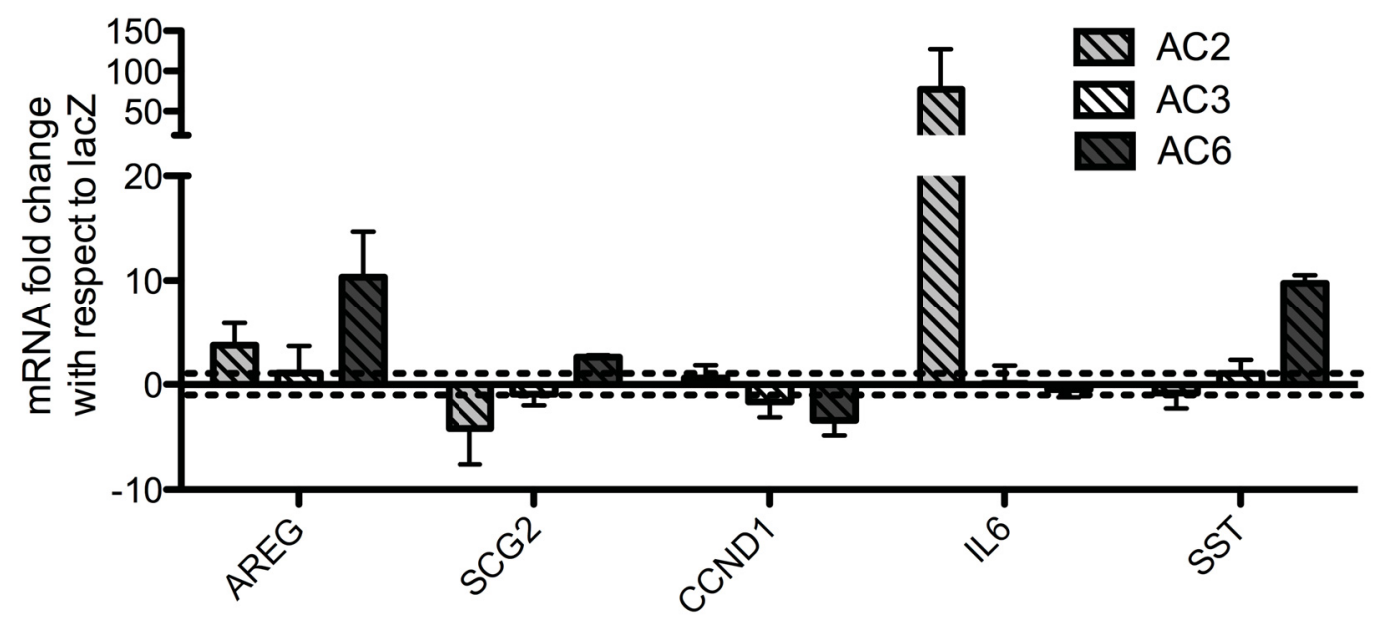

Figure 3-1. Fsk-induced gene regulation in AC overexpressing BSMC compared to control BSMC

$\mathrm{RT}^{2} \mathrm{q}$ PCR arrays (SA Biosciences) were used to measure mRNA levels following $24 \mathrm{~h}$ treatment with $1 \mu \mathrm{M}$ Fsk. mRNA levels of AC overexpressing, Fsk-treated cells are expressed as fold change with respect to lacZ (control), Fsk- treated cells. Amphiregulin (AREG), Secretogranin II (SCG2), Cyclin D1 (CCND1), Interleukin 6 (IL-6),

Somatostatin (SST). Dashed line represents no change with respect to lacZ. Data are presented as fold change with respect to lacZ, mean $\pm S E M, n=3$. 
AC6 overexpression reduced the expression of cyclin D1 (CCND1). Fsk-mediated expression of Interleukin 6 (IL-6) was enhanced only by AC2 overexpression and somatostatin (SST) was enhanced only by AC6 overexpression (Figure 3-1). IL-6 and SST were targets for further study due to their clear AC isoform-dependent patterns of gene regulation in $\mathrm{BSMC}$.

\section{HEK-293}

After finding that gene expression can be regulated differently by AC isoforms in BSMC, HEK-293 cells were tested to determine whether this is a generalizable phenomenon or unique to BSMC. HEK-293 cells were transfected with AC2, AC6, or pEGFP-n1 (control) vectors then exposed to $1 \mu \mathrm{M}$ Fsk for $24 \mathrm{~h}$. As in BSMC, expression of some cAMP-sensitive genes was altered by AC overexpression. Different genes were impacted by AC overexpression in the different cell types, and in HEK-293 the effects of AC overexpression tended to be smaller (Figure 3-2 and Table A-2). As in BSMC, AC overexpression could enhance or reduce Fsk-induced RNA expression in HEK-293 in an isoform-specific manner. Calponin 1 (CNN1) RNA levels were reduced by AC6 overexpression, but not AC2. Gastric inhibitory polypeptide receptor (GIPR) expression was enhanced only by AC2 overexpression and tumor necrosis factor (TNF) expression was enhanced only by AC6 overexpression (Figure 3-2).

\section{Fsk-induced SST mRNA expression and protein production is specifically regulated by AC6 in BSMC}

In the PCR array, overexpression of AC6 enhanced Fsk-induced SST mRNA expression by 9.73 fold in BSMC, while AC2 overexpression had no effect on SST expression (Figure 3-1). $24 \mathrm{~h}$ was a reasonable starting point for measuring Fskstimulated expression of many different genes in the array, but once SST and IL-6 emerged as genes of interest with specific regulation by different $\mathrm{AC}$ isoforms, time course studies were completed to determine the optimal treatment time for further experiments. SST mRNA peaked at $3 \mathrm{~h}$ in response to $1 \mu \mathrm{M}$ Fsk (Figure 3-3).

One $\mu \mathrm{M}$ Fsk resulted in a particularly robust induction of the SST gene, so $0.3 \mu \mathrm{M}$ Fsk treatments were used in subsequent studies to avoid a saturation of the response that might prevent noticeable enhancement by $\mathrm{AC}$ overexpression. Exposure to $0.3 \mu \mathrm{M}$ Fsk for $3 \mathrm{~h}$ caused a 26.68-fold increase in SST mRNA compared to vehicle in control cells (Figure 3-4). With overexpression of AC6, the effect of Fsk was enhanced and SST mRNA was 67.48-fold above vehicle. AC2 overexpression did not alter SST when compared to control cells with native AC expression (25.74-fold over vehicle).

To determine if the increased SST mRNA in AC6 overexpressing cells results in increased protein, we used ELISA to measure SST in cell culture medium. As early as $3 \mathrm{~h}$ the effect of AC6 overexpression was observed as increased SST protein (Figure 3-5). AC6 overexpression more than doubled Fsk-induced SST production by 


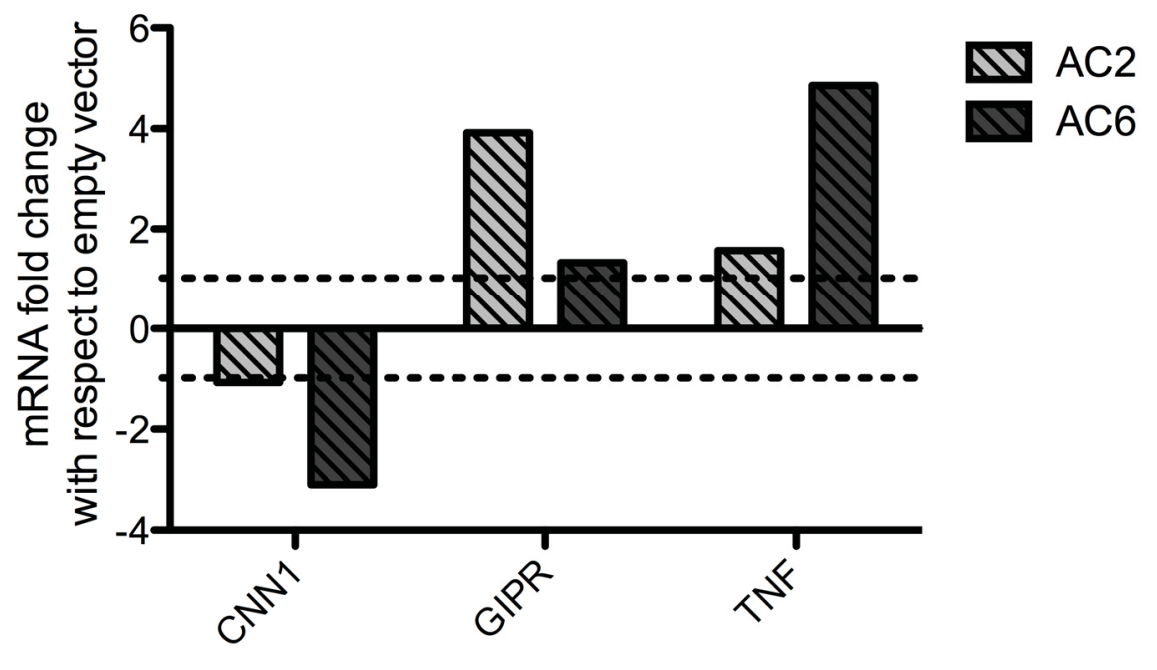

Figure 3-2. Fsk-induced gene regulation in AC overexpressing HEK-293 compared to control HEK-293

$\mathrm{RT}^{2} \mathrm{q}$ PCR arrays (SA Biosciences) were used to measure mRNA levels following $24 \mathrm{~h}$ treatment with $1 \mu \mathrm{M}$ Fsk. mRNA levels of AC overexpressing, Fsk-treated cells are expressed as fold change with respect to empty pEGFP-n1 vector (control), Fsk- treated. Calponin 1 (CNN1), Gastric inhibitory polypeptide receptor (GIPR), Tumor necrosis factor (TNF). Dashed line represents no change with respect to empty vector. Data are presented as fold change with respect to empty vector, $n=1$. 


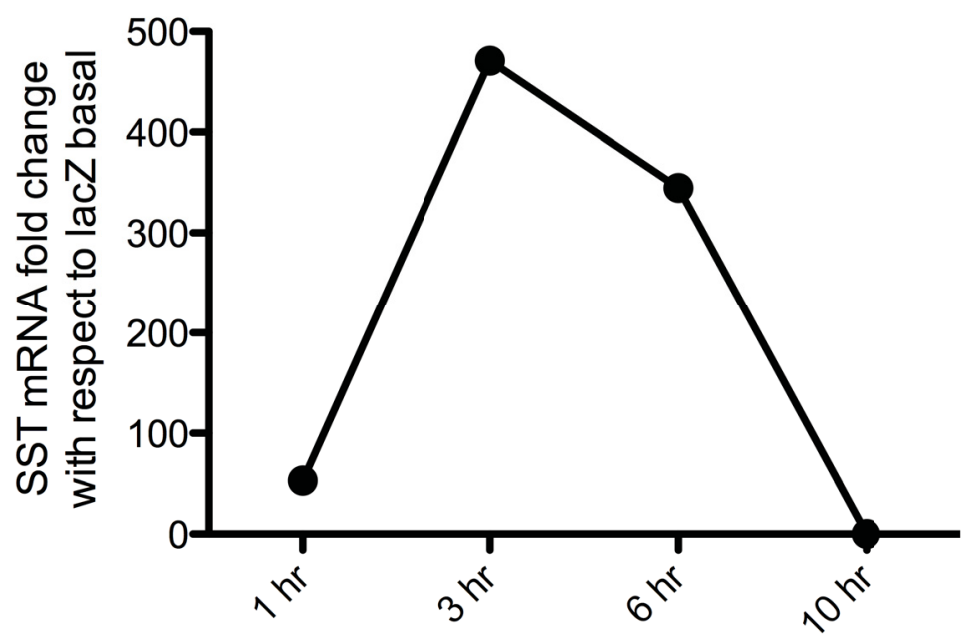

Figure 3-3. Time course of Fsk-induced SST mRNA expression

SST mRNA expression was measured by qRT-PCR in AC6 overexpressing cells exposed to $1 \mu \mathrm{M}$ Fsk for the indicated time. SST mRNA levels are expressed with respect to lacZ basal, $\mathrm{n}=1$. 


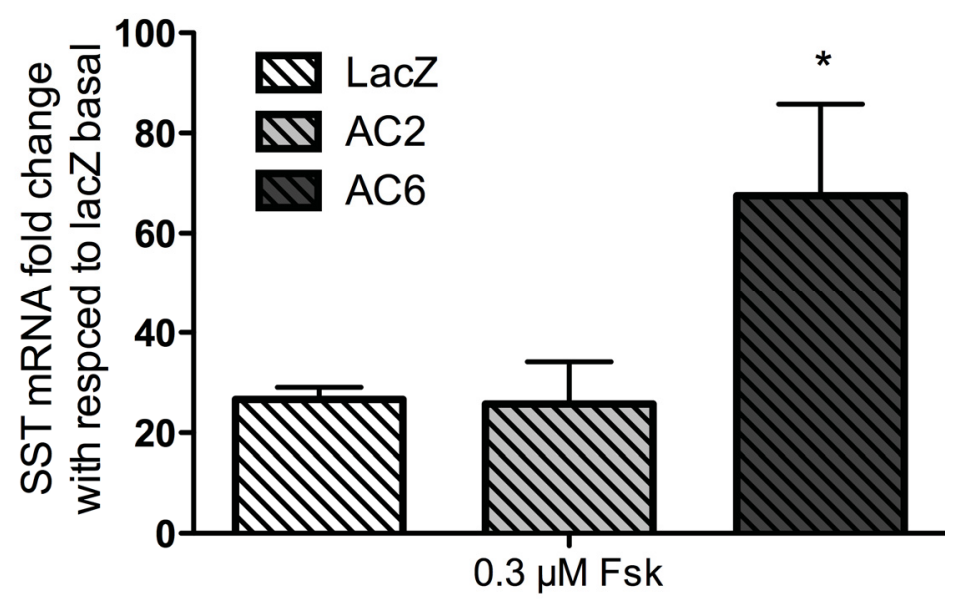

Figure 3-4. Fsk-induced SST mRNA expression in AC overexpressing BSMC qRT-PCR was used to determine SST RNA expression in BSMC treated with $0.3 \mu \mathrm{M}$ Fsk for $3 \mathrm{~h}$. Data are presented as fold change with respect to lacZ basal, mean $\pm S E M, n=3$. 


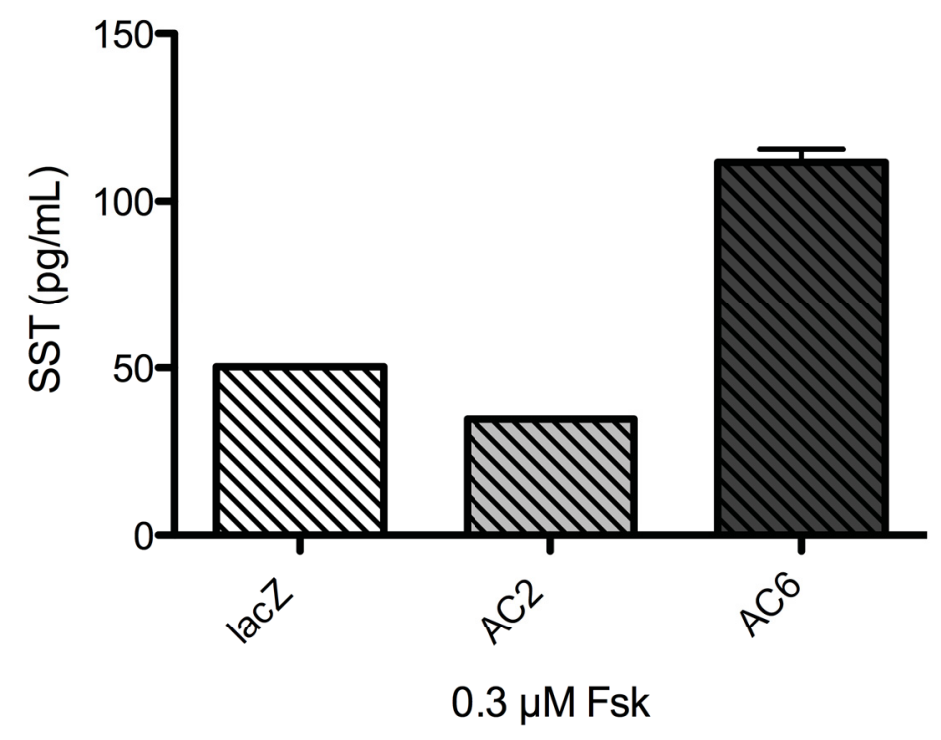

Figure 3-5. Fsk-induced SST protein production in AC overexpressing BSMC ELISA were used to measure SST secreted into culture medium by BSMC treated with $0.3 \mu \mathrm{M}$ Fsk for $3 \mathrm{~h}$. Data are presented as pg/mL SST. $\mathrm{n}=1-2$. 
$\mathrm{BSMC}$ in $3 \mathrm{~h}$, from $50.29 \mathrm{pg} / \mathrm{mL}$ to $111.69 \mathrm{pg} / \mathrm{mL}$. AC2 overexpression did not enhance SST production (Figure 3-5).

\section{Fsk-induced IL-6 mRNA expression and protein production is specifically regulated by $\mathrm{AC2}$ in BSMC}

AC2 overexpression clearly enhanced Fsk induction of IL-6 in the PCR array, but AC6 overexpression had no effect. In control BSMC, time course studies showed that IL-6 mRNA peaked at $1 \mathrm{~h}$ in response to $1 \mu \mathrm{M}$ Fsk (Figure 3-6). At $1 \mathrm{~h}, 1 \mu \mathrm{M}$ Fsk increased IL-6 mRNA in control cells by 8.16-fold (Figure 3-7A). The enhancement of IL-6 mRNA levels by AC2 overexpression was less pronounced at $1 \mathrm{~h}$ (Figure 3-7A) than $24 \mathrm{~h}$ (Figure 3-1), but since Fsk-stimulated IL-6 mRNA levels peaked at $1 \mathrm{~h}$, this time point was used in all subsequent studies. AC2 overexpression resulted in a near doubling of IL-6 mRNA compared to control cells also exposed to $1 \mu \mathrm{M}$ Fsk for $1 \mathrm{~h}$. AC6 did not alter Fsk-induced IL-6 expression compared to control cells (Figure 3-7A).

To determine if the increased IL- 6 mRNA in AC2 overexpressing cells translated to increased protein, IL-6 protein secreted into culture medium was measured by ELISA. $1 \mu \mathrm{M}$ Fsk resulted in IL-6 protein production that increased sharply between 10 and $24 \mathrm{~h}$ then continued to accumulate over time (Figure 3-8). $24 \mathrm{~h}$ was chosen as the time point for all other studies measuring IL-6 protein. Unlike mRNA, where Fsk induced a 8.16-fold increase over vehicle in control cells, IL-6 protein levels were only slightly increased by Fsk (Figure 3-7B). In control cells $24 \mathrm{~h}$ Fsk treatment increased IL-6 by $11 \%$ (from $594 \mathrm{pg} / \mathrm{mL}$ in vehicle-treated cells to $668 \mathrm{pg} / \mathrm{mL}$ in Fsk-treated). AC2 overexpression enhanced Fsk-induced IL-6 protein production to $942 \mathrm{pg} / \mathrm{mL}$. Overexpression of AC6 did not increase IL-6 over control cells, and in fact IL-6 was slightly lower in AC6 overexpressing cells $(652 \mathrm{pg} / \mathrm{mL})$ compared to control BSMC with native AC expression (Figure 3-7B).

Recent studies characterizing AC inhibitors have identified SKF-83566 as AC2selective and SQ22,536 as AC5/6-selective (Conley et al. 2013; Brand et al. 2013). We used these inhibitors as another approach to investigate the AC2-specific induction of IL-6. We pretreated BSMC with each of these inhibitors prior to $1 \mu \mathrm{M}$ Fsk treatment. Pretreatment with $30 \mu \mathrm{M}$ SKF-83566 for 20 min reduced Fsk induction of IL-6 mRNA by $48.21 \%$ (Figure 3-9). The effect of SQ22,536 pretreatment on IL-6 promoter activity was measured by luciferase assay. SQ22,536 did not significantly reduce Fsk-induced IL-6 promoter activity when the inhibitor was added at 1,3 , or $10 \mu \mathrm{M}$ for 30 min prior to Fsk treatment (Figure 3-10).

\section{IL-6 basal expression and induction by Fsk differ in BSMC from an asthmatic donor}

IL-6 levels in BALF and serum are increased in patients with asthma, and BSMC could be one contributor to raised IL-6 levels (Rincon and Irvin 2012). We 


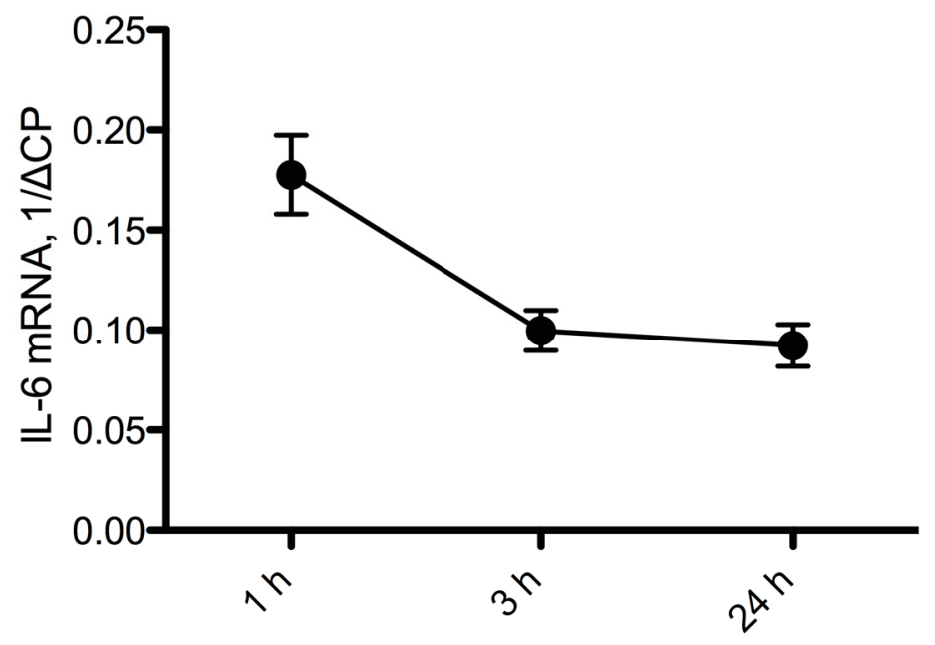

Fsk treatment time

Figure 3-6. Time course of Fsk-induced IL-6 mRNA expression

qRT-PCR was used to measure IL-6 mRNA expression in control BSMC exposed to $1 \mu \mathrm{M}$ Fsk for the indicated time. Data are expressed as the inverse of the $\mathrm{CP}$, mean \pm SEM, $\mathrm{n}=2-3$. 

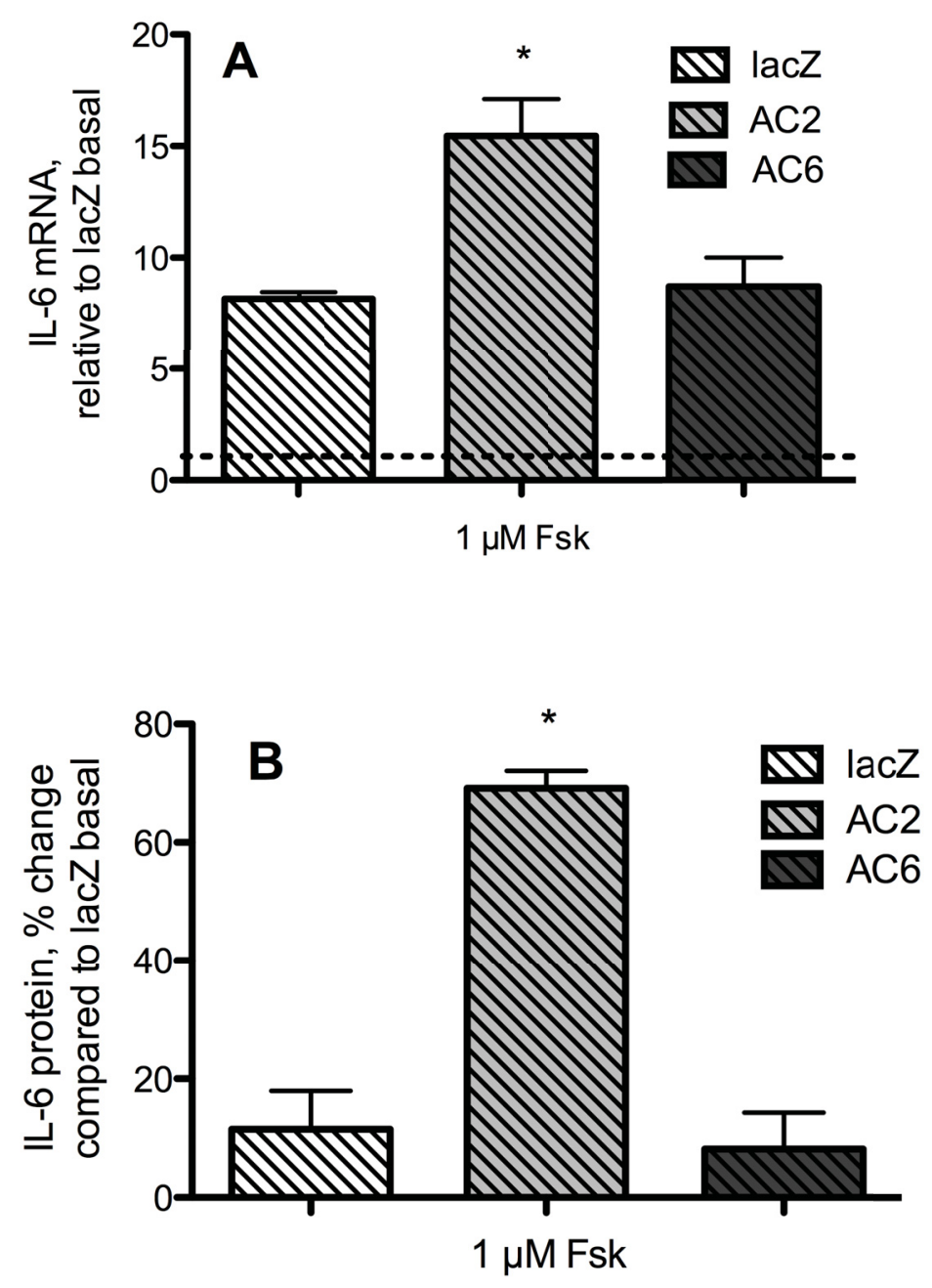

Figure 3-7. Fsk-induced IL-6 mRNA expression and protein production in AC overexpressing BSMC

(A) qRT-PCR was used to detect IL-6 mRNA levels in BSMC exposed to $1 \mu \mathrm{M}$ Fsk for $1 \mathrm{~h}$. mRNA levels of Fsk-treated cells are expressed as fold change with respect to lac Z basal, mean $\pm S E M, n=3$. Dashed line represents no change with respect to lac $Z$ basal. * indicates $\mathrm{p}<.05$ compared to lacZ. (B) ELISA were used to measure IL-6 secreted into culture medium by BSMC treated with $1 \mu \mathrm{M}$ Fsk for $24 \mathrm{~h}$. Data are presented \% change with respect to lacZ basal, mean $\pm \mathrm{SEM}, \mathrm{n}=3$. * indicates $\mathrm{p}<.05$ compared to lacZ basal. 


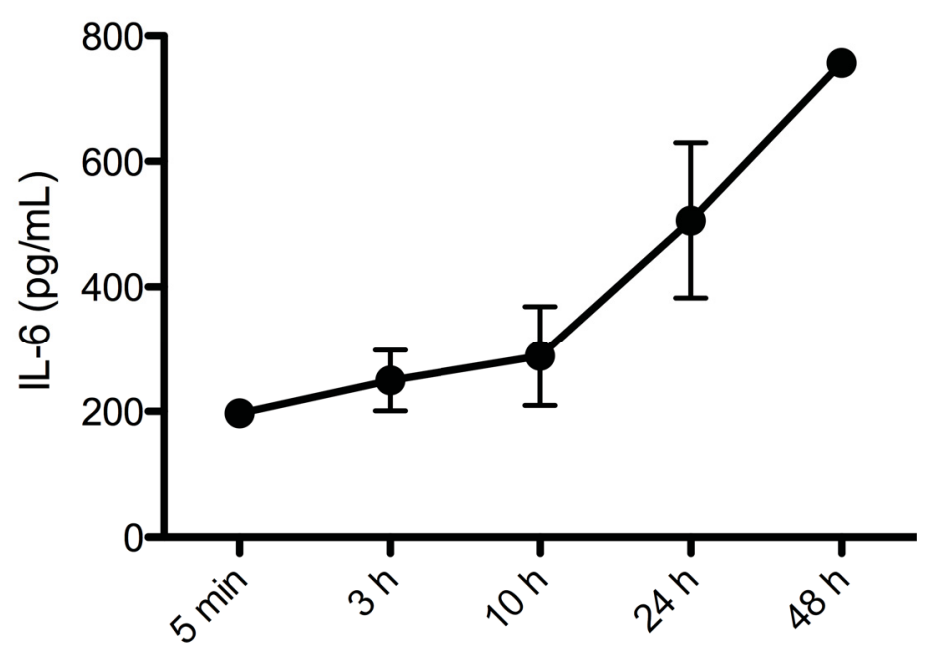

Fsk treatment time

Figure 3-8. Time course of Fsk-stimulated IL-6 protein production

ELISA were used to measure IL-6 protein in cell culture medium following exposure to $1 \mu \mathrm{M}$ Fsk for the indicated amount of time. Mean \pm SEM, $n=1-2$. 


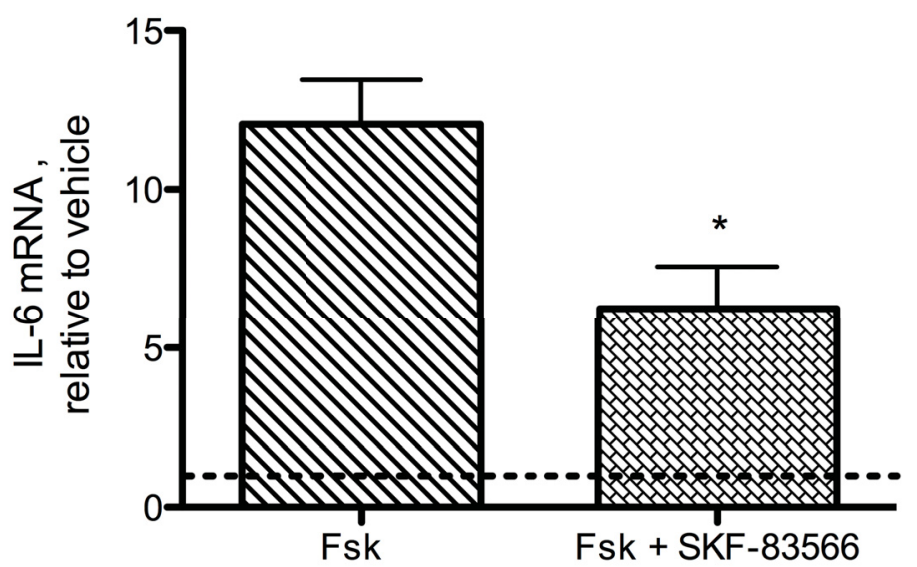

Figure 3-9. Inhibition of Fsk-induced IL-6 expression with AC2-selective inhibitor

qRT-PCR was used to determine IL-6 mRNA levels in BSMC pretreated with $30 \mu \mathrm{M}$ SKF-83566 or vehicle for $20 \mathrm{~min}$ prior to $1 \mathrm{~h}, 1 \mu \mathrm{M}$ Fsk treatment. mRNA levels are expressed relative to vehicle treated, mean $\pm S E M, n=4$. Dashed line represents no change with respect to vehicle. $*$ indicates $\mathrm{p}<.05$ compared to Fsk alone. 


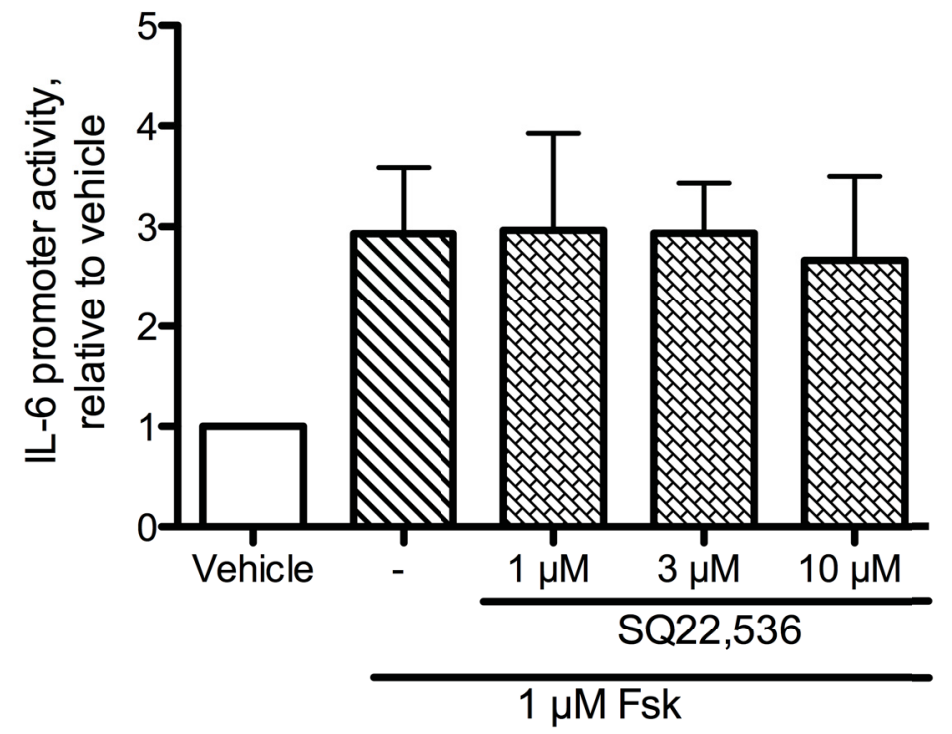

Figure 3-10. Inhibition of Fsk-induced IL-6 promoter activation with AC6selective inhibitor

Luciferase assays were used to determine IL-6 promoter activation in BSMC pretreated with the indicated concentration of SQ22,536 or vehicle for 30 min prior to $6 \mathrm{~h}, 1 \mu \mathrm{M}$ Fsk treatment. Luminescence is expressed relative to vehicle treated, mean $\pm S E M, n=4$. 
wondered if cAMP-mediated IL-6 induction differed in BSMC from an asthmatic donor compared to a non-asthmatic donor. Cells from different donors were cultured in identical growth medium with the intent to uncover any intrinsic changes in IL-6 induction pathways in asthmatic BSMC. BSMC from an asthmatic donor had basal levels of IL-6 mRNA that were 3-times higher than BSMC from a non-asthmatic donor (Figure 3-11). When BSMC from the asthmatic donor were treated with $1 \mu \mathrm{M}$ Fsk, there was no increase in IL-6 mRNA compared to those cells untreated. In non-asthmatic BSMC treated at the same time, Fsk treatment caused a 2.6-fold increase in IL-6 mRNA levels. IL- 6 expression is increased in asthmatic BSMC at rest, and AC activation by Fsk is unable to further stimulate IL-6 transcription as it does in healthy BSMC.

\section{Discussion}

A number of genes that are differentially regulated by individual $\mathrm{AC}$ isoforms in BSMC and HEK-293 were identified by PCR array (Figures 3-1 and 3-2). In BSMC IL-6 is selectively regulated by AC2 and SST is selectively regulated by AC6. AC isoform-specific enhancement of the induction of these genes results in increased protein production (Figures 3-5 and 3-7B). Basal expression of IL-6 is increased in asthmatic BSMC, and induction by Fsk is impaired (Figure 3-11).

\section{Cell-type differences}

BSMC are highly differentiated cells with unique physiological roles. To confirm that $\mathrm{AC}$ isoform-specific regulation of gene expression is a generalizable phenomenon, we also tested the less well differentiated HEK-293 cells. Both cell types have cAMP regulated genes and genes that are differentially regulated when specific AC isoforms are overexpressed (Figures 3-1 and 3-2). Interestingly, the $\mathrm{AC}$ isoforms that are predominately expressed in these cell types are similar, but the degree of compartmentation differs greatly. It is not surprising that cAMP stimulates different genes in cell types with distinct physiological roles.

One methodological difference in these studies is the mode of AC overexpression. BSMC have poor transfection efficiency, whether using lipofectamine or calcium phosphate transfection methods. Therefore adenoviral vectors were used to overexpress proteins of interest in BSMC. $\beta$ galactosidase staining indicates lacZ expression in greater than $90 \%$ of BSMC following adenoviral mediated gene transfer (Bogard et al. 2011). HEK-293 efficiently take up plasmids when transfected, but adenoviral overexpression cannot be used in HEK-293. They cannot be infected with adenovirus to overexpress AC because they are packaging cells that contain the E1 and E3 adenoviral genes, which allow adenoviral replication and lysing of the cells. 


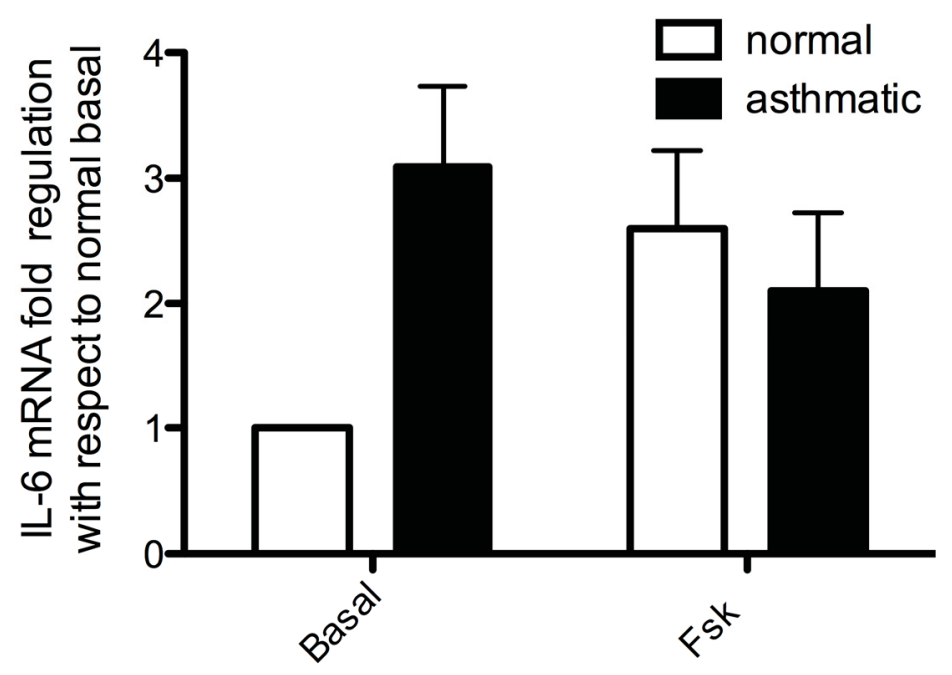

Figure 3-11. Fsk induction of IL-6 in normal and asthmatic BSMC qRT-PCR was used to detect mRNA levels in BSMC exposed to $1 \mu \mathrm{M}$ Fsk for $1 \mathrm{~h}$. mRNA levels are expressed as fold change with respect to normal basal, mean $\pm \mathrm{SEM}$, $\mathrm{n}=3$. 


\section{IL-6 and asthma pathogenesis}

The finding that AC2 specifically regulates expression of the pro-inflammatory cytokine IL-6 in BSMC is of particular interest due to its role in the pathogenesis of asthma. IL-6 is increased in the serum and BALF of asthmatic patients and is inversely correlated with lung function (Neveu et al. ; Morjaria et al. 2011). IL-6 is more than just a marker of inflammation in asthma. It can be secreted by structural cells independent of inflammation and plays a role in the development and worsening of pathological changes associated with asthma (Rincon and Irvin 2012). IL-6 has many effects in the airway. The main targets of IL-6 are immune cells, but soluble IL-6 receptors and trans-signaling allow IL-6 to mediate responses in most cell-types (Rose-John et al. 2006). IL-6 encourages the differentiation of $\mathrm{CD}^{+} \mathrm{T}$ cells to $\mathrm{Th} 2$ cells and inhibits maturation of $\mathrm{Th} 1$ cells (Diehl and Rincon 2002). This bias toward Th2 is likely involved in many pathological features of asthma including inflammation, mucus secretion, and airway hyper-responsiveness (Georas et al. 2005). IL-6 increases airway resistance and causes smooth muscle hypertrophy and hyperplasia in rodents (De et al. 1995; Rubini 2010). IL-6 is obviously important in asthma pathology, and treatment with $\beta A R$ agonists may be increasing IL-6 production through AC2-mediated signaling. A better understanding of the cAMP signaling compartments associated with regulating IL-6 expression could allow for more precisely targeted asthma therapies in the future.

We found that IL-6 expression was increased in BSMC from an asthmatic donor compared to cells from a healthy donor under basal conditions. BSMC from the asthmatic donor did not respond to Fsk with increased IL-6 expression as the normal BSMC did. The lack of Fsk response could be explained by the high basal IL-6 expression. If the pathways responsible for induction of IL-6 are constitutively active in asthmatic BSMC, Fsk may not have a further effect. Figure 3-11 represents data gathered from multiple treatments of cells isolated from 2 donors. The data here do not allow us to draw conclusions about difference between asthmatic and non-asthmatic BSMC, because they are only from a single asthmatic and a single non-asthmatic donor. IL-6 induction by cAMP signaling in BSMC from asthmatic and non-asthmatic donors should be repeated with cells from additional donors before conclusions can be made.

\section{$\mathrm{AC}$ isoform differences}

We show that genes can be regulated differently by individual $\mathrm{AC}$ isoforms. In BSMC AC2, AC4, and AC6 are endogenously expressed, and we have shown that AC2 and AC6 have distinct effects on expression of various genes when they are overexpressed and activated in BSMC. AC3 was included in our study to represent group I AC, and it was not associated with changes in Fsk-mediated gene regulation compared to control BSMC. With IL-6 found to be specifically regulated by AC2derived $\mathrm{cAMP}$, the rest of this project focused on uncovering the signaling pathways involved to determine how AC2- but not AC6-derived cAMP is associated with induction of IL-6. 


\section{CHAPTER 4. RECEPTOR MEDIATED IL-6 INDUCTION IN BSMC}

\section{Introduction}

There are over 800 genes encoding GPCR in the human genome (Fredriksson et al. 2003). Patterns of receptor expression are dependent on cell type, and most cells express many different GPCR (Hakak et al. 2003). Activities of more than 20 GPCR have been described in BSMC, with at least 5 different receptors coupling to $\mathrm{G}_{\alpha \mathrm{s}}$ (Billington and Penn 2003). Since receptors contribute to compartmentation due to differences in their associations with $\mathrm{AC}$ isoforms, we hypothesized that only a subset of receptors in BSMC would be linked to induction of IL-6. Many different receptor types have been implicated in IL-6 induction in various cell types. Among the $\mathrm{G}_{\mathrm{as}}$-coupled receptors that have been linked to IL-6 induction in other cells are $\beta_{2} \mathrm{AR}, \beta_{3} \mathrm{AR}, \mathrm{EP}_{2} \mathrm{R}$, tachykinin, CGRP, adenosine A2B, and purinergic receptors (Chen et al. 2012; Tchivileva et al. 2009; Fiebich et al. 2000; Millet and Vignery 1997; Wang et al. 2010; Zhong et al. 2005; Inoue et al. 2007). If expressed in the right signaling compartment, these $\mathrm{G}_{\mathrm{as}}$-coupled receptors have the potential to induce IL-6 in BSMC.

One way that $\mathrm{AC}$ isoforms differentially regulate cellular responses is through isoform-specific associations with receptors (Ostrom et al. 2000c). Colocalization in specialized membrane microdomains can promote specific AC-receptor interactions. Lipid rafts are specialized domains within the plasma membrane with high levels of cholesterol and sphingolipids. Caveolae represent a subset of lipid rafts distinguishable by their flask-like shape and expression of caveolin proteins. Interactions with membrane lipids or proteins allow enrichment of certain signaling molecules in lipid rafts while others are excluded (Ostrom and Insel 2004). The content of caveolae is dynamic and translocation can alter the regulation and responses of signaling molecules (Ostrom et al. 2001; Rybin et al. 2000). There are likely several mechanisms acting to target specific proteins to lipid rafts and caveolae, including protein-lipid interactions, protein-protein interactions and post-translational modifications (Moffett et al. 2000; Resh 2006; Hnasko and Lisanti 2003). Cell-specific differences in localization of receptors and $\mathrm{AC}$ have been observed for both native and overexpressed protein, providing an additional mechanism for cell-specific cAMP-mediated responses (Ostrom et al. 2000c; Ostrom et al. 2002). Colocalization in lipid rafts facilitates specific receptor-AC associations and interactions with downstream effectors and is likely responsible for some receptorspecific and AC isoform-specific cellular responses (Pike 2003).

Particular GPCR-AC associations have been described in a number of different cells, including BSMC. $\beta A R$ and AC6 are colocalized and interact in caveolae in neonatal cardiac myocytes, and a number of other receptors do not have access to AC6 in this compartment (Ostrom et al. 2000c). In BSMC AC6 and $\beta_{2} A R$ colocalize in caveolae, while $\mathrm{AC} 2$ and $\mathrm{AC} 4$ are excluded from them. $\mathrm{EP}_{2} \mathrm{R}$ colocalize and interact with AC2/AC4 outside of lipid rafts and cannot stimulate AC6 (Bogard et al. 2011). Specific GPCR-AC coupling can also occur through direct protein-protein interactions or AKAP-organized complexes (Lavine et al. 2002; Dessauer 2009). Due to specific 
localization and interactions of GPCR with AC and downstream effectors, we hypothesized that not all $\mathrm{G}_{\alpha \mathrm{s}}$ coupled receptors are associated with $\mathrm{AC} 2$ and tied to induction of IL-6 expression. We examined expression of GPCR in BSMC and used specific agonists to activate GPCR to determine which receptors stimulate IL-6 production.

\section{Results}

\section{Receptor-mediated induction of IL-6 is enhanced specifically by AC2}

After finding that direct activation of AC with Fsk resulted in an induction of IL-6 that was enhanced specifically by AC2 overexpression and not other AC isoforms, we wanted to determine if AC2 specificity persists when IL-6 is induced by activation of $\mathrm{G}_{\alpha \mathrm{s}}$-coupled receptors. We hypothesized that colocalization of receptors, $\mathrm{AC}$, and downstream effectors create distinct cAMP signaling compartments in BSMC. We have previously shown that $\mathrm{AC} 2$ and $\mathrm{EP}_{2} \mathrm{R}$ are excluded from lipid rafts in $\mathrm{BSMC}$, and that $\beta_{2} \mathrm{AR}$ are predominately localized to lipid rafts where they colocalize with AC6 (Bogard et al. 2011). These receptors have also been shown to induce IL-6 expression in other cell-types (Chen et al. 2012; Fiebich et al. 2001). Thus, we stimulated $\beta_{2} \mathrm{AR}$ with isoproterenol (Iso) or $\mathrm{EP}_{2} \mathrm{R}$ with butaprost (Buta) for $24 \mathrm{~h}$ and measured IL-6 mRNA by qRT-PCR and IL-6 secreted into culture supernatant by ELISA.

Iso and Buta were both able to induce IL-6 expression in BSMC. In control and AC overexpressing cells these agonists caused a significant increase in IL-6 mRNA (Figure 4-1). AC2 overexpression significantly enhanced IL-6 mRNA production in Iso treated cells compared to cells expressing only native levels of AC. Since the effect of Buta on IL-6 induction was highly variable, AC2's effect did not reach statistical significance. AC6 overexpression did not change RNA levels compared to control cells in response to any of the agonists tested.

Treatment with Iso or Buta also increased IL-6 protein in an AC2-specific manner (Figure 4-2). Unlike mRNA, these agonists did not significantly increase IL-6 protein compared to vehicle in control cells. Only in AC2 overexpressing cells did Iso and Buta treatments result in significant increases in IL-6 production. AC2 overexpression enhanced IL-6 protein production in response to Iso compared to control cells. As with mRNA studies, variability in the response to Buta prevented a statistically significant enhancement in $\mathrm{AC} 2$ overexpressing cells. AC6 overexpression did not alter IL-6 protein levels compared to control cells with endogenous AC expression in any of the conditions tested. 


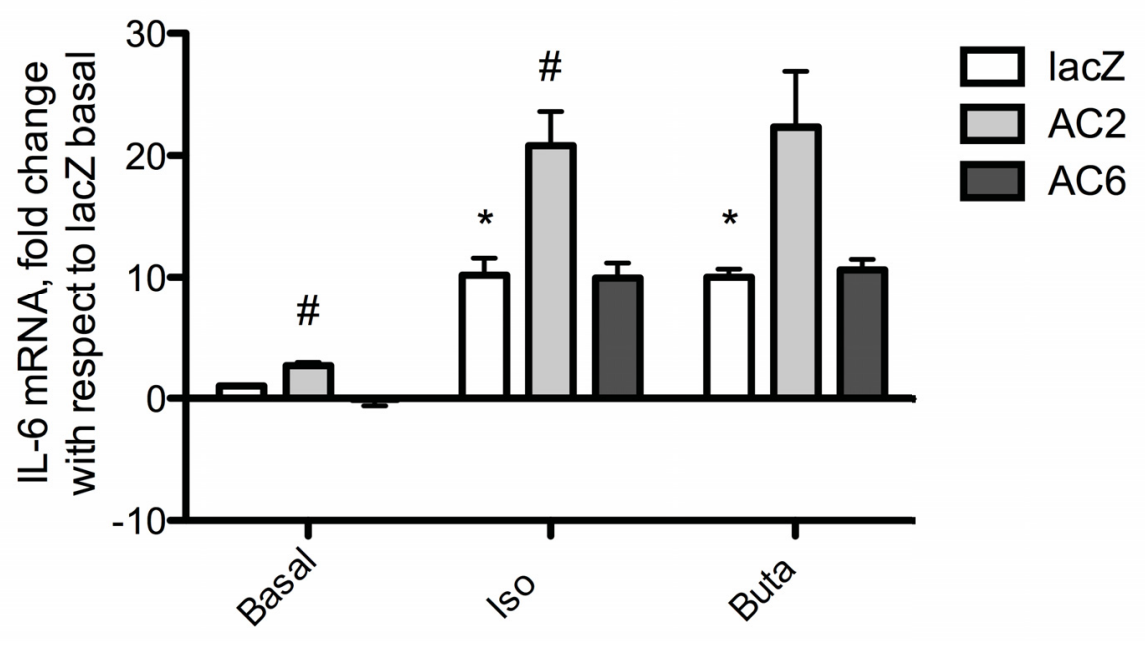

Figure 4-1. IL-6 mRNA expression in response to GPCR agonists

qRT-PCR was used to determine IL-6 mRNA levels in BSMC overexpressing lacZ, AC2 or AC6 treated with $1 \mu \mathrm{M}$ of the indicated drug for $1 \mathrm{~h}$. mRNA levels are expressed relative to lacZ basal, mean $\pm \mathrm{SEM}, \mathrm{n}=6$. * indicates $\mathrm{p}<.05$ compared to basal in lacZ, \# indicates $\mathrm{p}<.05$ in $\mathrm{AC}$ overexpressing cells compared to same treatment in control cells. 


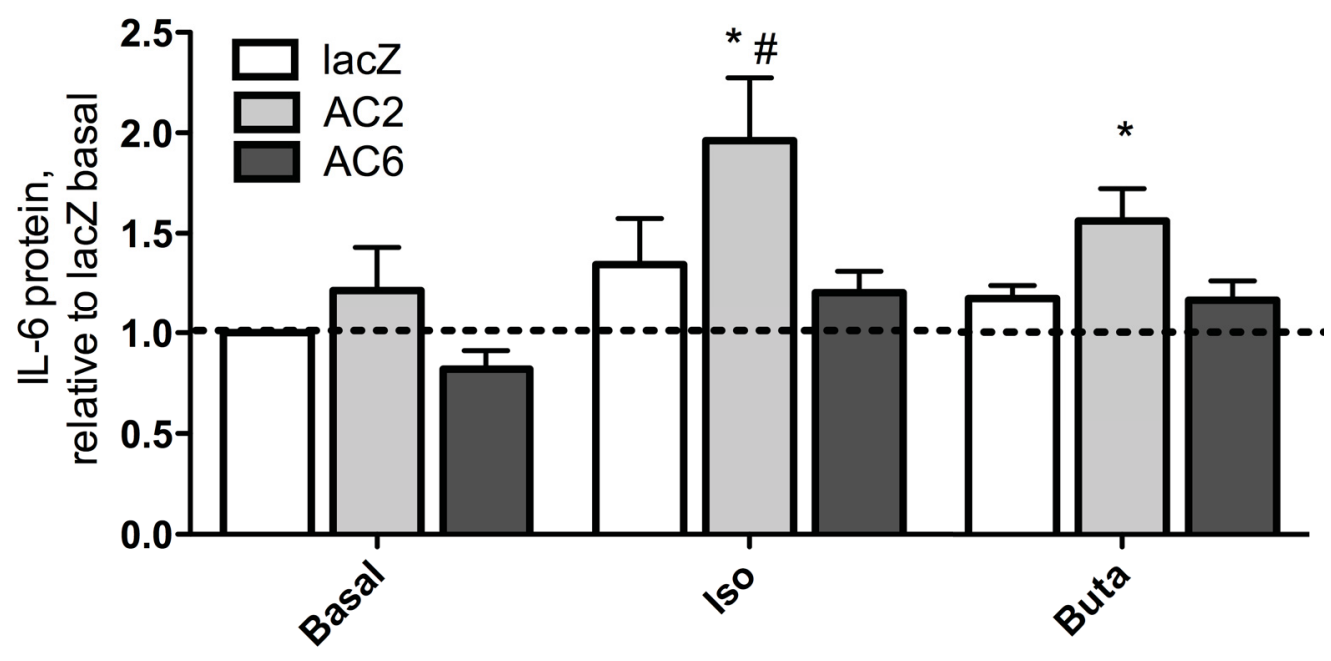

Figure 4-2. IL-6 protein production in response to GPCR agonists

ELISA were used to determine IL-6 protein levels in culture medium from BSMC overexpressing lacZ, AC2 or AC6 treated with $1 \mu \mathrm{M}$ of the indicated drug for $24 \mathrm{~h}$. Dashed line indicates no change with respect to lacZ basal. IL-6 protein is expressed relative to lacZ basal, mean $\pm \mathrm{SEM}, \mathrm{n}=3$. * indicates $\mathrm{p}<.05$ compared to lacZ basal, \# indicates $\mathrm{p}<.05$ in $\mathrm{AC}$ overexpressing cells compared to same treatment in control cells. 


\section{BSMC express several GPCR}

GPCR expression is cell-type dependent and most cells express many different receptors. The full complement of receptors expressed in BSMC has not been described previously. To better understand how AC2 specifically enhances IL-6, we wanted to know whether all $\mathrm{G}_{\alpha \mathrm{s}}$-coupled GPCR, or only a subset, are able to stimulate IL-6 gene expression. To determine which GPCR are expressed in BSMC, we used PCR arrays to probe for mRNA of 370 receptors (Table A-3). Following amplification, SYBR green melt curves were analyzed, and genes with more than one peak were excluded due to the ambiguity associated with multiple products. It is important to note that the PCR array data are qualitative in this context. Since cDNA for each receptor was amplified with different primers resulting in products of varying lengths, receptors with lower CP values are not necessarily expressed at higher levels. The PCR array served as a starting point to discover all the GPCR expressed by BSMC, but ultimately other approaches must be used to confirm functional receptor expression. mRNA was detected $(\mathrm{CP}<35)$ for 227 of the receptors tested, while mRNA was not detected $(\mathrm{CP}>35)$ for 81 receptors

(Table A-3).

The PCR array detected mRNA for $\beta_{2} \mathrm{AR}$, with an average CP of 29.90 . Amplification by $\mathrm{EP}_{2} \mathrm{R}$ primers was also apparent (CP: 26.59), but since there were multiple peaks on the melt curve the data were not conclusive, and this receptor was not included in Table A-3. $\mathrm{EP}_{2} \mathrm{R}$ expression in BSMC has been confirmed by other methods. $\mathrm{EP}_{2} \mathrm{R}$ immunoblots and the ability of Buta, an $\mathrm{EP}_{2} \mathrm{R}$-selective agonist, to increase cAMP and IL-6 (Figure 4-1) indicate that this receptor is expressed in BSMC (Bogard et al. 2011). The CP of other receptors potentially associated with IL-6 induction are listed in Table 4-1 with their predominant G-protein associations and the agonists used to investigate their activity in BSMC.

\section{Not all receptors are associated with induction of IL-6}

We chose a subset of the receptors with readily detectible mRNA and measured cAMP and IL-6 production following stimulation with specific agonists (Table 4-1). IL-6 protein in culture medium increased compared to vehicle following $24 \mathrm{~h}$ treatment with a purinergic receptor agonist, ATPYS, or adenosine receptor agonist, 5'-Nethylcarboxamidoadenosine (NECA, Figure 4-3A). Arginine vasopressin (AVP), BRL 37344 ( $\beta_{3} \mathrm{AR}$-selective agonist), $\alpha$-calcitonin gene related peptide ( $\alpha$-CGRP), glucagon, prostaglandin $\mathrm{D}_{2}\left(\mathrm{PGD}_{2}\right)$, and substance $\mathrm{P}$ did not significantly increase IL-6 secretion compared to vehicle (Figure 4-3A).

We also tested these agonists for their ability to stimulate cAMP production in BSMC. Cells were treated with the same GPCR-selective agonists for $10 \mathrm{~min}$ in the presence of a broad-spectrum PDE inhibitor (0.2 mM IBMX). ATPYS and NECA, agonists that increased IL-6 secretion, did not significantly increase global cAMP levels (Figure 4-3B). The cAMP response to NECA may be blunted by antagonism of 
Table 4-1. GPCR agonists and their targets in BSMC

\begin{tabular}{|c|c|c|c|c|c|}
\hline Agonist & Receptor & Activity & Affinity & G-protein & $\mathbf{C P}$ \\
\hline ATPYS & $\mathrm{P} 2 \mathrm{Y} 12$ & $\begin{array}{l}\text { Full } \\
\text { agonist }\end{array}$ & $5.5^{\mathrm{a}}$ & Gi/Go & 40 \\
\hline ATPYS & P2Y11 & $\begin{array}{l}\text { Full } \\
\text { agonist }\end{array}$ & $4.9-5.5^{b}$ & $\begin{array}{l}1^{\circ}: \mathrm{Gq} / \mathrm{G} 11 \\
2^{\circ}: \mathrm{Gs}\end{array}$ & 29.13 \\
\hline ATPYS & $\mathrm{P} 2 \mathrm{Y} 1$ & $\begin{array}{l}\text { Partial } \\
\text { agonist }\end{array}$ & $7.4^{\mathrm{c}}$ & $\begin{array}{l}1^{\circ}: \mathrm{Gq} / \mathrm{G} 11 \\
2^{\circ}: \mathrm{Gi} / \mathrm{Go}\end{array}$ & 34.49 \\
\hline ATPYS & $\mathrm{P} 2 \mathrm{Y} 13$ & $\begin{array}{l}\text { Full } \\
\text { Agonist }\end{array}$ & $5.5^{\mathrm{c}}$ & Gi/Go & 33.92 \\
\hline AVP & $\begin{array}{l}\text { Vasopressin } \\
\text { V1B }\end{array}$ & $\begin{array}{l}\text { Full } \\
\text { agonist }\end{array}$ & $9.0-9.5^{\mathrm{a}}$ & $\mathrm{Gq}$ & 31.00 \\
\hline AVP & $\begin{array}{l}\text { Vasopressin } \\
\text { V1A }\end{array}$ & $\begin{array}{l}\text { Full } \\
\text { agonist }\end{array}$ & $8.5-9.3^{a}$ & $\mathrm{Gq} / \mathrm{G} 11$ & 31.63 \\
\hline AVP & Vasopressin V2 & $\begin{array}{l}\text { Full } \\
\text { agonist }\end{array}$ & $7.9-9.1^{\mathrm{a}}$ & Gs & 33.55 \\
\hline AVP & OT Receptor & $\begin{array}{l}\text { Partial } \\
\text { agonist }\end{array}$ & $7.3-9.3^{\mathrm{a}}$ & Gi/Go & 27.42 \\
\hline $\begin{array}{l}\text { BRL } \\
37344\end{array}$ & $\beta 3$ Adrenergic & $\begin{array}{l}\text { Full } \\
\text { agonist }\end{array}$ & $6.4-7^{\mathrm{a}}$ & $\begin{array}{l}1^{\circ}: \text { Gs } \\
2^{\circ}: \text { Gi/Go }\end{array}$ & 30.96 \\
\hline$\alpha C G R P$ & AM1 & $\begin{array}{l}\text { Full } \\
\text { agonist }\end{array}$ & $6.0^{\mathrm{d}}$ & $\begin{array}{l}1^{\circ}: \mathrm{Gs} \\
2^{\circ}: \mathrm{Gi} / \mathrm{Go}, \\
\quad \mathrm{Gq} / \mathrm{G} 11\end{array}$ & $\begin{array}{l}\text { RAMP2 } \\
: \text { ND } \\
\text { CALCR } \\
\text { L: } 31.76\end{array}$ \\
\hline$\alpha C G R P$ & CGRP & $\begin{array}{l}\text { Full } \\
\text { agonist }\end{array}$ & $9.7-10^{\mathrm{a}}$ & $\begin{array}{l}1^{\circ}: \mathrm{Gs} \\
2^{\circ}: \mathrm{Gi} / \mathrm{Go}, \\
\quad \mathrm{Gq} / \mathrm{G} 11\end{array}$ & $\begin{array}{l}\text { RAMP1 } \\
: \text { ND } \\
\text { CALCR } \\
\text { L: } 31.76\end{array}$ \\
\hline
\end{tabular}


Table 4-1. (Continued)

\begin{tabular}{|c|c|c|c|c|c|}
\hline Agonist & Receptor & Activity & Affinity & G-protein & $\mathbf{C P}$ \\
\hline aCGRP & AM2 & $\begin{array}{l}\text { Full } \\
\text { agonist }\end{array}$ & $6.5-6.8^{\mathrm{a}}$ & $\begin{array}{l}1^{\circ}: \mathrm{Gs} \\
2^{\circ}: \mathrm{Gi} / \mathrm{Go}, \\
\mathrm{Gq} / \mathrm{G} 11\end{array}$ & $\begin{array}{l}\text { RAMP3 } \\
: \text { ND } \\
\text { CALCR } \\
\text { L: } 31.76\end{array}$ \\
\hline$\alpha C G R P$ & AMY1 & $\begin{array}{l}\text { Full } \\
\text { agonist }\end{array}$ & $8.7-10.8^{b}$ & Gs & $\begin{array}{l}\text { RAMP1 } \\
: \text { ND } \\
\text { CALCR } \\
: 36.08\end{array}$ \\
\hline$\alpha C G R P$ & AMY3 & $\begin{array}{l}\text { Full } \\
\text { agonist }\end{array}$ & $7.6-9.7^{b}$ & Gs & $\begin{array}{l}\text { RAMP3 } \\
: \text { ND } \\
\text { CALCR } \\
: 36.08\end{array}$ \\
\hline$\alpha C G R P$ & AMY2 & $\begin{array}{l}\text { Full } \\
\text { agonist }\end{array}$ & $6.2-9.7^{b}$ & Gs & $\begin{array}{l}\text { RAMP: } \\
\text { ND } \\
\text { CALCR } \\
: 36.08\end{array}$ \\
\hline$\alpha C G R P$ & $\mathrm{CT}$ & $\begin{array}{l}\text { Full } \\
\text { agonist }\end{array}$ & $6.2-8.4^{b}$ & $\begin{array}{l}1^{\circ}: \mathrm{Gs} \\
2^{\circ}: \mathrm{Gq} / \mathrm{G} 11\end{array}$ & 36.08 \\
\hline Glucagon & GLP-1 & $\begin{array}{l}\text { Full } \\
\text { agonist }\end{array}$ & $6.9-7^{\mathrm{a}}$ & Gs & ND \\
\hline Glucagon & Glucagon & $\begin{array}{l}\text { Full } \\
\text { agonist }\end{array}$ & $9.0^{b}$ & Gs & 34.68 \\
\hline NECA & A3 & $\begin{array}{l}\text { Full } \\
\text { agonist }\end{array}$ & $7.5-8.4^{\mathrm{a}}$ & Gi & 38.79 \\
\hline NECA & $\mathrm{A} 2 \mathrm{~A}$ & $\begin{array}{l}\text { Full } \\
\text { agonist }\end{array}$ & $6.9-8.7^{\mathrm{a}}$ & $\begin{array}{l}1^{\circ}: \mathrm{Gs} \\
2^{\circ}: \mathrm{Gq} / \mathrm{G} 11\end{array}$ & 32.47 \\
\hline NECA & A1 & $\begin{array}{l}\text { Full } \\
\text { agonist }\end{array}$ & $5.3-8.2^{\mathrm{a}}$ & $\begin{array}{l}1^{\circ}: \mathrm{Gi} / \mathrm{Go} \\
2^{\circ}: \mathrm{Gs} \\
\quad \mathrm{Gq} / \mathrm{G} 11\end{array}$ & 32.01 \\
\hline
\end{tabular}


Table 4-1. (Continued)

\begin{tabular}{|c|c|c|c|c|c|}
\hline Agonist & Receptor & Activity & Affinity & G-protein & $\mathbf{C P}$ \\
\hline NECA & A2B & $\begin{array}{l}\text { Full } \\
\text { agonist }\end{array}$ & $5.7-6.9^{\mathrm{a}}$ & $\begin{array}{l}1^{\circ}: \mathrm{Gs} \\
2^{\circ}: \mathrm{Gq} / \mathrm{G} 11\end{array}$ & 27.61 \\
\hline PGD2 & EP4 & $\begin{array}{l}\text { Full } \\
\text { agonist }\end{array}$ & $8.7-9^{\mathrm{a}}$ & $\begin{array}{l}1^{\circ}: \mathrm{Gs} \\
2^{\circ}: \mathrm{Gi} / \mathrm{Go}\end{array}$ & 27.71 \\
\hline PGD2 & DP1 & $\begin{array}{l}\text { Full } \\
\text { agonist }\end{array}$ & $7.8-9.2^{a}$ & Gs & 32.92 \\
\hline PGD2 & DP2 & $\begin{array}{l}\text { Full } \\
\text { agonist }\end{array}$ & $7.6-8.6^{\mathrm{a}}$ & Gi/Go & ND \\
\hline PGD2 & FP & $\begin{array}{l}\text { Full } \\
\text { agonist }\end{array}$ & $7.7^{\mathrm{a}}$ & $\begin{array}{l}1^{\circ}: \mathrm{Gq} / \mathrm{G} 11 \\
2^{\circ}: \mathrm{Gs}\end{array}$ & 28.38 \\
\hline PGD2 & EP2 & $\begin{array}{l}\text { Full } \\
\text { agonist }\end{array}$ & $5.0^{\mathrm{a}}$ & Gs & 26.59 \\
\hline PGD2 & EP1 & $\begin{array}{l}\text { Full } \\
\text { agonist }\end{array}$ & $4.7^{\mathrm{a}}$ & $\begin{array}{l}1^{\circ}: \mathrm{Gq} / \mathrm{G} 11 \\
2^{\circ}: \mathrm{Gi} / \mathrm{Go}\end{array}$ & 31.82 \\
\hline $\begin{array}{l}\text { Substance } \\
\text { P }\end{array}$ & NK1 & $\begin{array}{l}\text { Full } \\
\text { agonist }\end{array}$ & $8.5-10.3^{a}$ & $\begin{array}{l}\mathrm{Gs}, \\
\mathrm{Gq} / \mathrm{G} 11\end{array}$ & 34.49 \\
\hline $\begin{array}{l}\text { Substance } \\
\text { P }\end{array}$ & NK2 & $\begin{array}{l}\text { Full } \\
\text { agonist }\end{array}$ & $5.9-6.9^{\mathrm{a}}$ & $\begin{array}{l}\text { Gs, } \\
\text { Gq/G11 }\end{array}$ & 32.78 \\
\hline $\begin{array}{l}\text { Substance } \\
\mathbf{P}\end{array}$ & NK3 & $\begin{array}{l}\text { Full } \\
\text { agonist }\end{array}$ & $5.0-6.0^{\mathrm{a}}$ & $\mathrm{Gq} / \mathrm{G} 11$ & 32.75 \\
\hline
\end{tabular}

Notes: Affinities are listed as $\mathbf{a}, \mathrm{pKi} ; \mathbf{b}, \mathrm{pEC} 50 ; \mathbf{c}, \mathrm{pIC} 50 ; \mathbf{d}, \mathrm{pKd}$. Some receptors can couple to multiple G-proteins. $1^{\circ}$ represents the primary coupling and $2^{\circ}$ represents secondary coupling. ND (not determined) indicates genes that were not tested.

Source: Sharman JL, Benson HE, Pawson AJ, Lukito V, Mpamhanga CP, Bombail V, Davenport AP, Peters JA, Spedding M, Harmar AJ, Nc I (2013) IUPHAR-DB: updated database content and new features. Nucleic Acids Res 41 (Database issue):D1083-1088. doi:10.1093/nar/gks960 

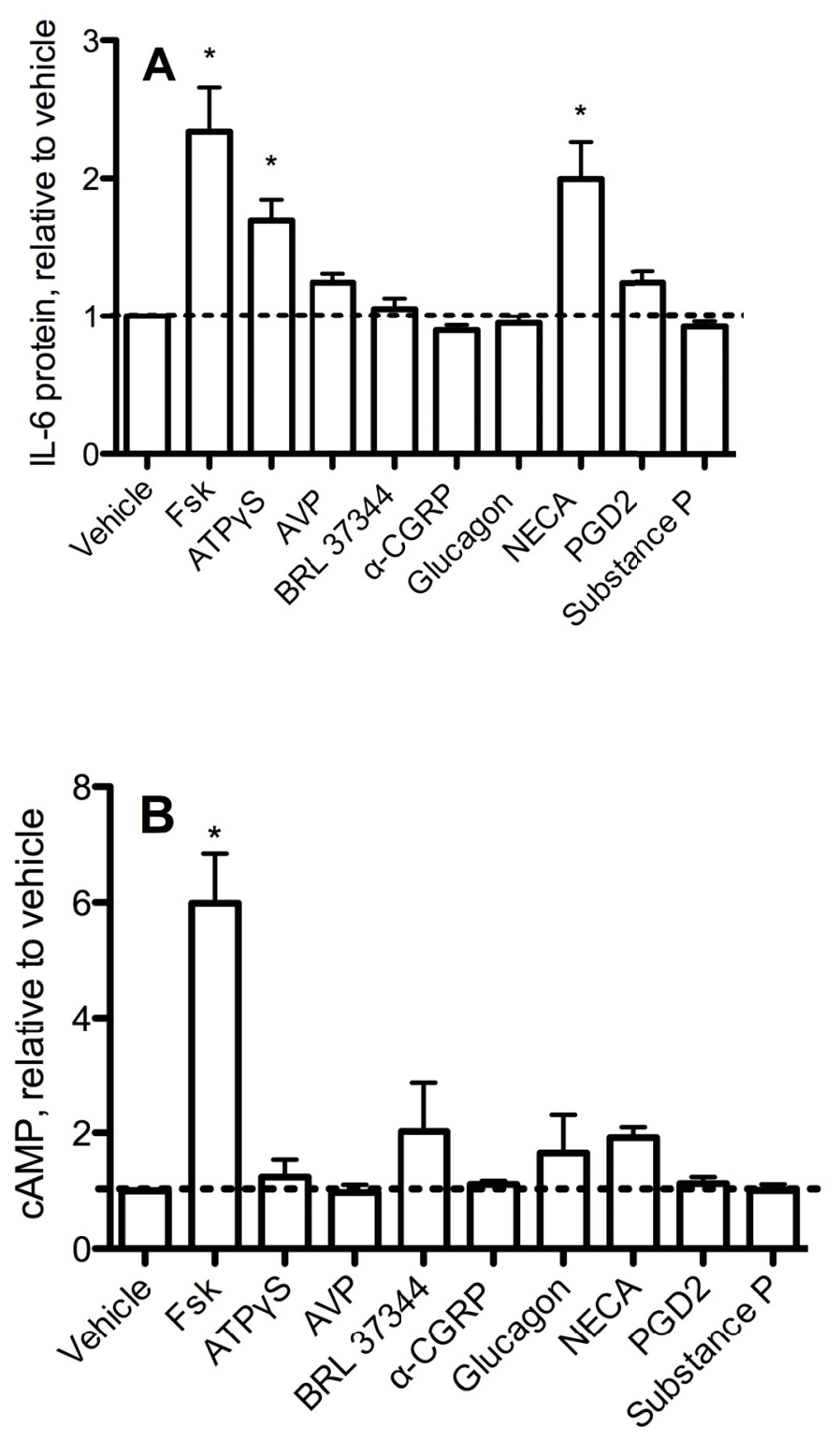

Figure 4-3. cAMP and IL-6 protein production in response to $\mathbf{G} \alpha_{s}$-coupled receptor agonists

BSMC were treated with $1 \mu \mathrm{M}$ Fsk, AVP, CGRP, glucagon, $\mathrm{PGD}_{2}$, substance P; $10 \mu \mathrm{M}$ ATPYS, BRL 37344, NECA. (A) ELISA were used to measure IL-6 secreted into culture media from cells treated with the indicated drug for $24 \mathrm{~h}$. (B) cAMP was measured by EIA in BSMC that were pretreated with $0.2 \mathrm{mM}$ IBMX prior to $10 \mathrm{~min}$ agonist. Dashed line represents no change with respect to vehicle. Data are presented as the fold response over vehicle, mean $\pm \mathrm{SEM}, \mathrm{n}=3-4$. * indicates $\mathrm{p}<.05$ compared to vehicle. 
adenosine receptors by IBMX (Daly et al. 1987). BRL 37344 and glucagon, agonists that did not increase IL-6 production, induced small but non-significant cAMP responses.

\section{IL-6 and cAMP levels are not directly correlated}

Since levels of IL-6 production did not appear to directly correlate with global cAMP levels, we further examined the correlation between cAMP and IL-6 using agonists for $\beta_{2} \mathrm{AR}$ and $\mathrm{EP}_{2} \mathrm{R}$, receptors whose expression in $\mathrm{BSMC}$ and ability to stimulate IL-6 in other cell types have been well described (Bogard et al. 2011; Raychaudhuri et al. 2010; Chen et al. 2012). Simultaneous $\mathrm{G}_{\alpha \mathrm{s}}$ and Fsk stimulation produces a synergistic cAMP response in many cell types that can aid in determining the role of this signaling pathway (Insel and Ostrom 2003; Daly et al. 1982; Darfler et al. 1982; Sutkowski et al. 1994; Ostrom et al. 2000a). AC2 overexpressing cells were treated with $0.1 \mu \mathrm{M}$ Iso or Buta alone and with concurrent Fsk $(0.1 \mu \mathrm{M})$ treatment to determine if increased cAMP always translates to increased IL-6 production. Lower concentrations of each drug were used in order to observe synergistic effects. Addition of Fsk at the time of Buta stimulation significantly increased cAMP production over agonist alone (Figure 4-4A). High variability in Iso-treated cells resulted in a non significant effect of Fsk, but addition of Fsk consistently resulted in at least doubling of cAMP compared to Iso alone. Thus, BSMC express a moderate $\mathrm{G}_{\alpha \mathrm{s}}$-Fsk synergistic effect. Using these same conditions, we found no increase in IL-6 production (Figure 4-4B). Simultaneous $\mathrm{G}_{\alpha \mathrm{s}}$ and Fsk stimulation increases cAMP substantially, but the cAMP increase does not translate to greater IL-6 expression. cAMP induces IL-6 expression in BSMC, but the levels of cAMP and IL-6 are not directly correlated.

\section{Discussion}

Agonists that do not have a significant effect on cAMP levels can induce IL-6 (Figure 4-3). Even with PDE inhibition, ATP $\gamma \mathrm{S}$ and NECA did not significantly increase cAMP production over basal levels. These two agonists can activate GPCR coupled to $\mathrm{G}_{\alpha q}$ pathways in addition to $\mathrm{G}_{\alpha \mathrm{s}}$. $\mathrm{G}_{\alpha \mathrm{q}}$ initiates protein kinase $\mathrm{C}(\mathrm{PKC})$ and mitogen activated protein kinase (MAPK) signaling pathways, which have been shown to induce IL-6 expression in other cell types. Additionally, PKC regulates AC activity of some isoforms. PKC can activate $\mathrm{AC} 2$, even without stimulation by $\mathrm{G}_{\alpha \mathrm{s}}$ or Fsk (Jacobowitz and Iyengar 1994). The ability of ATP $\gamma \mathrm{S}$ and NECA to stimulate IL-6 production without significantly increasing cAMP could be through $\mathrm{G}_{\alpha q}$ activated $\mathrm{PKC}$ directly activating AC2, or via PKC signaling pathways themselves.

Surprisingly Iso and Buta, agonists targeting receptors that are known to be expressed in BSMC and capable of inducing IL-6 expression, did not significantly increase protein production in control cells. With this known, the other agonists would have been better tested in AC2 overexpressing cells, or had their ability to induce mRNA expression measured instead of protein. We cannot be certain that the agonists that did not show increased protein are not associated with induction of IL-6 gene expression. 

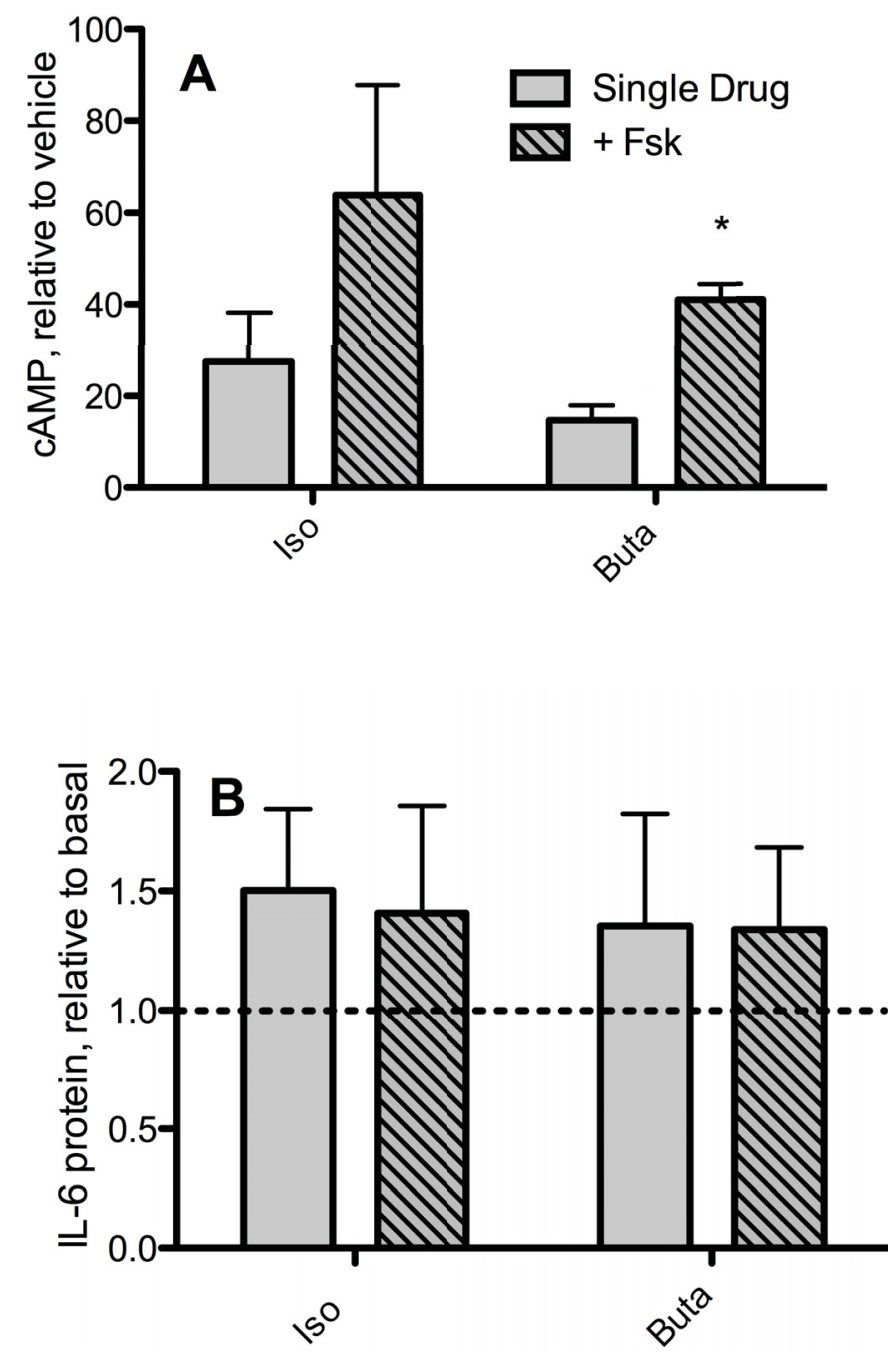

Figure 4-4. cAMP and IL-6 production in BSMC by GPCR agonists alone or with concurrent Fsk treatment

(A) Cells were treated with $0.1 \mu \mathrm{M}$ of the indicated drug with or without concurrent treatment with $0.1 \mu \mathrm{M}$ Fsk for $10 \mathrm{~min}$ in the presence of $0.2 \mathrm{mM}$ IBMX. cAMP was measured by EIA. (B) Cells were treated with $0.1 \mu \mathrm{M}$ of the indicated drug with or without concurrent treatment with $0.1 \mu \mathrm{M}$ Fsk. IL-6 in culture media was measured by ELISA following $24 \mathrm{~h}$ drug treatment. Dashed line represents no change with respect to basal. Data in both panels are presented as the fold over vehicle, mean $\pm S E M, n=3$. 
The agonists BRL-37344, substance P, and CGRP stimulate IL-6 production in other cells, but they did not increase IL-6 protein production in BSMC (Figure 4-3) (Tchivileva et al. 2009; Millet and Vignery 1997; Wang et al. 2010). There are cell-type differences in receptor-mediated induction of IL-6, likely due to differences in receptor expression, signaling intermediates and signaling compartments of cells. $\mathrm{G}_{\alpha \mathrm{s}}$-coupled receptors $\beta_{2} \mathrm{AR}$ and $\mathrm{EP}_{2} \mathrm{R}$ are linked to IL-6 induction in BSMC (Figure 4-1). As expected based on Fsk responses AC2 derived-cAMP selectively induces IL-6 in response to GPCR stimulation. Not all $\mathrm{G}_{\alpha \mathrm{s}}$ receptors are associated with induction of IL6 , likely in part due to localization that places them apart from AC2. In addition to colocalization, we found that differences in regulation, particularly AC2 activation by PKC, could be involved in some of the GPCR-mediated IL-6 induction downstream of $\mathrm{AC} 2$. 


\section{CHAPTER 5. DOWNSTREAM SIGNALING AND PROMOTER ELEMENTS ASSOCIATED WITH CAMP INDUCTION OF IL-6}

\section{Introduction}

cAMP induces IL-6 through various signaling pathways, with differences among cell types. The intermediate signaling molecules linking cAMP to IL-6 induction have not been studied in BSMC. In astrocytes, $\mathrm{PGE}_{2}$ enhances IL- 6 expression through $\mathrm{G}_{\alpha \mathrm{s}}$-coupled $\mathrm{EP}_{4}$-like receptors and p38 MAPK and PKC pathways (Fiebich et al. 2001). In chondrocytes the same stimulus regulates IL-6 expression through PKA and phosphatidylinositol 3-kinase (PI3K) pathways (Wang et al. 2010). IL-6 induction by $\beta A R$ activation in neonatal mouse cardiac fibroblasts is Epac-dependent and involves PKC $\delta$ and p38 MAPK signaling pathways (Chen et al. 2012). Since it is clear that pathways mediating cAMP induction of IL-6 are cell-type specific, we sought to determine which signaling intermediates are required for Fsk-induced IL-6 expression in BSMC.

cAMP can regulate gene expression through several different signaling pathways and a variety of transcription factors, and by the time the signal has reached the nucleus there are many opportunities for crosstalk among various signaling pathways. The IL-6 promoter contains C/EBP, CRE, NF- $\mathrm{KB}$, and $2 \mathrm{AP}-1$ sites (Dendorfer et al. 1994; Akira et al. 1990; Tanabe et al. 1988). Pathways initiated by cAMP have the potential to regulate transcription factor and cofactor binding at each of these sites. The most direct pathway linking cAMP to gene induction is through PKA phosphorylation of CREB bound to the CRE site (Gonzalez and Montminy 1989). CREB is bound to chromatin under unstimulated conditions, but PKA phosphorylation at Ser 133 leads to binding of CREB binding protein (CBP) and recruitment of transcription initiation complexes (Montminy 1997). PKA is not the only kinase that phosphorylates CREB at Ser 133, so other pathways can also regulate transcription initiation at CRE (Shaywitz and Greenberg 1999). AP-1 sites have a consensus sequence that is closely related to the CRE sequence, and CREB can also regulate transcription at these sites (Lee et al. 1987; Lamph et al. 1990). Transcription at AP-1 is also initiated by Fos-Jun dimers, which are activated by MAPK signaling cascades (Karin 1996).

$\mathrm{NF \kappa B}$ is involved in induction of many inflammatory genes. It is sequestered in

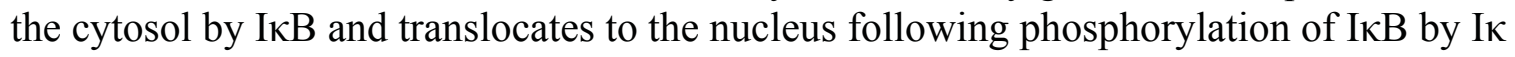

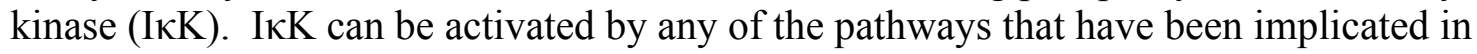
IL-6 induction in other cell types (Hayden and Ghosh 2008). The transcription factor C/EBP is also known as NF-IL-6 (Akira et al. 1990). Most cells express multiple C/EBP isoforms with varying activity. cAMP induces C/EBP translocation to the nucleus (Metz and Ziff 1991). Interestingly, asthmatic ASM do not express C/EBP $\alpha$, an inhibitory isoform (Roth et al. 2004). The C/EBP site does not appear to be involved in cAMPmediated IL-6 expression, but it may play a role in increased proliferation of ASM in asthma (Roth et al. 2004). AC isoform-specific localization and interactions are involved in establishing distinct cAMP signaling compartments that regulate precise cellular 
responses. We looked downstream of cAMP to uncover the signaling intermediates responsible for transduction of the signal from AC2 to the IL-6 promoter. We used selective cAMP agonists and inhibitors of intermediate kinases and found that PKA and Epac are activated downstream of AC2 and stimulate IL- 6 induction via CRE and AP-1 promoter elements.

\section{Results}

\section{PKA and Epac signaling induce IL-6 production}

To determine what makes AC2-derived cAMP specifically linked to induction of IL-6, we examined the downstream signaling pathways that connect cAMP signals to the nucleus. cAMP transduces signals through activation of PKA and Epac. Using specific cAMP analogs we probed for the role of each of these downstream effector molecules in regulating IL-6 levels. Exposure to $1 \mu \mathrm{M}$ 8CPT-2Me-cAMP or 8-Br-cAMP did not significantly increase IL-6 protein secretion over vehicle (Figure 5-1). The Epac selective analog, 8CPT-2Me-cAMP, significantly increased IL-6 protein at $10 \mu \mathrm{M}$ and $100 \mu \mathrm{M}$, increasing IL-6 by slightly over $50 \%$ at both concentrations. At $10 \mu \mathrm{M}$ the nonselective analog, 8-Br-cAMP, produced a similar response to 8CPT-2Me-cAMP. However, treatment with $100 \mu \mathrm{M} 8$-Br-cAMP led to a substantially larger response than the Epac selective analog, with a 4-fold increase in IL-6 protein over vehicle. The typical response to $1 \mu \mathrm{M}$ Fsk resulted in IL-6 levels greater than any 8CPT-2Me-cAMP concentration and comparable to an 8 -Br-cAMP concentration between $10 \mu \mathrm{M}$ and $100-\mu \mathrm{M}$.

To determine if PKA activity is required for induction of IL-6 in response to Fsk, we pretreated cells with the PKA inhibitor H-89. PKA inhibition reduced IL-6 produced in response to $1 \mu \mathrm{M}$ Fsk by $13.4 \%$ (Figure 5-2). When treated with selective cAMP analogs, PKA had a greater role in regulating induction of IL-6 when cAMP levels were high. Increasing the Fsk concentration to $10 \mu \mathrm{M}$ did not result in any greater reduction of IL-6 production by H-89 (Figure 5-2). $10 \mu \mathrm{M}$ Fsk produces maximal cAMP production in BSMC, but the intracellular cAMP levels are probably not as high as treatment with $100 \mu \mathrm{M} 8$ 8-Br-cAMP. Epac and PKA are responsible for cAMP-mediated induction of IL-6. PKA produces large increases in IL-6 in response to high cAMP levels, but Epac appears to regulate much of the IL-6 expression induced by Fsk treatment.

\section{Inhibition of PKC, p38 MAPK, or PI3K does not block Fsk induction of IL-6}

We used inhibitors of PKC (GF 109203X), p38 MAP kinase (SB 202190), or PI3K (wortmanin) to probe for the role of these signaling pathways, since work in other cell types implicates them in $\mathrm{G}_{\alpha \mathrm{s}}$-mediated induction of IL-6 (Fiebich et al. 2001; Wang et al. 2010). BSMC were pretreated for $1 \mathrm{~h}$ with $10 \mu \mathrm{M}$ of each inhibitor, concentrations that significantly inhibited IL-6 expression in other cell types (Fiebich et al. 2001; 


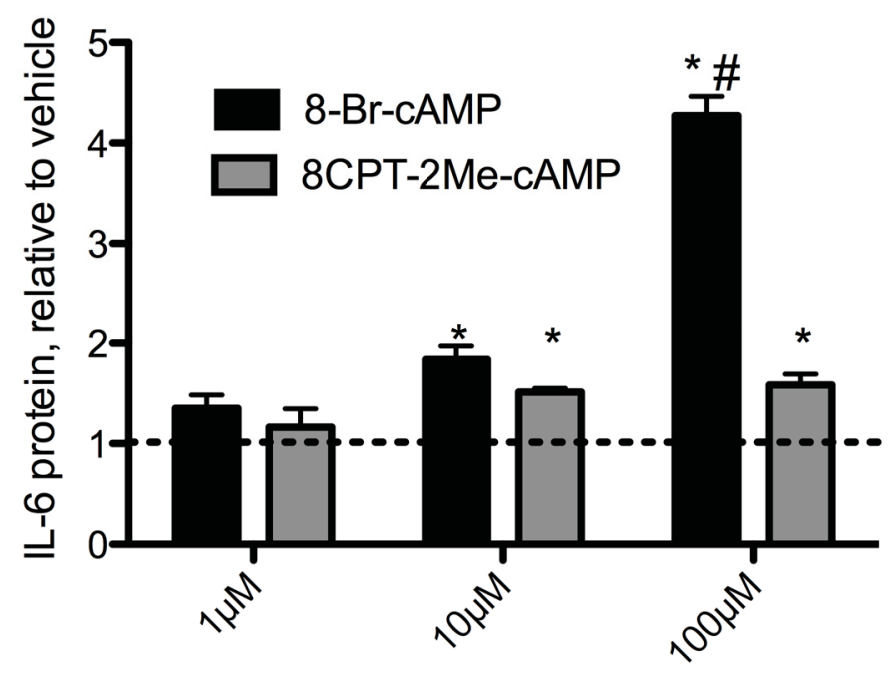

Figure 5-1. IL-6 protein production induced by cAMP analogs

ELISA were used to measure IL-6 protein in the culture medium of BSMC following $24 \mathrm{~h}$ treatment with the indicated concentration of 8-Br-cAMP or 8CPT-2Me-cAMP. Dashed line represents no change with respect to vehicle. Data are presented relative to vehicle, mean \pm SEM, $\mathrm{n}=4$. * indicates $\mathrm{p}<.05$ compared to vehicle, \# indicates $\mathrm{p}<.05$ compared to 8CPT-2Me-cAMP. 


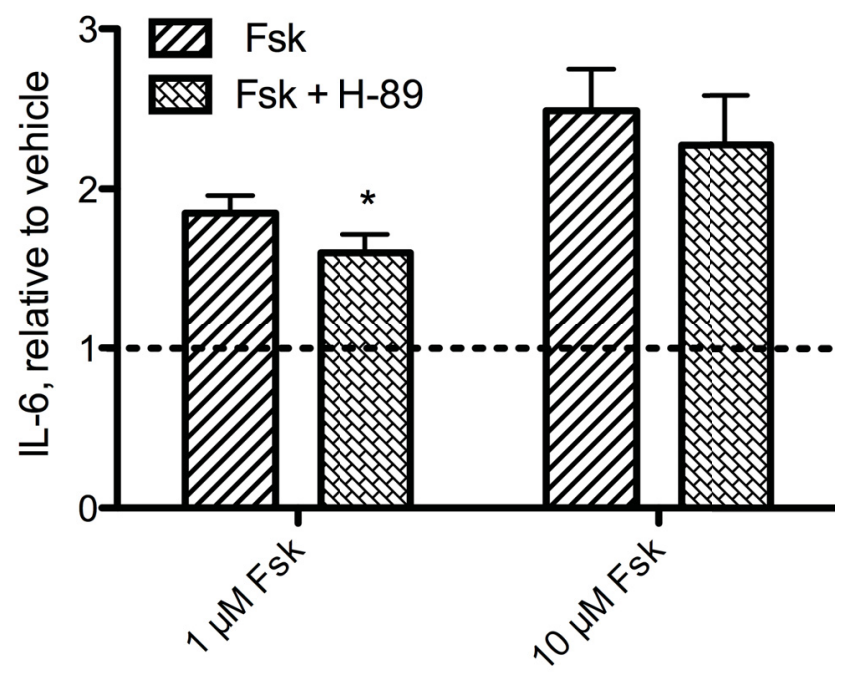

Figure 5-2. IL-6 protein production by Fsk in the presence of PKA inhibitor ELISA were used to measure IL-6 in culture supernatant of cells pretreated with $3 \mu \mathrm{M}$ $\mathrm{H}-89$ or vehicle prior to $24 \mathrm{~h} 1 \mu \mathrm{M}$ Fsk. Dashed line represents no change with respect to vehicle. Data are presented relative to vehicle, Mean \pm SEM, $n=4$. * indicates $\mathrm{p}<.05$ compared to Fsk alone. 
Wang et al. 2010). Following inhibitor pretreatment, cells were exposed to $1 \mu \mathrm{M}$ Fsk for $1 \mathrm{~h}$, and IL-6 mRNA expression was measured by qRT-PCR. None of the inhibitors tested had a significant inhibitory effect on Fsk-stimulated IL-6 expression (Figure 5-3). In fact, GF 109203X or wortmanin pretreatment tended to increase IL-6 production compared to Fsk alone (not significant). Since nonspecific effects could occur at the concentrations we chose, we tested each inhibitor at concentrations ranging from $10 \mathrm{nM}$ to $10 \mu \mathrm{M}$. There was no inhibition of Fsk-induced IL-6 expression by this range of concentrations by any of the inhibitors tested (data not shown). If anything, these inhibitors slightly increased Fsk-induced IL-6 expression. cAMP-mediated regulation of IL-6 expression may involve multiple stimulatory and inhibitory pathways with substantial cross talk and redundancy, making it difficult to unravel the steps with inhibition of individual intermediate kinases.

\section{Activation of the IL-6 promoter by Fsk requires AP-1 and CRE sites}

We used promoter analysis as an alternative approach to determine the signaling pathways involved in cAMP-mediated IL-6 expression. BSMC were transfected with vectors containing 1168 base pairs of the wild type human IL-6 promoter driving expression of the luciferase reporter gene. We also utilized individual promoter-reporter constructs that contained mutations in each of the defined promoter elements in order to test which transcriptional site(s) are required for cAMP-mediated expression of IL-6. The IL-6 promoter contains 2 AP-1 sites and 1 CRE, C/EBP and NFкB site. Site directed mutagenesis prevented transcription factor binding at the indicated site. Mutagenesis of the 3' AP-1 site increased IL-6 production in vehicle- and Fsk-treated BSMC, possibly due to regulation by a repressor at this site in the wild type promoter (Figure 5-4). Promoter activity was unchanged in the other mutant constructs under basal conditions. When stimulated with $1 \mu \mathrm{M}$ Fsk, luciferase activity was significantly reduced when the 5'AP-1 or CRE site was mutated as compared to the wild type promoter (Figure 5-4). Mutations to $\mathrm{C} / \mathrm{EBP}$ or NF- $\kappa \mathrm{B}$ did not alter the promoter's response to Fsk . For cAMP induction of IL-6 in BSMC, 5' AP-1 and CRE sites are essential but C/EBP and NFאB sites are not involved.

\section{Discussion}

At lower cAMP concentrations, Epac-selective and non-selective cAMP analogs have similar effects on IL-6 protein production (Figure 5-1). At higher cAMP concentrations, Epac does not contribute to any additional IL-6 response, but PKA signaling has a large effect on inducing IL-6 production. These data indicate a high affinity but low efficacy Epac component and a lower affinity but higher efficacy contribution from PKA activity. Stimulation by $1 \mu \mathrm{M}$ Fsk likely produces intermediate cAMP levels that act through both Epac and PKA to induce IL-6 expression. PKA inhibition with $\mathrm{H}-89$ resulted in a small reduction of IL-6 protein in response to $1 \mu \mathrm{M}$ or $10 \mu \mathrm{M}$ Fsk (Figure 5-2), consistent with dual pathways employing Epac or PKA. 


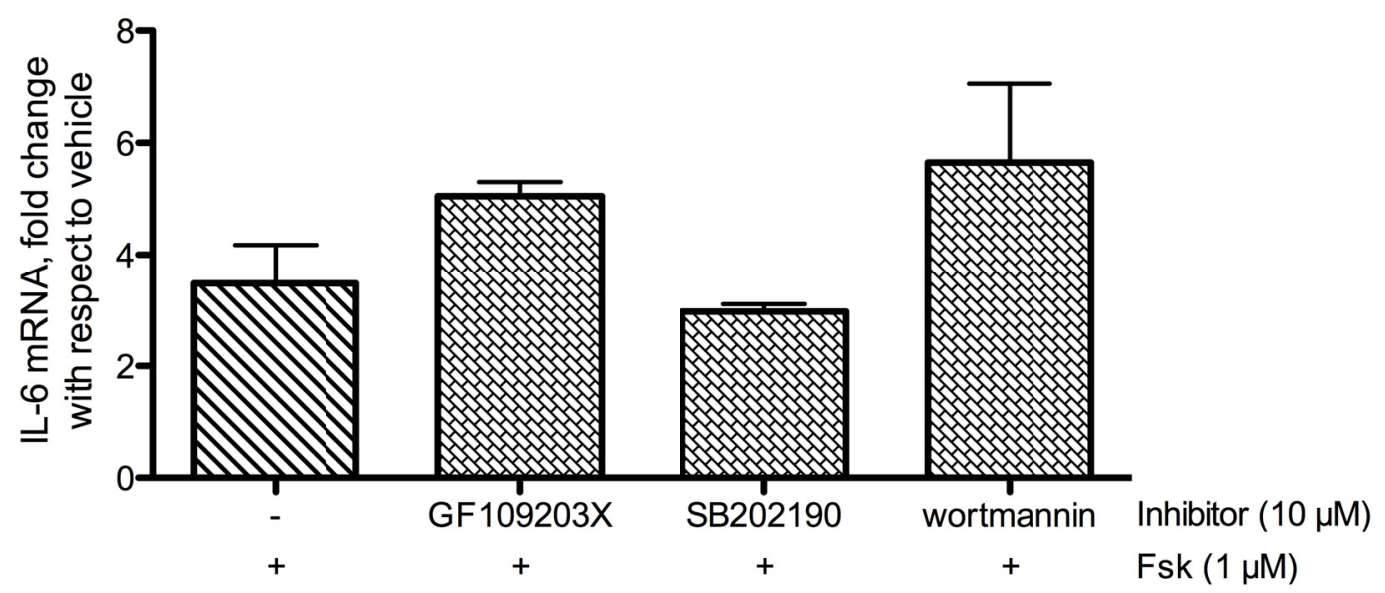

Figure 5-3. Fsk-induced IL-6 expression in the presence of kinase inhibitors qRT-PCR was used to measure IL-6 mRNA in BSMC pretreated with $10 \mu \mathrm{M}$ of the indicated inhibitor prior to $1 \mu \mathrm{M}, 1 \mathrm{~h}$ Fsk exposure. Data are expressed relative to vehicle, mean \pm SEM, $n=3-4$. 


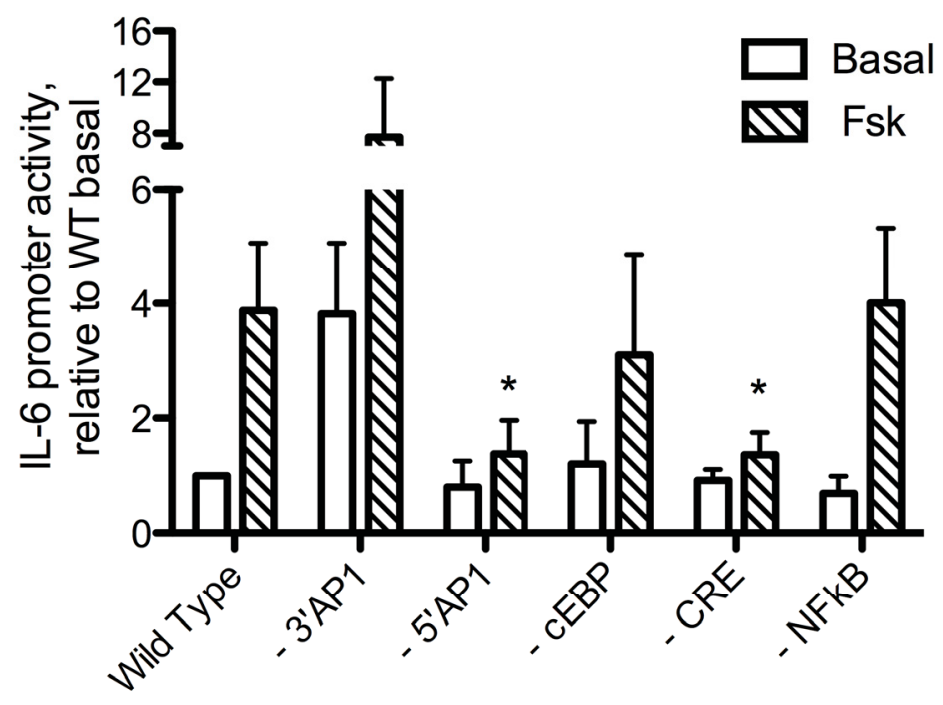

Figure 5-4. Promoter activity of wild type and mutant IL-6 promoter constructs Luciferase assays were used to measure promoter activity in BSMC transfected with wild type or mutant promoter constructs and exposed to $1 \mu \mathrm{M}$ Fsk or vehicle for $6 \mathrm{~h}$. Wild type is 1168 base pairs of the human pIL-6 promoter. Each promoter mutant construct is named by the binding site that has been ablated by site directed mutagenesis. Data are expressed as luminescence relative to wild type basal, mean \pm SEM, $n=11$. * indicates $\mathrm{p}<.05$ compared to wild type. 
The kinase inhibitors that we used to try to understand the signaling intermediates involved did not reduce Fsk-induced IL-6 expression in BSMC (Figure 5-3). It is possible that some other pathway is responsible for activating IL-6 expression, or the inhibitors that were effective in other cell types may not be appropriate for inhibiting these pathways in BSMC. By the time the signal has been passed from the plasma membrane to the nucleus there are many chances for cross-talk and redundancy of pathways, and inhibition at a single point may not be enough to prevent induction. Another pitfall is that inhibitors are not highly selective. An alternative approach to pharmacological inhibitors is RNA interference, which could produce specific inhibition without off-target effects. The poor transfection efficiency of BSMC limits the utility of RNAi in the present studies. We found that PKA and Epac are involved in cAMPmediated induction of IL-6 in BSMC, but have little insight into the downstream effectors that are involved in the signal transduction pathways leading to activation of transcription at $\mathrm{CRE}$ and $\mathrm{AP}-1$ promoter sites. 


\section{CHAPTER 6. FINAL DISCUSSION AND FUTURE DIRECTIONS}

\section{AC Isoform-Specific Responses}

This work represents the first demonstration of AC isoform-specific control of gene regulation. Previous studies have defined cAMP signaling compartments in nearmembrane events or regulation of proximal intracellular signals, but no other work of which we are aware has demonstrated cAMP compartments regulating specific genes. AC2 contributes to a signaling compartment that selectively induces IL-6 in BSMC. AC6-derived cAMP is involved in regulation of other genes, including SST, which it selectively regulates, but it does not influence IL-6 expression. Differences in AC regulation, localization, and associations with other proteins allow $\mathrm{AC}$ isoforms to create unique cAMP pools with diffusion constrained by activity of PDE. Through activation of Epac and PKA, cAMP produced by AC2 signals to the nucleus and induces IL-6 expression via CRE and AP-1 promoter elements.

Inherent differences in regulation of AC2 and AC6 could be one contributor to AC2 selective IL-6 enhancement. AC2 is activated by PKC, but AC6 is inhibited by this kinase (Jacobowitz and Iyengar 1994; Lai et al. 1999). The ability of ATPyS and NECA to induce IL-6 without significant global cAMP increase (Figure 4-3) could be explained by activation of $\mathrm{G}_{\alpha q}$-coupled receptors, which stimulate a direct PKC activation of AC2. These molecules may all exists as part of a complex with AKAP79 as recently described by Shen and Cooper (2013). Using plasma membrane targeted Epac2 FRET-based cAMP sensors along with molecular and pharmacological approaches, they showed that activation of muscarinic receptors leads to the receptor's association with AKAP79 in HEK-293 cells. AKAP79 forms a complex containing the receptor, AC2, PKC, PKA, and PDE4. This complex results in cAMP signals that are confined in space and time. Upon stimulation of the muscarinic receptor, PKC activates AC2 (a unique feature of this class of AC isoforms). The cAMP produced by AC2 is short-lived since it activates PDE4 activity via PKA, and all components are kept in close association by AKAP79 (Shen and Cooper 2013). With such tightly controlled cAMP production and degradation, downstream effectors must be in close proximity to the $\mathrm{AC}$ in this case.

It is likely that AC6 is also part of signaling complexes containing PDE. PDE4 appears to play a role in preventing cAMP produced by AC6 from inducing IL-6 expression. When we treated BSMC with the PDE4-selective inhibitor rolipram, overexpression of AC6 significantly increased IL-6 production, even at basal AC activity (with no addition of Fsk, data not shown). The AKAP gravin orchestrates a complex with PDE4 to restrict cAMP to the membrane region (Willoughby et al. 2006). Given that gravin is expressed in airway smooth muscle one might hypothesize that this complex acts to restrict the AC6 signaling compartment (Horvat et al. 2012). Further work should seek to define all the proteins associated with the $\mathrm{AC}$ isoforms natively expressed in BSMC and uncover cellular responses mediated by these different complexes. 


\section{Downstream Signaling Pathways}

Our data indicate that AC2-derived cAMP activates PKA and Epac (Figure 5-1), which are both involved in regulating IL-6 expression. At low levels of cAMP, Epac is important for transducing the signal, and at higher cAMP levels PKA plays a predominant role. These responses may reflect different sensitivities of PKA and Epac for cAMP or may also be reflective of how these two effectors participate in this specific cAMP compartment. Further studies are needed to fully understand the different roles of PKA and Epac.

Measures of bulk intracellular cAMP levels are not correlated with the amount of IL-6 produced (Figures 4-3 and 4-4). Different receptors that stimulated both cAMP production and IL- 6 did not show a clear relationship between cAMP levels and IL- 6 . In some cases, this could be explained by activation of other GPCR that stimulate $\mathrm{G}_{\alpha q}$ and PKC. However, $\mathrm{G}_{\alpha \mathrm{s}}$-Fsk synergism using only $\mathrm{G}_{\alpha \mathrm{s}}$-coupled receptors led to increased cAMP production with no further increase in IL-6 production. It is possible that there is a threshold after which additional cAMP has no ability to further increase IL-6 expression. Alternatively, a cAMP compartment model could also explain the lack of correlation with large amounts of cAMP. If cAMP is not produced in the right location, it may be unable to activate the pathways that enhance IL-6 expression. Further studies that can detect cAMP produced in distinct subcellular compartments are needed to understand if such pools of cAMP exist.

We sought to determine which downstream kinases are involved in induction of IL-6 expression with the intent of determining if they are differentially activated when AC2 or AC6 is overexpressed and activated. From the work of others it is apparent that cAMP-mediated induction of IL-6 occurs through different pathways based on the celltype and stimulus. We used pharmacological inhibitors of three kinases that are associated with cAMP-mediated induction of IL-6 in different cell-types. GF109203X (PKC inhibitor), SB202190 (p38 MAPK inhibitor), and wortmanin (PI3K inhibitor) did not inhibit IL-6 expression in response to Fsk, even when a range of concentrations was tested (Figure 5-3). These kinases that were required for IL-6 induction in other cells are not essential for Fsk-induced IL-6 production in BSMC. In fact, our data imply that these pathways may tonically inhibit the induction of IL-6. There also may be significant crosstalk among signaling pathways, so inhibition of a single intermediate does not prevent signaling to the nucleus and induction of IL-6 expression. PKC, PI3K or p38 could be part of the signaling cascade that links surface receptors to CRE and AP-1 sites of the IL-6 promoter, but other pathways predominate when one component is inhibited. A schematic of the possible signal transduction pathways connecting activation of $\mathrm{AC} 2$ to induction of IL-6 expression is shown in Figure 6-1.

\section{RNA Stabilization}

Throughout this work, we focused on AC2-specific enhancement of induction of IL-6 transcription. The ability of cAMP to regulate gene expression through CRE and 


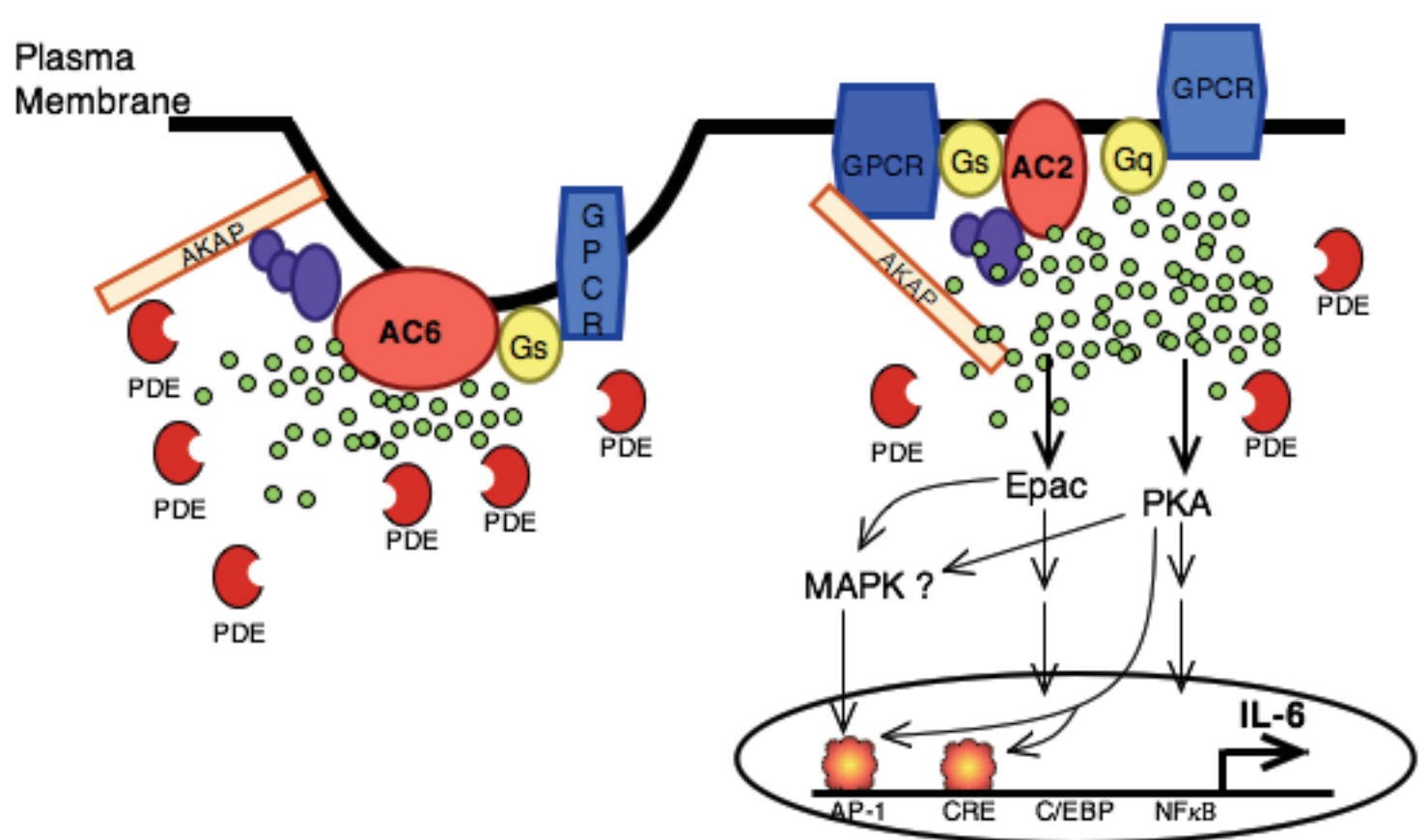

Nucleus

Figure 6-1. cAMP-mediated induction of IL-6 in BSMC

Green circles represent cAMP and purple ovals represent downstream effectors.

Following stimulation by Fsk or GPCR agonists, AC2-derived cAMP activates Epac and PKA in a signaling compartment that allows transduction of the signal to the nucleus and induction of transcription of IL-6. PDE prevent AC6-derived cAMP from activating the necessary intermediates for inducing IL-6 expression. cAMP stimulates IL-6 expression through AP-1 and CRE sites. PKA-phosphorylated CREB can activate transcription AP-1 and CRE sites, and CREB can also be phosphorylated by kinases PKC, calmodulin kinase, and RSK2 (Wen et al. 2010). Transcription at AP-1 sites can be stimulated by Fos/Jun through MAPK signaling pathways. There are likely many signaling pathways driving IL-6 expression in response to cAMP. 
AP-1 promoter elements is well established (Montminy 1997). However, careful examination of all the data from promoter activity, mRNA levels, and protein production it becomes apparent that AC2 might also act to stabilize IL-6 mRNA and not just impact promoter activation and transcription of IL-6. In control cells Fsk induces expression of IL-6 mRNA. It increases promoter activity by approximately 3 -fold, mRNA by 6.5 -fold at $1 \mathrm{~h}$, and protein by 2-fold at $24 \mathrm{~h}$ (Figures 5-4 and 3-6). When AC2 is overexpressed, IL-6 mRNA is increased 77-fold over cells with endogenous AC expression following exposure to 1- $\mu \mathrm{M}$ Fsk for $24 \mathrm{~h}$ (Figure 3-1). At $1 \mathrm{~h}$, the effect of AC2 overexpression on Fsk-induced IL-6 mRNA levels is less robust, with only a doubling of IL-6 mRNA compared to control (Figure 3-7). The effect of AC2 overexpression on IL-6 abundance is largest at the level of mRNA and has a smaller impact on promoter activation and protein production, at least with the methods we have used. cAMP certainly does induce transcription of IL-6 in BSMC, but the enhanced response with overexpression and activation of AC2 may also be due to activity that stabilizes IL-6 RNA.

For some genes cAMP has been shown to increase mRNA levels via two distinct mechanisms: increasing the rate of transcription and acting to reduce degradation of transcripts (Hod and Hanson 1988). cAMP-mediated stabilization of lactate dehydrogenase (LDH) A subunit mRNA involves binding of a complex of PKAphosphorylated proteins to the cAMP-stabilizing region (CSR) in the 3'-untranslated region. The formation of the RNA stabilizing complex requires AKAP95, so AC isoform-specific interactions are likely involved in this process too (Jungmann and Kiryukhina 2005). Future studies should determine the stability of IL-6 transcripts in control and AC overexpressing BSMC to see if AC2-derived cAMP specifically stabilizes IL-6 mRNA. Addition of a transcription inhibitor such as Actinomycin D following Fsk exposure would allow comparisons of IL-6 stability in control and AC overexpressing cells.

\section{Changes in Disease}

BSMC from an asthmatic patient had basal levels of IL-6 mRNA that were 3-times higher than BSMC from a non-asthmatic donor (Figure 3-11). When BSMC from the asthmatic donor were treated with $1 \mu \mathrm{M}$ Fsk, there was no increase in IL-6 mRNA compared to those cells untreated. In non-asthmatic BSMC treated at the same time, Fsk caused a 2.6-fold increase in IL-6 mRNA levels. There could be changes in the cAMP signaling compartments or in downstream effector pathways that result from the disease. BSMC from asthmatics are known to have changes in the expression of at least one $\mathrm{C} / \mathrm{EBP}$ isoform, which results in higher IL-6 expression in response to rhinovirus infection (Oliver et al. 2006).

While we observed differences in untreated and Fsk-induced IL-6 expression by BSMC from normal versus asthmatic donors, this study must be repeated with additional donors to confirm the differences are due to asthma. Future work should examine whether there are differences in relative expression and activity of different AC isoforms among individuals and in disease. Studies to characterize the AC isoforms expressed, 
their localization, and relative activities should be repeated in diseased BSMC to determine if there are any intrinsic differences in the cAMP signaling compartments of asthmatic BSMC.

\section{Phosphoproteomics}

The project described here has provided as many questions as answers. We are the first to show AC isoform-specific differences in regulation of gene expression, but have little insight into the mechanistic details behind this phenomenon. By the time a cAMP-mediated signal has reached the nucleus there have been many opportunities for stimulatory and inhibitory signaling and cross talk among signaling pathways, which make it difficult to trace an AC2-derived cAMP signal all the way to the IL-6 promoter. Future work will look at differences downstream of individual AC isoforms that are more proximal to cAMP production.

We are currently awaiting results from a phosphoproteomics study to identify differences in phosphorylation patterns when different $\mathrm{AC}$ isoforms are overexpressed and activated in BSMC. We used stable isotope labeling by amino acids in cell culture (SILAC) to prepare samples for quantitative phosphoproteomic analysis. Figure 6-2 illustrates a sample SILAC workflow. SILAC involves culturing two groups of cells in parallel in custom media containing isotope labeled arginine and lysine. The first group is grown in medium with unlabeled, "light" amino acids. The second group is grown in medium with arginine and lysine containing exclusively "heavy" non-radioactive ${ }^{13} \mathrm{C}$ and ${ }^{15} \mathrm{~N}$. Cells are grown in the "light" or "heavy" medium for at least 5 passages, which results in complete incorporation of these amino acids and all proteins in the cell are isotopically labeled (Ong and Mann 2006). For our study lacZ, AC2, or AC6 overexpressing BSMC grown in "light" medium were treated with $1 \mu \mathrm{M}$ Fsk for 10 min to stimulate protein phosphorylation. The corresponding cells in "heavy" medium were vehicle-treated. Following treatment, cells were lysed in a buffer containing protease and phosphatase inhibitors. Total protein in sonicated lysate was determined by BCA protein assay, and equal amounts of protein from vehicle- and Fsk- treated samples from cells overexpressing the same AC were combined. Samples were sent to the Mass Spectrometry and Proteomics Facility at Johns Hopkins for phosphoprotein enrichment and mass spectrometry analysis. Analysis of these samples will identify the phosphoproteins increased in response to Fsk treatment, and AC overexpressing cells will be compared to control BSMC. Isotope labeling allows direct comparison between vehicle and Fsk-treated cells, since the two samples are combined equally and prepared and analyzed simultaneously. Proteins in lysate of Fsk-treated cells are "light" at every lysine and arginine, so the mass to charge ratio of all trypsin-digested peptides from Fsktreated cells will be shifted to the left compared to "heavy" peptides from vehicle-treated cells (see Figure 6-2). Relative intensities of each peptide can be compared to determine whether cells with native AC expression and overexpressing AC2 or AC6 display increased phosphorylation of that protein in response to $1 \mu \mathrm{M}$ Fsk. The relative ratios of intensity for different proteins can be compared in lacZ, AC2, and AC6 overexpressing cells to determine if phosphorylation patterns differ with overexpression and activation of 


\section{Figure 6-2. SILAC experimental setup}

(a) Adaptation phase: "heavy" amino acids are incorporated over time with 100\% incorporation after five doublings. (b) Experimental phase: Following treatment cells are lysed and combined 1:1 based on total protein. Samples are fractionated and analyzed by mass spectrometry. $\mathrm{m} / \mathrm{z}$ of peptides from cells grown in "heavy" medium are shifted to the right. Relative intensity of "heavy" to "light" peak gives relative abundance of peptide in treated compared to control samples.

Reprinted with permission. Ong SE, Mann M (2006) A practical recipe for stable isotope labeling by amino acids in cell culture (SILAC). Nature protocols 1 (6):26502660. doi:10.1038/nprot.2006.427 


\section{a Adaptation phase}

Starting culture in DMEM

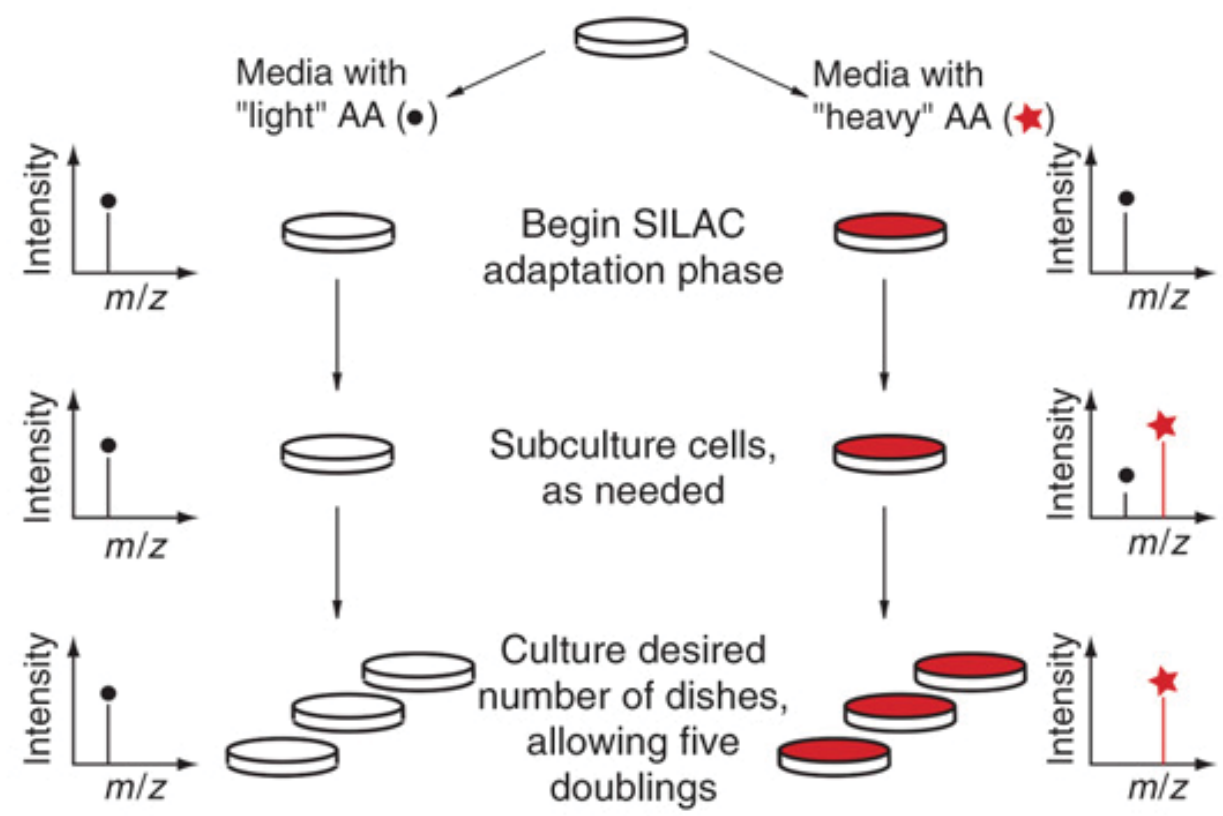

b Experiment phase

Control

State A (light • )

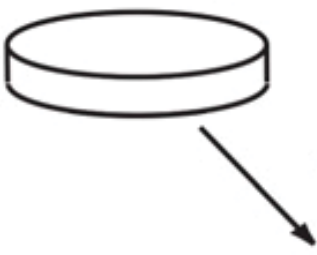

Mix cells/lysate

$1: 1$

Perturbed

State B (heavy $\star$ )

Optional protein or peptide fractionation analyze sample with mass spectrometry

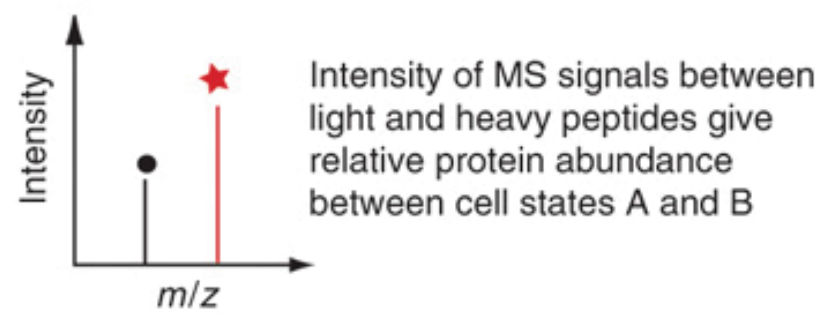


individual AC isoforms. Results from the SILAC phosphoproteomics study may provide insight into signaling intermediates activated by AC2 that could induce IL-6. Results will also be a starting point for uncovering additional $\mathrm{AC}$ isoform-specific cellular responses in BSMC.

\section{AC Isoform-Specific Regulation of Other Genes}

This project primarily focused on regulation of IL-6, but the PCR array data include other genes that are differentially regulated by individual $\mathrm{AC}$ isoforms that could be of interest in regard to cAMP signaling compartments and human health (Table A-1). With more information on the phosphorylation patterns downstream of individual AC from our phosphoproteomics study, pathways linking specific $\mathrm{AC}$ isoforms to gene regulation may become apparent. Another gene that appears to be specifically regulated by AC2-derived cAMP is prostaglandin-endoperoxide synthase 2, also known as cyclooxygenase 2 (COX-2). COX enzymes catalyze the first step in conversion of aracidonic acid to prostanoids, and are important in the pathogenesis of several inflammatory diseases (Smith et al. 2000). COX-1 is constitutively expressed, but $\mathrm{COX}-2$ is inducible, and its expression is upregulated in inflammatory diseases and many types of cancer (Vane et al. 1998). IL-1 $\beta$ is one of the proinflammatory cytokines present at higher levels in asthmatic airway, and it is one inducer of COX-2 expression in BSMC (Pang and Knox 1997). COX-2 can also be induced by $\mathrm{PGE}_{2}$, one product of COXmediated arachadonic acid metabolism, via cAMP signaling pathways (Faour et al. 2008). The pathologic consequences of COX-2 induction can be appreciated by observing the beneficial anti-inflammatory effects of COX-2 selective inhibitors such as Celecoxib (Celobrex) for treatment of chronic inflammation in patients with osteoarthritis and rheumatoid arthritis (Vane et al. 1998; FitzGerald and Patrono 2001).

Work from our lab has shown that cAMP-mediated cellular responses can be regulated by specific $\mathrm{AC}$ isoforms. This project has demonstrated that individual $\mathrm{AC}$ isoforms regulate expression of some cAMP-responsive genes. One gene that is of particular interest in the pathogenesis of asthma is the pro-inflammatory cytokine IL-6, which is induced by AC2- but not AC6-derived cAMP. $\beta A R$ agonists that are used to treat asthma may induce IL-6 via AC2 activity. As more is learned about compartmentation of cAMP signaling and attributes of $\mathrm{AC}$ isoform-specific pharmacological tools, individual AC isoforms have the potential to become therapeutic targets. Our SILAC study could add greatly to the field as it may identify specific patterns of kinase activity downstream of individual AC isoforms in BSMC. Pharmaceuticals target GPCR for treatment of many diseases through activation of cAMP signaling pathways. Receptors can be promiscuous in their coupling, allowing activation of various unintended pathways that can worsen conditions the agonists are meant to treat. Targeting AC directly would allow activation of cAMP signaling pathways without the chance of $\mathrm{G}_{\alpha \mathrm{i}}$ or $\mathrm{G}_{\alpha \mathrm{q}}$ activation. Work such as ours may allow even more precise targeting of therapeutics by identifying the individual AC isoforms and cAMP signaling compartments that contribute to beneficial responses for treatment of disease without activation of undesirable pathways and adverse effects. 


\section{LIST OF REFERENCES}

Akira S, Isshiki H, Sugita T, Tanabe O, Kinoshita S, Nishio Y, Nakajima T, Hirano T, Kishimoto T (1990) A nuclear factor for IL-6 expression (NF-IL6) is a member of a C/EBP family. Embo J 9 (6):1897-1906

Anderson GP (2006) Current issues with beta2-adrenoceptor agonists: pharmacology and molecular and cellular mechanisms. Clinical reviews in allergy \& immunology 31 (2-3):119-130. doi:10.1385/CRIAI:31:2:119

Bayewitch ML, Avidor-Reiss T, Levy R, Pfeuffer T, Nevo I, Simonds WF, Vogel Z (1998) Inhibition of adenylyl cyclase isoforms V and VI by various Gbetagamma subunits. The FASEB journal : official publication of the Federation of American Societies for Experimental Biology 12 (11):1019-1025

Benovic JL, Bouvier M, Caron MG, Lefkowitz RJ (1988) Regulation of adenylyl cyclase-coupled beta-adrenergic receptors. Annual review of cell biology 4:405428. doi:10.1146/annurev.cb.04.110188.002201

Benovic JL, Pike LJ, Cerione RA, Staniszewski C, Yoshimasa T, Codina J, Caron MG, Lefkowitz RJ (1985) Phosphorylation of the mammalian beta-adrenergic receptor by cyclic AMP-dependent protein kinase. Regulation of the rate of receptor phosphorylation and dephosphorylation by agonist occupancy and effects on coupling of the receptor to the stimulatory guanine nucleotide regulatory protein. J Biol Chem 260 (11):7094-7101

Billington CK, Penn RB (2003) Signaling and regulation of G protein-coupled receptors in airway smooth muscle. Respir Res 4 (1):2

Bogard A, Xu C, Ostrom R (2011) Human Bronchial Smooth Muscle Cells Express Adenylyl Cyclase Isoforms 2, 4, and 6 in Distinct Membrane Microdomains. J Pharmacol Exp Ther 337 (1):209-217. doi:10.1124/jpet.110.177923

Bogard AS, Adris P, Ostrom RS (2012) Adenylyl cyclase 2 selectively couples to E prostanoid type 2 receptors, whereas adenylyl cyclase 3 is not receptor-regulated in airway smooth muscle. J Pharmacol Exp Ther 342 (2):586-595. doi:10.1124/jpet.112.193425

Bol GF, Hulster A, Pfeuffer T (1997) Adenylyl cyclase type II is stimulated by PKC via C-terminal phosphorylation. Biochim Biophys Acta 1358 (3):307-313

Brand CS, Hocker HJ, Gorfe AA, Cavasotto CN, Dessauer CW (2013) Isoform Selectivity of Adenylyl Cyclase Inhibitors: Characterization of Known and Novel Compounds. J Pharmacol Exp Ther. doi:10.1124/jpet.113.208157 
Buxton IL, Brunton LL (1983) Compartments of cyclic AMP and protein kinase in mammalian cardiomyocytes. J Biol Chem 258 (17):10233-10239.

Cali JJ, Zwaagstra JC, Mons N, Cooper DM, Krupinski J (1994) Type VIII adenylyl cyclase. A Ca2+/calmodulin-stimulated enzyme expressed in discrete regions of rat brain. The Journal of biological chemistry 269 (16):12190-12195

Chen C, Du J, Feng W, Song Y, Lu Z, Xu M, Li Z, Zhang Y (2012) beta-Adrenergic receptors stimulate interleukin-6 production through Epac-dependent activation of PKCdelta/p38 MAPK signalling in neonatal mouse cardiac fibroblasts. Br J Pharmacol 166 (2):676-688. doi:10.1111/j.1476-5381.2011.01785.x

Chen J, Iyengar R (1993) Inhibition of cloned adenylyl cyclases by mutant-activated Gialpha and specific suppression of type 2 adenylyl cyclase inhibition by phorbol ester treatment. The Journal of biological chemistry 268 (17):12253-12256

Chen Y, Harry A, Li J, Smit MJ, Bai X, Magnusson R, Pieroni JP, Weng G, Iyengar R (1997) Adenylyl cyclase 6 is selectively regulated by protein kinase A phosphorylation in a region involved in Galphas stimulation. Proc Natl Acad Sci U S A 94 (25):14100-14104

Cheung D, Timmers MC, Zwinderman AH, Bel EH, Dijkman JH, Sterk PJ (1992) Longterm effects of a long-acting beta 2-adrenoceptor agonist, salmeterol, on airway hyperresponsiveness in patients with mild asthma. The New England journal of medicine 327 (17):1198-1203. doi:10.1056/NEJM199210223271703

Choi EJ, Xia Z, Storm DR (1992) Stimulation of the type III olfactory adenylyl cyclase by calcium and calmodulin. Biochemistry 31 (28):6492-6498

Conley JM, Brand CS, Bogard AS, Pratt EP, Xu R, Hockerman GH, Ostrom RS, Dessauer CW, Watts VJ (2013) Development of a high-throughput screening paradigm for the discovery of small molecule modulators of adenylyl cyclase: Identification of an adenylyl cyclase 2 inhibitor. J Pharmacol Exp Ther. doi:10.1124/jpet.113.207449

Conti MA, Adelstein RS (1981) The relationship between calmodulin binding and phosphorylation of smooth muscle myosin kinase by the catalytic subunit of $3^{\prime}: 5^{\prime}$ cAMP-dependent protein kinase. J Biol Chem 256 (7):3178-3181

Cooper PR, Kurten RC, Zhang J, Nicholls DJ, Dainty IA, Panettieri RA (2011) Formoterol and salmeterol induce a similar degree of beta2-adrenoceptor tolerance in human small airways but via different mechanisms. Br J Pharmacol 163 (3):521-532. doi:10.1111/j.1476-5381.2011.01257.x

Cumbay MG, Watts VJ (2004) Novel regulatory properties of human type 9 adenylate cyclase. J Pharmacol Exp Ther 310 (1):108-115. doi:10.1124/jpet.104.065748 
Daaka Y, Luttrell LM, Lefkowitz RJ (1997a) Switching of the coupling of the beta2adrenergic receptor to different $\mathrm{G}$ proteins by protein kinase A. Nature 390 (6655):88-91.

Daaka Y, Luttrell LM, Lefkowitz RJ (1997b) Switching of the coupling of the beta2adrenergic receptor to different $\mathrm{G}$ proteins by protein kinase A. Nature 390 (6655):88-91. doi:10.1038/36362

Daly JW, Jacobson KA, Ukena D (1987) Adenosine receptors: development of selective agonists and antagonists. Progress in clinical and biological research 230:41-63

Daly JW, Padgett W, Seamon KB (1982) Activation of cyclic AMP-generating systems in brain membranes and slices by the diterpene forskolin: augmentation of receptor-mediated responses. J Neurochem 38 (2):532-544

Darfler FJ, Mahan LC, Koachman AM, Insel PA (1982) Stimulation of forskolin of intact S49 lymphoma cells involves the nucleotide regulatory protein of adenylate cyclase. J Biol Chem 257 (20):11901-11907.

de Rooij J, Zwartkruis FJ, Verheijen MH, Cool RH, Nijman SM, Wittinghofer A, Bos JL (1998) Epac is a Rap1 guanine-nucleotide-exchange factor directly activated by cyclic AMP. Nature 396 (6710):474-477

De S, Zelazny ET, Souhrada JF, Souhrada M (1995) IL-1 beta and IL-6 induce hyperplasia and hypertrophy of cultured guinea pig airway smooth muscle cells. J Appl Physiol 78 (4):1555-1563

Dendorfer U, Oettgen P, Libermann TA (1994) Multiple regulatory elements in the interleukin- 6 gene mediate induction by prostaglandins, cyclic AMP, and lipopolysaccharide. Molecular and cellular biology 14 (7):4443-4454

Dessauer CW (2009) Adenylyl cyclase--A-kinase anchoring protein complexes: the next dimension in cAMP signaling. Mol Pharmacol 76 (5):935-941. doi:10.1124/mol.109.059345

Diehl S, Rincon M (2002) The two faces of IL-6 on Th1/Th2 differentiation. Mol Immunol 39 (9):531-536

Ding Q, Gros R, Gray ID, Taussig R, Ferguson SS, Feldman RD (2004) Raf kinase activation of adenylyl cyclases: isoform-selective regulation. Mol Pharmacol 66 (4):921-928. doi:10.1124/mol.66.4. 
Efendiev R, Samelson BK, Nguyen BT, Phatarpekar PV, Baameur F, Scott JD, Dessauer CW (2010) AKAP79 interacts with multiple adenylyl cyclase (AC) isoforms and scaffolds AC5 and -6 to alpha-amino-3-hydroxyl-5-methyl-4-isoxazolepropionate (AMPA) receptors. The Journal of biological chemistry 285 (19):14450-14458. doi:10.1074/jbc.M110.109769

Faour WH, Gomi K, Kennedy CR (2008) PGE(2) induces COX-2 expression in podocytes via the EP(4) receptor through a PKA-independent mechanism. Cell Signal 20 (11):2156-2164. doi:10.1016/j.cellsig.2008.08.007

Federman AD, Conklin BR, Schrader KA, Reed RR, Bourne HR (1992) Hormonal stimulation of adenylyl cyclase through Gi-protein beta gamma subunits. Nature 356 (6365):159-161. doi:10.1038/356159a0

Fiebich BL, Schleicher S, Butcher RD, Craig A, Lieb K (2000) The neuropeptide substance $\mathrm{P}$ activates $\mathrm{p} 38$ mitogen-activated protein kinase resulting in IL-6 expression independently from NF-kappa B. J Immunol 165 (10):5606-5611

Fiebich BL, Schleicher S, Spleiss O, Czygan M, Hull M (2001) Mechanisms of prostaglandin E2-induced interleukin-6 release in astrocytes: possible involvement of EP4-like receptors, p38 mitogen-activated protein kinase and protein kinase C. J Neurochem 79 (5):950-958

FitzGerald GA, Patrono C (2001) The coxibs, selective inhibitors of cyclooxygenase-2. N Engl J Med 345 (6):433-442. doi:10.1056/NEJM200108093450607

Fredriksson R, Lagerstrom MC, Lundin LG, Schioth HB (2003) The G-protein-coupled receptors in the human genome form five main families. Phylogenetic analysis, paralogon groups, and fingerprints. Mol Pharmacol 63 (6):1256-1272

Gao BN, Gilman AG (1991) Cloning and expression of a widely distributed (type IV) adenylyl cyclase. Proc Natl Acad Sci U S A 88:10178-10182

Gao M, Ping P, Post S, Insel PA, Tang R, Hammond HK (1998) Increased expression of adenylyl cyclase type VI proportionately increases beta-adrenergic receptorstimulated production of cAMP in neonatal rat cardiac myocytes. Proc Natl Acad Sci U S A 95 (3):1038-1043

Gao MH, Miyanohara A, Feramisco JR, Tang T (2009) Activation of PH-domain leucine-rich protein phosphatase 2 (PHLPP2) by agonist stimulation in cardiac myocytes expressing adenylyl cyclase type 6 . Biochem Biophys Res Commun 384 (2):193-198. doi:10.1016/j.bbrc.2009.04.110 
Gao MH, Tang T, Lai NC, Miyanohara A, Guo T, Tang R, Firth AL, Yuan JX, Hammond HK (2011) Beneficial effects of adenylyl cyclase type 6 (AC6) expression persist using a catalytically inactive AC6 mutant. Mol Pharmacol 79 (3):381-388. doi:10.1124/mol.110.067298

Gao X, Sadana R, Dessauer CW, Patel TB (2007) Conditional stimulation of type V and VI adenylyl cyclases by $\mathrm{G}$ protein betagamma subunits. The Journal of biological chemistry 282 (1):294-302. doi:10.1074/jbc.M607522200

Georas SN, Guo J, De Fanis U, Casolaro V (2005) T-helper cell type-2 regulation in allergic disease. Eur Respir J 26 (6):1119-1137.

doi:10.1183/09031936.05.00006005

Giembycz MA, Newton R (2006) Beyond the dogma: novel beta2-adrenoceptor signalling in the airways. The European respiratory journal : official journal of the European Society for Clinical Respiratory Physiology 27 (6):1286-1306. doi:10.1183/09031936.06.00112605

Goldie RG, Spina D, Henry PJ, Lulich KM, Paterson JW (1986) In vitro responsiveness of human asthmatic bronchus to carbachol, histamine, beta-adrenoceptor agonists and theophylline. British journal of clinical pharmacology 22 (6):669-676

Gonzalez GA, Montminy MR (1989) Cyclic AMP stimulates somatostatin gene transcription by phosphorylation of CREB at serine 133. Cell 59 (4):675-680

Gros R, Ding Q, Chorazyczewski J, Pickering JG, Limbird LE, Feldman RD (2006) Adenylyl cyclase isoform-selective regulation of vascular smooth muscle proliferation and cytoskeletal reorganization. Circ Res 99 (8):845-852. doi:10.1161/01.RES.0000245189.21703.c0

Hakak Y, Shrestha D, Goegel MC, Behan DP, Chalmers DT (2003) Global analysis of Gprotein-coupled receptor signaling in human tissues. Febs Lett 550 (1-3):11-17

Hayden MS, Ghosh S (2008) Shared principles in NF-kappaB signaling. Cell 132 (3):344-362. doi:10.1016/j.cell.2008.01.020

Hnasko R, Lisanti MP (2003) The biology of caveolae: lessons from caveolin knockout mice and implications for human disease. Molecular Interventions 3 (8):445-464

Hod Y, Hanson RW (1988) Cyclic AMP stabilizes the mRNA for phosphoenolpyruvate carboxykinase (GTP) against degradation. J Biol Chem 263 (16):7747-7752

Horvat SJ, Deshpande DA, Yan H, Panettieri RA, Codina J, Dubose TD, Jr., Xin W, Rich TC, Penn RB (2012) A-kinase anchoring proteins regulate compartmentalized cAMP signaling in airway smooth muscle. FASEB J 26 (9):3670-3679. doi:10.1096/fj.11-201020 
Inoue K, Hosoi J, Denda M (2007) Extracellular ATP has stimulatory effects on the expression and release of IL-6 via purinergic receptors in normal human epidermal keratinocytes. J Invest Dermatol 127 (2):362-371. doi:10.1038/sj.jid.5700526

Insel PA, Ostrom RS (2003) Forskolin as a tool for examining adenylyl cyclase expression, regulation, and G protein signaling. Cell Mol Neurobiol 23 (3):305314

Insel PA, Snead A, Murray F, Zhang L, Yokouchi H, Katakia T, Kwon O, Dimucci D, Wilderman A (2012) GPCR expression in tissues and cells: are the optimal receptors being used as drug targets? Br J Pharmacol 165 (6):1613-1616. doi:10.1111/j.1476-5381.2011.01434.x

Iwami G, Kawabe J, Ebina T, Cannon PJ, Homcy CJ, Ishikawa Y (1995) Regulation of adenylyl cyclase by protein kinase A. J Biol Chem 270 (21):12481-12484

Iyengar R (1993) Molecular and functional diversity of mammalian Gs-stimulated adenylyl cyclases. FASEB J 7:768-775

Jacobowitz O, Chen J, Premont RT, Iyengar R (1993) Stimulation of specific types of Gs-stimulated adenylyl cyclases by phorbol ester treatment. The Journal of biological chemistry 268 (6):3829-3832

Jacobowitz O, Iyengar R (1994) Phorbol ester-induced stimulation and phosphorylation of adenylyl cyclase 2. Proc Natl Acad Sci U S A 91 (22):10630-10634

James AL, Elliot JG, Jones RL, Carroll ML, Mauad T, Bai TR, Abramson MJ, McKay KO, Green FH (2012) Airway smooth muscle hypertrophy and hyperplasia in asthma. Am J Respir Crit Care Med 185 (10):1058-1064.

doi:10.1164/rccm.201110-1849OC

Johnson PR, Burgess JK, Underwood PA, Au W, Poniris MH, Tamm M, Ge Q, Roth M, Black JL (2004) Extracellular matrix proteins modulate asthmatic airway smooth muscle cell proliferation via an autocrine mechanism. J Allergy Clin Immunol 113 (4):690-696. doi:10.1016/j.jaci.2003.12.312

Johnston SL, Edwards MR (2009) Mechanisms of adverse effects of \{beta\}-agonists in asthma. Thorax 64 (9):739-741. doi:10.1136/thx.2009.119230

Jungmann RA, Kiryukhina O (2005) Cyclic AMP and AKAP-mediated targeting of protein kinase A regulates lactate dehydrogenase subunit A mRNA stability. J Biol Chem 280 (26):25170-25177. doi:10.1074/jbc.M502514200 
Kapiloff MS, Piggott LA, Sadana R, Li J, Heredia LA, Henson E, Efendiev R, Dessauer CW (2009) An adenylyl cyclase-mAKAPbeta signaling complex regulates cAMP levels in cardiac myocytes. J Biol Chem 284 (35):23540-23546.

doi:10.1074/jbc.M109.030072

Karin M (1996) The regulation of AP-1 activity by mitogen-activated protein kinases. Philosophical transactions of the Royal Society of London Series B, Biological sciences 351 (1336):127-134. doi:10.1098/rstb.1996.0008

Katsushika S, Chen L, Kawabe J, Nilakantan R, Halnon NJ, Homcy CJ, Ishikawa Y (1992) Cloning and characterization of a sixth adenylyl cyclase isoform: types V and VI constitute a subgroup within the mammalian adenylyl cyclase family. Proc Natl Acad Sci U S A 89 (18):8774-8778

Kawabe J, Iwami G, Ebina T, Ohno S, Katada T, Ueda Y, Homcy CJ, Ishikawa Y (1994) Differential activation of adenylyl cyclase by protein kinase $\mathrm{C}$ isoenzymes. The Journal of biological chemistry 269 (24):16554-16558

Keely SL (1977) Activation of cAMP-dependent protein kinase without a corresponding increase in phosphorylase activity. Research communications in chemical pathology and pharmacology 18 (2):283-290

Keely SL (1979) Prostaglandin E1 activation of heart cAMP-dependent protein kinase: apparent dissociation of protein kinase activation from increases in phosphorylase activity and contractile force. Mol Pharmacol 15 (2):235-245

Knox AJ, Tattersfield AE (1995) Airway smooth muscle relaxation. Thorax 50 (8):894901

Kume H, Hall IP, Washabau RJ, Takagi K, Kotlikoff MI (1994) Beta-adrenergic agonists regulate $\mathrm{KCa}$ channels in airway smooth muscle by cAMP-dependent and independent mechanisms. J Clin Invest 93 (1):371-379

Lai HL, Lin TH, Kao YY, Lin WJ, Hwang MJ, Chern Y (1999) The N terminus domain of type VI adenylyl cyclase mediates its inhibition by protein kinase C. Mol Pharmacol 56 (3):644-650

Lai HL, Yang TH, Messing RO, Ching YH, Lin SC, Chern Y (1997) Protein kinase C inhibits adenylyl cyclase type VI activity during desensitization of the A2aadenosine receptor-mediated cAMP response. J Biol Chem 272 (8):4970-4977

Lamph WW, Dwarki VJ, Ofir R, Montminy M, Verma IM (1990) Negative and positive regulation by transcription factor cAMP response element-binding protein is modulated by phosphorylation. Proc Natl Acad Sci U S A 87 (11):4320-4324 
Lavine N, Ethier N, Oak JN, Pei L, Liu F, Trieu P, Rebois RV, Bouvier M, Hebert TE, Van Tol HH (2002) G protein-coupled receptors form stable complexes with inwardly rectifying potassium channels and adenylyl cyclase. The Journal of biological chemistry 277 (48):46010-46019. doi:10.1074/jbc.M205035200

Lee W, Haslinger A, Karin M, Tjian R (1987) Activation of transcription by two factors that bind promoter and enhancer sequences of the human metallothionein gene and SV40. Nature 325 (6102):368-372. doi:10.1038/325368a0

Lohse MJ, Benovic JL, Caron MG, Lefkowitz RJ (1990) Multiple pathways of rapid beta 2-adrenergic receptor desensitization. Delineation with specific inhibitors. The Journal of biological chemistry 265 (6):3202-3211

Martin JG, Jo T (2008) Genetic differences in airway smooth muscle function. Proc Am Thorac Soc 5 (1):73-79. doi:10.1513/pats.200706-069VS

Matsumoto H, Moir LM, Oliver BG, Burgess JK, Roth M, Black JL, McParland BE (2007) Comparison of gel contraction mediated by airway smooth muscle cells from patients with and without asthma. Thorax 62 (10):848-854. doi:10.1136/thx.2006.070474

Metz R, Ziff E (1991) cAMP stimulates the C/EBP-related transcription factor rNFIL-6 to trans-locate to the nucleus and induce c-fos transcription. Genes Dev 5 (10):1754-1766

Mika D, Leroy J, Vandecasteele G, Fischmeister R (2012) PDEs create local domains of cAMP signaling. J Mol Cell Cardiol 52 (2):323-329. doi:10.1016/j.yjmcc.2011.08.016

Millet I, Vignery A (1997) The neuropeptide calcitonin gene-related peptide inhibits TNF-alpha but poorly induces IL-6 production by fetal rat osteoblasts. Cytokine 9 (12):999-1007. doi:10.1006/cyto.1997.0245

Moffett S, Brown DA, Linder ME (2000) Lipid-dependent targeting of G proteins into rafts. J Biol Chem 275 (3):2191-2198

Montminy M (1997) Transcriptional regulation by cyclic AMP. Annu Rev Biochem 66:807-822

Morjaria JB, Babu KS, Vijayanand P, Chauhan AJ, Davies DE, Holgate ST (2011) Sputum IL-6 concentrations in severe asthma and its relationship with FEV1. Thorax 66 (6):537. doi:10.1136/thx.2010.136523

Murthy KS (2001) cAMP inhibits IP(3)-dependent $\mathrm{Ca}(2+)$ release by preferential activation of cGMP-primed PKG. American journal of physiology Gastrointestinal and liver physiology 281 (5):G1238-1245 
National Asthma E, Prevention P (2002) National Asthma Education and Prevention Program. Expert Panel Report: Guidelines for the Diagnosis and Management of Asthma Update on Selected Topics--2002. J Allergy Clin Immunol 110 (5 Suppl):S141-219

Naureckas ET, Ndukwu IM, Halayko AJ, Maxwell C, Hershenson MB, Solway J (1999) Bronchoalveolar lavage fluid from asthmatic subjects is mitogenic for human airway smooth muscle. Am J Respir Crit Care Med 160 (6):2062-2066. doi:10.1164/ajrccm.160.6.9903131

Neveu WA, Allard JL, Raymond DM, Bourassa LM, Burns SM, Bunn JY, Irvin CG, Kaminsky DA, Rincon M (2010) Elevation of IL-6 in the allergic asthmatic airway is independent of inflammation but associates with loss of central airway function. Respir Res 11:28. doi:10.1186/1465-9921-11-28

Oliver BG, Johnston SL, Baraket M, Burgess JK, King NJ, Roth M, Lim S, Black JL (2006) Increased proinflammatory responses from asthmatic human airway smooth muscle cells in response to rhinovirus infection. Respiratory Research 7:71. doi:10.1186/1465-9921-7-71

Onda T, Hashimoto Y, Nagai M, Kuramochi H, Saito S, Yamazaki H, Toya Y, Sakai I, Homcy CJ, Nishikawa K, Ishikawa Y (2001) Type-specific regulation of adenylyl cyclase. Selective pharmacological stimulation and inhibition of adenylyl cyclase isoforms. J Biol Chem 276 (51):47785-47793. doi:10.1074/jbc.M107233200

Ong SE, Mann M (2006) A practical recipe for stable isotope labeling by amino acids in cell culture (SILAC). Nature protocols 1 (6):2650-2660. doi:10.1038/nprot.2006.427

Ostrom RS, Bogard AS, Gros R, Feldman RD (2012) Choreographing the adenylyl cyclase signalosome: sorting out the partners and the steps. Naunyn Schmiedebergs Arch Pharmacol 385 (1):5-12. doi:10.1007/s00210-011-0696-9

Ostrom RS, Gregorian C, Drenan RM, Xiang Y, Regan JW, Insel PA (2001) Receptor number and caveolar co-localization determine receptor coupling efficiency to adenylyl cyclase. J Biol Chem 276 (45):42063-42069.

Ostrom RS, Gregorian C, Insel PA (2000a) Cellular release of and response to ATP as key determinants of the set-point of signal transduction pathways. J Biol Chem 275 (16):11735-11739

Ostrom RS, Insel PA (2004) The evolving role of lipid rafts and caveolae in G proteincoupled receptor signaling: Implications for molecular pharmacology. Br J Pharmacol 143 (2):235-245 
Ostrom RS, Liu X, Head BP, Gregorian C, Seasholtz TM, Insel PA (2002) Localization of adenylyl cyclase isoforms and $G$ protein-coupled receptors in vascular smooth muscle cells: expression in caveolin-rich and noncaveolin domains. Mol Pharmacol 62 (5):983-992

Ostrom RS, Post SR, Insel PA (2000b) Stoichiometry and Compartmentation in G Protein-coupled Receptor Signaling: Implications for Therapeutic Interventions Involving Gs. J Pharmacol Exp Ther 294 (2):407-412

Ostrom RS, Violin JD, Coleman S, Insel PA (2000c) Selective enhancement of betaadrenergic receptor signaling by overexpression of adenylyl cyclase type 6: colocalization of receptor and adenylyl cyclase in caveolae of cardiac myocytes. Mol Pharmacol 57 (5):1075-1079

Pang L, Knox AJ (1997) Effect of interleukin-1 beta, tumour necrosis factor-alpha and interferon-gamma on the induction of cyclo-oxygenase-2 in cultured human airway smooth muscle cells. Br J Pharmacol 121 (3):579-587. doi:10.1038/sj.bjp.0701152

Patel TB, Du Z, Pierre S, Cartin L, Scholich K (2001) Molecular biological approaches to unravel adenylyl cyclase signaling and function. Gene 269 (1-2):13-25

Pelaia G, Cuda G, Vatrella A, Gallelli L, Caraglia M, Marra M, Abbruzzese A, Caputi M, Maselli R, Costanzo FS, Marsico SA (2005) Mitogen-activated protein kinases and asthma. J Cell Physiol 202 (3):642-653. doi:10.1002/jcp.20169

Pfitzer G (2001) Invited review: regulation of myosin phosphorylation in smooth muscle. J Appl Physiol 91 (1):497-503

Pierce KL, Premont RT, Lefkowitz RJ (2002) Seven-transmembrane receptors. Nat Rev Mol Cell Biol 3 (9):639-650. doi:10.1038/nrm908

Pierre S, Eschenhagen T, Geisslinger G, Scholich K (2009) Capturing adenylyl cyclases as potential drug targets. Nature reviews Drug discovery 8 (4):321-335. doi: $10.1038 / \mathrm{nrd} 2827$

Piggott LA, Bauman AL, Scott JD, Dessauer CW (2008) The A-kinase anchoring protein Yotiao binds and regulates adenylyl cyclase in brain. Proc Natl Acad Sci U S A 105 (37):13835-13840. doi:10.1073/pnas.0712100105

Pike LJ (2003) Lipid rafts: bringing order to chaos. J Lipid Res 44 (4):655-667

Plaisance S, Vanden Berghe W, Boone E, Fiers W, Haegeman G (1997) Recombination signal sequence binding protein Jkappa is constitutively bound to the NF-kappaB site of the interleukin-6 promoter and acts as a negative regulatory factor. Mol Cell Biol 17 (7):3733-3743 
Prakash YS, Kannan MS, Sieck GC (1997) Regulation of intracellular calcium oscillations in porcine tracheal smooth muscle cells. Am J Physiol 272 (3 Pt 1):C966-975

Premont RT, Matsuoka I, Mattei MG, Pouille Y, Defer N, Hanoune J (1996) Identification and characterization of a widely expressed form of adenylyl cyclase. J Biol Chem 271 (23):13900-13907

Raychaudhuri N, Douglas RS, Smith TJ (2010) PGE2 induces IL-6 in orbital fibroblasts through EP2 receptors and increased gene promoter activity: implications to thyroid-associated ophthalmopathy. PLoS One 5 (12):e15296. doi:10.1371/journal.pone.0015296

Resh MD (2006) Palmitoylation of ligands, receptors, and intracellular signaling molecules. Sci STKE 2006 (359):re14

Rich TC, Fagan KA, Nakata H, Schaack J, Cooper DM, Karpen JW (2000) Cyclic nucleotide-gated channels colocalize with adenylyl cyclase in regions of restricted cAMP diffusion. The Journal of general physiology 116 (2):147-161

Rincon M, Irvin CG (2012) Role of IL-6 in asthma and other inflammatory pulmonary diseases. International journal of biological sciences 8 (9):1281-1290. doi:10.7150/ijbs.4874

Rose-John S, Scheller J, Elson G, Jones SA (2006) Interleukin-6 biology is coordinated by membrane-bound and soluble receptors: role in inflammation and cancer. Journal of leukocyte biology 80 (2):227-236. doi:10.1189/jlb.1105674

Roth DM, Bayat H, Drumm JD, Gao MH, Swaney JS, Ander A, Hammond HK (2002) Adenylyl cyclase increases survival in cardiomyopathy. Circulation 105 (16):1989-1994

Roth M, Johnson PR, Borger P, Bihl MP, Rudiger JJ, King GG, Ge Q, Hostettler K, Burgess JK, Black JL, Tamm M (2004) Dysfunctional interaction of C/EBPalpha and the glucocorticoid receptor in asthmatic bronchial smooth-muscle cells. N Engl J Med 351 (6):560-574. doi:10.1056/NEJMoa021660

Rubini A (2010) IL-6 increases airway resistance in the rat. Cytokine 51 (3):266-273. doi:10.1016/j.cyto.2010.06.015

Rybin VO, Xu X, Lisanti MP, Steinberg SF (2000) Differential targeting of beta adrenergic receptor subtypes and adenylyl cyclase to cardiomyocyte caveolae. A mechanism to functionally regulate the cAMP signaling pathway. J Biol Chem 275 (52):41447-41457. 
Salon JA, Lodowski DT, Palczewski K (2011) The significance of G protein-coupled receptor crystallography for drug discovery. Pharmacol Rev 63 (4):901-937. doi:10.1124/pr.110.003350

Scott JD, Dessauer CW, Tasken K (2013) Creating order from chaos: cellular regulation by kinase anchoring. Annu Rev Pharmacol Toxicol 53:187-210.

doi:10.1146/annurev-pharmtox-011112-140204

Sharman JL, Benson HE, Pawson AJ, Lukito V, Mpamhanga CP, Bombail V, Davenport AP, Peters JA, Spedding M, Harmar AJ, Nc I (2013) IUPHAR-DB: updated database content and new features. Nucleic Acids Res 41 (Database issue):D1083-1088. doi:10.1093/nar/gks960

Shaywitz AJ, Greenberg ME (1999) CREB: a stimulus-induced transcription factor activated by a diverse array of extracellular signals. Annu Rev Biochem 68:821861. doi:10.1146/annurev.biochem.68.1.821

Shen JX, Cooper DM (2013) AKAP79 and PKC, PKA and PDE4, participate in a Gqlinked muscarinic receptor and adenylyl cyclase 2 cAMP signalling complex. Biochem J. doi:10.1042/BJ20130359

Shore SA (2004) Airway smooth muscle in asthma--not just more of the same. N Engl J Med 351 (6):531-532. doi:10.1056/NEJMp048139

Simmerman HK, Collins JH, Theibert JL, Wegener AD, Jones LR (1986) Sequence analysis of phospholamban. Identification of phosphorylation sites and two major structural domains. J Biol Chem 261 (28):13333-13341

Small KM, McGraw DW, Liggett SB (2003) Pharmacology and physiology of human adrenergic receptor polymorphisms. Annu Rev Pharmacol Toxicol 43:381-411. doi:10.1146/annurev.pharmtox.43.100901.135823

Smith FD, Langeberg LK, Scott JD (2006) The where's and when's of kinase anchoring. Trends Biochem Sci 31 (6):316-323. doi:10.1016/j.tibs.2006.04.009

Smith WL, DeWitt DL, Garavito RM (2000) Cyclooxygenases: structural, cellular, and molecular biology. Annu Rev Biochem 69:145-182. doi:10.1146/annurev.biochem.69.1.145

Strandberg K, Palmberg L, Larsson K (2007) Effect of formoterol and salmeterol on IL-6 and IL-8 release in airway epithelial cells. Respiratory Medicine 101 (6):11321139. doi:10.1016/j.rmed.2006.11.014

Sutkowski EM, Tang WJ, Broome CW, Robbins JD, Seamon KB (1994) Regulation of forskolin interactions with type I, II, V and VI adenylyl cyclases by Gs alpha. Biochemistry 33:12852-12859 
Tanabe O, Akira S, Kamiya T, Wong GG, Hirano T, Kishimoto T (1988) Genomic structure of the murine IL-6 gene. High degree conservation of potential regulatory sequences between mouse and human. J Immunol 141 (11):3875-3881

Tang T, Gao MH, Hammond HK (2012) Prospects for gene transfer for clinical heart failure. Gene Ther 19 (6):606-612. doi:10.1038/gt.2012.36

Tang WJ, Gilman AG (1991) Type-specific regulation of adenylyl cyclase by G protein beta gamma subunits. Science 254 (5037):1500-1503

Tang WJ, Krupinski J, Gilman AG (1991) Expression and characterization of calmodulin-activated (type I) adenylylcyclase. The Journal of biological chemistry 266 (13):8595-8603

Taussig R, Iniguez-Lluhi JA, Gilman AG (1993a) Inhibition of adenylyl cyclase by Gi alpha. Science 261 (5118):218-221

Taussig R, Quarmby LM, Gilman AG (1993b) Regulation of purified type I and type II adenylylcyclases by $\mathrm{G}$ protein beta gamma subunits. The Journal of biological chemistry 268 (1):9-12

Taussig R, Tang WJ, Hepler JR, Gilman AG (1994) Distinct patterns of bidirectional regulation of mammalian adenylyl cyclases. The Journal of biological chemistry 269 (8):6093-6100

Tchivileva IE, Tan KS, Gambarian M, Nackley AG, Medvedev AV, Romanov S, Flood PM, Maixner W, Makarov SS, Diatchenko L (2009) Signaling pathways mediating beta3-adrenergic receptor-induced production of interleukin-6 in adipocytes. Mol Immunol 46 (11-12):2256-2266. doi:10.1016/j.molimm.2009.04.008

Timofeyev V, Myers RE, Kim HJ, Woltz RL, Sirish P, Heiserman JP, Li N, Singapuri A, Tang T, Yarov-Yarovoy V, Yamoah EN, Hammond HK, Chiamvimonvat N (2013) Adenylyl cyclase subtype-specific compartmentalization: differential regulation of L-type Ca2+ current in ventricular myocytes. Circ Res 112 (12):1567-1576. doi:10.1161/CIRCRESAHA.112.300370

Tliba O, Panettieri RA, Jr. (2009) Noncontractile functions of airway smooth muscle cells in asthma. Annu Rev Physiol 71:509-535.

doi:10.1146/annurev.physiol.010908.163227

Trian T, Burgess JK, Niimi K, Moir LM, Ge Q, Berger P, Liggett SB, Black JL, Oliver BG (2011) beta2-Agonist induced cAMP is decreased in asthmatic airway smooth muscle due to increased PDE4D. PLoS One 6 (5):e20000.

doi:10.1371/journal.pone.0020000 
Turki J, Pak J, Green SA, Martin RJ, Liggett SB (1995) Genetic polymorphisms of the beta 2-adrenergic receptor in nocturnal and nonnocturnal asthma. Evidence that Gly16 correlates with the nocturnal phenotype. J Clin Invest 95 (4):1635-1641. doi:10.1172/JCI117838

Vanden Berghe W, Plaisance S, Boone E, De Bosscher K, Schmitz ML, Fiers W, Haegeman G (1998) p38 and extracellular signal-regulated kinase mitogenactivated protein kinase pathways are required for nuclear factor-kappaB p65 transactivation mediated by tumor necrosis factor. J Biol Chem 273 (6):32853290

Vane JR, Bakhle YS, Botting RM (1998) Cyclooxygenases 1 and 2. Annu Rev Pharmacol Toxicol 38:97-120. doi:10.1146/annurev.pharmtox.38.1.97

Vatner SF, Yan L, Ishikawa Y, Vatner DE, Sadoshima J (2009) Adenylyl cyclase type 5 disruption prolongs longevity and protects the heart against stress. Circ J 73 (2):195-200

Walsh DA, Perkins JP, Krebs EG (1968) An adenosine 3',5'-monophosphate-dependant protein kinase from rabbit skeletal muscle. J Biol Chem 243 (13):3763-3765

Wang P, Zhu F, Konstantopoulos K (2010) Prostaglandin E2 induces interleukin-6 expression in human chondrocytes via cAMP/protein kinase A- and phosphatidylinositol 3-kinase-dependent NF-kappaB activation. American journal of physiology Cell physiology 298 (6):C1445-1456.

doi:10.1152/ajpcell.00508.2009

Watson PA, Krupinski J, Kempinski AM, Frankenfield CD (1994) Molecular cloning and characterization of the type VII isoform of mammalian adenylyl cyclase expressed widely in mouse tissues and in S49 mouse lymphoma cells. The Journal of biological chemistry 269 (46):28893-28898

Wayman GA, Wei J, Wong S, Storm DR (1996) Regulation of type I adenylyl cyclase by calmodulin kinase IV in vivo. Mol Cell Biol 16 (11):6075-6082

Wei J, Wayman G, Storm DR (1996) Phosphorylation and inhibition of type III adenylyl cyclase by calmodulin-dependent protein kinase II in vivo. J Biol Chem 271 (39):24231-24235

Wen AY, Sakamoto KM, Miller LS (2010) The role of the transcription factor CREB in immune function. J Immunol 185 (11):6413-6419. doi:10.4049/jimmunol.1001829

Willoughby D, Wong W, Schaack J, Scott JD, Cooper DM (2006) An anchored PKA and PDE4 complex regulates subplasmalemmal cAMP dynamics. Embo J 25 (10):2051-2061. doi:10.1038/sj.emboj.7601113 
Wooldridge AA, MacDonald JA, Erdodi F, Ma C, Borman MA, Hartshorne DJ, Haystead TA (2004) Smooth muscle phosphatase is regulated in vivo by exclusion of phosphorylation of threonine 696 of MYPT1 by phosphorylation of Serine 695 in response to cyclic nucleotides. J Biol Chem 279 (33):34496-34504.

doi:10.1074/jbc.M405957200

Yeganeh B, Xia C, Movassagh H, Koziol-White C, Chang Y, Al-Alwan L, Bourke JE, Oliver BG (2013) Emerging mediators of airway smooth muscle dysfunction in asthma. Pulm Pharmacol Ther 26 (1):105-111. doi:10.1016/j.pupt.2012.06.011

Yoshimura M, Cooper DM (1992) Cloning and expression of a Ca(2+)-inhibitable adenylyl cyclase from NCB-20 cells. Proc Natl Acad Sci U S A 89 (15):67166720

Zhong H, Belardinelli L, Maa T, Zeng D (2005) Synergy between A2B adenosine receptors and hypoxia in activating human lung fibroblasts. Am J Respir Cell Mol Biol 32 (1):2-8. doi:10.1165/rcmb.2004-0103OC 
APPENDIX. PCR ARRAYS

Table A-1. Fsk-induced gene regulation in AC overexpressing BSMC compared to control BSMC

\begin{tabular}{|c|c|c|c|c|c|c|c|}
\hline \multirow[b]{2}{*}{ Gene } & \multirow[b]{2}{*}{ Description } & \multicolumn{2}{|c|}{$\mathrm{AC2}$} & \multicolumn{2}{|c|}{ AC3 } & \multicolumn{2}{|c|}{ AC6 } \\
\hline & & $\begin{array}{c}\text { Fold } \\
\text { Change }\end{array}$ & SEM & $\begin{array}{c}\text { Fold } \\
\text { Change }\end{array}$ & SEM & $\begin{array}{c}\text { Fold } \\
\text { Change }\end{array}$ & SEM \\
\hline ADRB1 & $\begin{array}{l}\text { Adrenergic, beta-1-, } \\
\text { receptor }\end{array}$ & -0.445 & 0.956 & -0.302 & 0.872 & 1.496 & 0.152 \\
\hline AHR & Aryl hydrocarbon receptor & 1.458 & 1.595 & -1.276 & 1.189 & -1.957 & 1.673 \\
\hline AMD1 & $\begin{array}{l}\text { Adenosylmethionine } \\
\text { decarboxylase } 1\end{array}$ & 1.040 & 1.421 & -2.709 & 2.176 & -2.241 & 2.075 \\
\hline AREG & Amphiregulin & 3.743 & 2.157 & 1.099 & 2.588 & 10.334 & 4.347 \\
\hline ATF3 & $\begin{array}{l}\text { Activating transcription } \\
\text { factor } 3\end{array}$ & 2.749 & 1.071 & -1.074 & 1.261 & -2.488 & 0.733 \\
\hline BCL2 & B-cell CLL/lymphoma 2 & 0.534 & 1.124 & -1.454 & 0.368 & 0.698 & 1.064 \\
\hline BDNF & $\begin{array}{l}\text { Brain-derived neurotrophic } \\
\text { factor }\end{array}$ & 0.864 & 1.048 & -1.130 & 1.347 & -0.367 & 1.123 \\
\hline BRCA1 & Breast cancer 1 , early onset & 0.849 & 1.316 & -0.459 & 0.808 & -2.474 & 0.124 \\
\hline CALB1 & Calbindin $1,28 \mathrm{kDa}$ & -0.445 & 0.956 & -0.315 & 0.880 & 1.366 & 0.213 \\
\hline CALB2 & Calbindin 2 & -0.876 & 1.215 & 0.393 & 0.708 & 0.559 & 0.925 \\
\hline CALM1 & $\begin{array}{l}\text { Calmodulin } 1 \\
\text { (phosphorylase kinase, } \\
\text { delta) }\end{array}$ & 1.772 & 0.194 & -0.774 & 1.043 & -1.859 & 1.759 \\
\hline CALR & Calreticulin & 0.634 & 1.049 & -0.240 & 1.354 & -6.404 & 6.629 \\
\hline CCNA1 & Cyclin A1 & 1.806 & 1.753 & 0.855 & 1.446 & -1.200 & 1.267 \\
\hline
\end{tabular}


Table A-1. (Continued)

\begin{tabular}{|c|c|c|c|c|c|c|c|}
\hline \multirow[b]{2}{*}{ Gene } & \multirow[b]{2}{*}{ Description } & \multicolumn{2}{|c|}{ AC2 } & \multicolumn{2}{|c|}{$\mathrm{AC3}$} & \multicolumn{2}{|c|}{ AC6 } \\
\hline & & $\begin{array}{c}\text { Fold } \\
\text { Change }\end{array}$ & SEM & $\begin{array}{c}\text { Fold } \\
\text { Change }\end{array}$ & SEM & $\begin{array}{c}\text { Fold } \\
\text { Change }\end{array}$ & SEM \\
\hline CCND1 & Cyclin D1 & 0.608 & 1.234 & -1.668 & 1.467 & -3.416 & 1.452 \\
\hline CDK5 & Cyclin-dependent kinase 5 & 0.580 & 1.385 & -1.828 & 1.691 & -1.970 & 0.534 \\
\hline CDKN2B & $\begin{array}{l}\text { Cyclin-dependent kinase } \\
\text { inhibitor } 2 \mathrm{~B}(\mathrm{p} 15, \text { inhibits } \\
\text { CDK4) }\end{array}$ & 2.161 & 0.534 & -1.101 & 1.354 & -2.088 & 0.364 \\
\hline CGA & $\begin{array}{l}\text { Glycoprotein hormones, } \\
\text { alpha polypeptide }\end{array}$ & 0.412 & 0.886 & 0.415 & 0.776 & 0.472 & 0.964 \\
\hline CHGA & $\begin{array}{l}\text { Chromogranin A } \\
\text { (parathyroid secretory } \\
\text { protein 1) }\end{array}$ & -0.450 & 0.958 & -0.315 & 0.880 & 1.480 & 0.155 \\
\hline CNN1 & $\begin{array}{l}\text { Calponin } 1 \text {, basic, smooth } \\
\text { muscle }\end{array}$ & -1.138 & 1.204 & -1.691 & 0.144 & -1.391 & 0.173 \\
\hline CREB1 & $\begin{array}{l}\text { CAMP responsive element } \\
\text { binding protein } 1\end{array}$ & 0.449 & 1.351 & -0.946 & 1.042 & -0.813 & 0.927 \\
\hline CREM & $\begin{array}{l}\text { CAMP responsive element } \\
\text { modulator }\end{array}$ & 0.864 & 1.433 & -0.939 & 1.242 & 1.562 & 0.104 \\
\hline CTF1 & Cardiotrophin 1 & 0.297 & 0.860 & -0.664 & 0.973 & -2.368 & 0.784 \\
\hline CYR61 & $\begin{array}{l}\text { Cysteine-rich, angiogenic } \\
\text { inducer, } 61\end{array}$ & 1.121 & 1.233 & 0.378 & 0.892 & -2.096 & 0.346 \\
\hline DDIT3 & $\begin{array}{l}\text { DNA-damage-inducible } \\
\text { transcript } 3\end{array}$ & 1.856 & 0.485 & 0.468 & 0.875 & 0.785 & 1.794 \\
\hline DUSP1 & $\begin{array}{l}\text { Dual specificity } \\
\text { phosphatase } 1\end{array}$ & 3.385 & 2.744 & -1.144 & 1.823 & -0.839 & 1.644 \\
\hline EGR1 & Early growth response 1 & 3.694 & 2.382 & -0.188 & 1.958 & -2.223 & 1.977 \\
\hline
\end{tabular}


Table A-1. (Continued)

\begin{tabular}{|c|c|c|c|c|c|c|c|}
\hline \multirow[b]{2}{*}{ Gene } & \multirow[b]{2}{*}{ Description } & \multicolumn{2}{|c|}{ AC2 } & \multicolumn{2}{|c|}{ AC3 } & \multicolumn{2}{|c|}{ AC6 } \\
\hline & & $\begin{array}{c}\text { Fold } \\
\text { Change }\end{array}$ & SEM & $\begin{array}{c}\text { Fold } \\
\text { Change }\end{array}$ & SEM & $\begin{array}{c}\text { Fold } \\
\text { Change }\end{array}$ & SEM \\
\hline EGR2 & Early growth response 2 & 1.223 & 1.232 & -0.315 & 0.880 & 1.527 & 0.151 \\
\hline ENO2 & $\begin{array}{l}\text { Enolase } 2 \text { (gamma, } \\
\text { neuronal) }\end{array}$ & 0.791 & 1.138 & -2.244 & 1.953 & -1.607 & 0.201 \\
\hline FGF6 & Fibroblast growth factor 6 & -0.445 & 0.956 & -0.315 & 0.880 & 1.366 & 0.213 \\
\hline FOS & $\begin{array}{l}\text { FBJ murine osteosarcoma } \\
\text { viral oncogene homolog }\end{array}$ & 3.736 & 1.400 & -0.666 & 2.957 & 3.687 & 2.110 \\
\hline FOSB & $\begin{array}{l}\text { FBJ murine osteosarcoma } \\
\text { viral oncogene homolog } B\end{array}$ & 0.430 & 1.613 & -0.602 & 0.854 & -0.433 & 0.847 \\
\hline GCG & Glucagon & -0.445 & 0.956 & -0.315 & 0.880 & 1.366 & 0.213 \\
\hline GEM & $\begin{array}{l}\text { GTP binding protein } \\
\text { overexpressed in skeletal } \\
\text { muscle }\end{array}$ & 0.406 & 1.102 & -1.401 & 1.323 & -0.361 & 0.994 \\
\hline GIPR & $\begin{array}{l}\text { Gastric inhibitory } \\
\text { polypeptide receptor }\end{array}$ & -2.301 & 0.570 & -0.739 & 0.936 & -0.791 & 0.956 \\
\hline HK2 & Hexokinase 2 & 0.168 & 0.985 & -1.086 & 1.211 & -0.717 & 0.883 \\
\hline HSPA4 & $\begin{array}{l}\text { Heat shock } 70 \mathrm{kDa} \text { protein } \\
4\end{array}$ & -0.491 & 0.811 & -1.689 & 0.571 & -2.123 & 0.620 \\
\hline HSPA5 & $\begin{array}{l}\text { Heat shock } 70 \mathrm{kDa} \text { protein } \\
5 \text { (glucose-regulated } \\
\text { protein, } 78 \mathrm{kDa})\end{array}$ & 2.143 & 2.234 & -1.599 & 1.515 & -1.335 & 1.195 \\
\hline IL2 & Interleukin 2 & -0.445 & 0.956 & -0.315 & 0.880 & 1.366 & 0.213 \\
\hline IL6 & $\begin{array}{l}\text { Interleukin } 6 \text { (interferon, } \\
\text { beta 2) }\end{array}$ & 77.159 & 50.029 & 0.115 & 1.667 & -0.469 & 0.747 \\
\hline INHBA & Inhibin, beta $\mathrm{A}$ & 2.066 & 1.850 & -1.135 & 1.072 & 0.462 & 0.758 \\
\hline
\end{tabular}


Table A-1. (Continued)

\begin{tabular}{|c|c|c|c|c|c|c|c|}
\hline \multirow[b]{2}{*}{ Gene } & \multirow[b]{2}{*}{ Description } & \multicolumn{2}{|c|}{ AC2 } & \multicolumn{2}{|c|}{$\mathrm{AC3}$} & \multicolumn{2}{|c|}{ AC6 } \\
\hline & & $\begin{array}{c}\text { Fold } \\
\text { Change }\end{array}$ & SEM & $\begin{array}{c}\text { Fold } \\
\text { Change }\end{array}$ & SEM & $\begin{array}{c}\text { Fold } \\
\text { Change }\end{array}$ & SEM \\
\hline JUNB & Jun B proto-oncogene & 0.721 & 1.078 & -1.579 & 1.499 & -1.956 & 0.516 \\
\hline JUND & Jun D proto-oncogene & 0.171 & 1.050 & -2.122 & 0.706 & -0.787 & 1.003 \\
\hline KCNA5 & $\begin{array}{l}\text { Potassium voltage-gated } \\
\text { channel, shaker-related } \\
\text { subfamily, member } 5\end{array}$ & -0.445 & 0.956 & -0.315 & 0.880 & 1.366 & 0.213 \\
\hline LDHA & Lactate dehydrogenase A & -0.486 & 1.901 & -1.323 & 1.239 & 0.300 & 0.815 \\
\hline MAF & $\begin{array}{l}\text { V-maf musculoaponeurotic } \\
\text { fibrosarcoma oncogene } \\
\text { homolog (avian) }\end{array}$ & -2.022 & 0.453 & -1.092 & 1.114 & -0.290 & 0.865 \\
\hline MIF & $\begin{array}{l}\text { Macrophage migration } \\
\text { inhibitory factor } \\
\text { (glycosylation-inhibiting } \\
\text { factor) }\end{array}$ & 0.268 & 1.040 & -0.595 & 0.912 & 1.283 & 0.139 \\
\hline NCAM1 & $\begin{array}{l}\text { Neural cell adhesion } \\
\text { molecule } 1\end{array}$ & -0.445 & 0.956 & -0.315 & 0.880 & 1.366 & 0.213 \\
\hline NF1 & Neurofibromin 1 & -1.347 & 0.156 & 0.187 & 0.991 & -1.265 & 0.163 \\
\hline NOS2 & $\begin{array}{l}\text { Nitric oxide synthase } 2 \text {, } \\
\text { inducible }\end{array}$ & -0.445 & 0.956 & -0.315 & 0.880 & 1.366 & 0.213 \\
\hline NPY & Neuropeptide Y & 0.499 & 0.875 & -0.501 & 0.798 & 1.364 & 0.078 \\
\hline NR4A2 & $\begin{array}{l}\text { Nuclear receptor subfamily } \\
4, \text { group A, member } 2\end{array}$ & 6.710 & 4.372 & -0.419 & 1.573 & 2.391 & 0.833 \\
\hline PCK2 & $\begin{array}{l}\text { Phosphoenolpyruvate } \\
\text { carboxykinase } 2 \\
\text { (mitochondrial) }\end{array}$ & -0.857 & 1.051 & -2.836 & 0.818 & -0.605 & 1.203 \\
\hline
\end{tabular}


Table A-1. (Continued)

\begin{tabular}{|c|c|c|c|c|c|c|c|}
\hline \multirow[b]{2}{*}{ Gene } & \multirow[b]{2}{*}{ Description } & \multicolumn{2}{|c|}{ AC2 } & \multicolumn{2}{|c|}{$\mathrm{AC3}$} & \multicolumn{2}{|c|}{ AC6 } \\
\hline & & $\begin{array}{c}\text { Fold } \\
\text { Change }\end{array}$ & SEM & $\begin{array}{c}\text { Fold } \\
\text { Change }\end{array}$ & SEM & $\begin{array}{c}\text { Fold } \\
\text { Change }\end{array}$ & SEM \\
\hline PCNA & $\begin{array}{l}\text { Proliferating cell nuclear } \\
\text { antigen }\end{array}$ & 0.728 & 1.291 & -1.772 & 0.314 & -2.075 & 0.511 \\
\hline PENK & Proenkephalin & 0.621 & 1.048 & -1.324 & 0.099 & -1.358 & 0.156 \\
\hline PER1 & $\begin{array}{l}\text { Period homolog } 1 \\
\text { (Drosophila) }\end{array}$ & -1.256 & 0.156 & -2.071 & 0.385 & -0.439 & 0.738 \\
\hline PLAT & $\begin{array}{l}\text { Plasminogen activator, } \\
\text { tissue }\end{array}$ & 0.541 & 1.753 & -1.854 & 0.592 & -1.013 & 1.131 \\
\hline PLN & Phospholamban & -1.680 & 0.379 & -1.536 & 0.169 & 0.864 & 1.161 \\
\hline PMAIP1 & $\begin{array}{l}\text { Phorbol-12-myristate-13- } \\
\text { acetate-induced protein } 1\end{array}$ & 0.617 & 1.374 & -1.889 & 0.682 & 1.621 & 0.026 \\
\hline POU1F1 & POU class 1 homeobox 1 & -0.445 & 0.956 & 0.384 & 0.873 & 1.643 & 0.317 \\
\hline POU2AF1 & $\begin{array}{l}\text { POU class } 2 \text { associating } \\
\text { factor } 1\end{array}$ & -0.398 & 0.939 & -0.377 & 0.770 & 1.252 & 0.107 \\
\hline PPP1R15A & $\begin{array}{l}\text { Protein phosphatase } 1 \text {, } \\
\text { regulatory (inhibitor) } \\
\text { subunit } 15 \mathrm{~A}\end{array}$ & 1.046 & 1.763 & -1.422 & 1.380 & -2.866 & 2.936 \\
\hline PPP2CA & $\begin{array}{l}\text { Protein phosphatase } 2, \\
\text { catalytic subunit, alpha } \\
\text { isozyme }\end{array}$ & 0.643 & 0.896 & -2.441 & 0.794 & -1.167 & 1.202 \\
\hline PRKAR1A & $\begin{array}{l}\text { Protein kinase, cAMP- } \\
\text { dependent, regulatory, type } \\
\text { I, alpha (tissue specific } \\
\text { extinguisher 1) }\end{array}$ & -0.265 & 1.289 & -2.188 & 0.867 & -1.532 & 0.220 \\
\hline PRL & Prolactin & -0.445 & 0.956 & -0.315 & 0.880 & 1.757 & 0.394 \\
\hline
\end{tabular}


Table A-1. (Continued)

\begin{tabular}{|c|c|c|c|c|c|c|c|}
\hline \multirow[b]{2}{*}{ Gene } & \multirow[b]{2}{*}{ Description } & \multicolumn{2}{|c|}{ AC2 } & \multicolumn{2}{|c|}{$\mathrm{AC3}$} & \multicolumn{2}{|c|}{ AC6 } \\
\hline & & $\begin{array}{c}\text { Fold } \\
\text { Change }\end{array}$ & SEM & $\begin{array}{c}\text { Fold } \\
\text { Change }\end{array}$ & SEM & $\begin{array}{c}\text { Fold } \\
\text { Change }\end{array}$ & SEM \\
\hline PTGS2 & $\begin{array}{l}\text { Prostaglandin- } \\
\text { endoperoxide synthase } 2 \\
\text { (prostaglandin } \mathrm{G} / \mathrm{H} \\
\text { synthase and } \\
\text { cyclooxygenase) }\end{array}$ & 11.294 & 7.522 & -0.737 & 1.199 & 2.560 & 1.004 \\
\hline RB1 & Retinoblastoma 1 & 1.273 & 0.096 & -0.440 & 0.973 & -0.738 & 0.965 \\
\hline S100A12 & $\begin{array}{l}\text { S100 calcium binding } \\
\text { protein } \mathrm{A} 12\end{array}$ & -0.445 & 0.956 & -0.315 & 0.880 & 1.366 & 0.213 \\
\hline S100A6 & $\begin{array}{l}\text { S100 calcium binding } \\
\text { protein A6 }\end{array}$ & -1.747 & 0.510 & -1.924 & 0.186 & -1.225 & 0.100 \\
\hline S100G & $\begin{array}{l}\text { S100 calcium binding } \\
\text { protein } G\end{array}$ & 2.214 & 0.627 & -0.157 & 0.932 & 2.320 & 0.790 \\
\hline SCG2 & Secretogranin II & -4.204 & 3.440 & -0.944 & 1.056 & 2.598 & 0.189 \\
\hline SGK1 & $\begin{array}{l}\text { Serum/glucocorticoid } \\
\text { regulated kinase } 1\end{array}$ & 0.397 & 0.894 & -0.743 & 0.956 & 1.807 & 1.732 \\
\hline SLC18A1 & $\begin{array}{l}\text { Solute carrier family } 18 \\
\text { (vesicular monoamine), } \\
\text { member } 1\end{array}$ & -0.445 & 0.956 & -0.315 & 0.880 & 1.366 & 0.213 \\
\hline SOD2 & $\begin{array}{l}\text { Superoxide dismutase } 2 \text {, } \\
\text { mitochondrial }\end{array}$ & -1356.5 & 1369.7 & -0.267 & 0.969 & -2.159 & 2.664 \\
\hline SRF & $\begin{array}{l}\text { Serum response factor (c- } \\
\text { fos serum response } \\
\text { element-binding } \\
\text { transcription factor) }\end{array}$ & 0.458 & 0.864 & -0.997 & 1.083 & -0.522 & 1.215 \\
\hline
\end{tabular}


Table A-1. (Continued)

\begin{tabular}{|c|c|c|c|c|c|c|c|}
\hline \multirow[b]{2}{*}{ Gene } & \multirow[b]{2}{*}{ Description } & \multicolumn{2}{|c|}{$\mathrm{AC2}$} & \multicolumn{2}{|c|}{ AC3 } & \multicolumn{2}{|c|}{ AC6 } \\
\hline & & $\begin{array}{c}\text { Fold } \\
\text { Change }\end{array}$ & SEM & $\begin{array}{c}\text { Fold } \\
\text { Change }\end{array}$ & SEM & $\begin{array}{c}\text { Fold } \\
\text { Change }\end{array}$ & SEM \\
\hline SST & Somatostatin & -0.826 & 1.466 & 1.072 & 1.283 & 9.737 & 0.791 \\
\hline SSTR2 & Somatostatin receptor 2 & 0.363 & 0.989 & -1.342 & 0.025 & 2.003 & 0.487 \\
\hline STAT3 & $\begin{array}{l}\text { Signal transducer and } \\
\text { activator of transcription } 3 \\
\text { (acute-phase response } \\
\text { factor) }\end{array}$ & 0.434 & 0.900 & -1.369 & 0.011 & -0.535 & 0.982 \\
\hline TACR1 & Tachykinin receptor 1 & 0.441 & 1.027 & -1.600 & 0.304 & 0.820 & 1.353 \\
\hline TGFB3 & $\begin{array}{l}\text { Transforming growth } \\
\text { factor, beta } 3\end{array}$ & -0.301 & 0.831 & -1.523 & 0.295 & 0.981 & 1.059 \\
\hline TH & Tyrosine hydroxylase & -0.445 & 0.956 & -0.315 & 0.880 & 1.366 & 0.213 \\
\hline THBS1 & Thrombospondin 1 & -1.681 & 0.140 & -1.649 & 0.055 & -0.792 & 0.956 \\
\hline TNF & Tumor necrosis factor & -0.445 & 0.956 & -0.315 & 0.880 & 1.366 & 0.213 \\
\hline VCL & Vinculin & -0.340 & 1.321 & -0.570 & 1.212 & 0.836 & 1.330 \\
\hline VIP & $\begin{array}{l}\text { Vasoactive intestinal } \\
\text { peptide }\end{array}$ & 1.910 & 0.520 & -1.575 & 0.514 & 0.169 & 1.120 \\
\hline
\end{tabular}

Notes: BSMC were treated with $1 \mu \mathrm{M}$ Fsk for $24 \mathrm{~h}$. Gene expression is expressed as fold change with respect to lacZ. 
Table A-2. Fsk-induced gene regulation in AC overexpressing HEK compared to control HEK

\begin{tabular}{|c|c|c|c|}
\hline Gene & Description & AC2 & AC6 \\
\hline ADRB1 & Adrenergic, beta-1-, receptor & 1.879 & 1.3472 \\
\hline AHR & Aryl hydrocarbon receptor & 1.2142 & 1.4241 \\
\hline AMD1 & Adenosylmethionine decarboxylase 1 & 1.257 & -1.0425 \\
\hline AREG & Amphiregulin & 1.014 & 1.4948 \\
\hline ATF3 & Activating transcription factor 3 & 1.1892 & 1.366 \\
\hline BCL2 & B-cell CLL/lymphoma 2 & 1.0718 & 1.1173 \\
\hline BDNF & Brain-derived neurotrophic factor & 1.4743 & 1.0644 \\
\hline BRCA1 & Breast cancer 1 , early onset & 1.0792 & 1.2058 \\
\hline CALB1 & Calbindin $1,28 \mathrm{kDa}$ & 1.5583 & -1.057 \\
\hline CALB2 & Calbindin 2 & 1.5583 & -1.057 \\
\hline CALM1 & $\begin{array}{l}\text { Calmodulin } 1 \text { (phosphorylase kinase, } \\
\text { delta) }\end{array}$ & 1.5583 & 1.1251 \\
\hline CALR & Calreticulin & 1.9453 & 1.1173 \\
\hline CCNA1 & Cyclin A1 & 1.3947 & 1.6586 \\
\hline CCND1 & Cyclin D1 & -148.0561 & -1.4142 \\
\hline CDK5 & Cyclin-dependent kinase 5 & 1.2226 & 1.1019 \\
\hline CDKN2B & $\begin{array}{l}\text { Cyclin-dependent kinase inhibitor 2B } \\
\text { (p15, inhibits CDK4) }\end{array}$ & 1.4044 & 1.0497 \\
\hline CGA & $\begin{array}{l}\text { Glycoprotein hormones, alpha } \\
\text { polypeptide }\end{array}$ & 1.1728 & 1.7654 \\
\hline CHGA & $\begin{array}{l}\text { Chromogranin A (parathyroid } \\
\text { secretory protein 1) }\end{array}$ & 1.0497 & -1.0943 \\
\hline CNN1 & Calponin 1, basic, smooth muscle & -1.0718 & -3.0951 \\
\hline CREB1 & $\begin{array}{l}\text { CAMP responsive element binding } \\
\text { protein } 1\end{array}$ & 1.3195 & 1.2226 \\
\hline CREM & CAMP responsive element modulator & 1.2226 & 1.4845 \\
\hline CTF1 & Cardiotrophin 1 & 1.9453 & -1.4743 \\
\hline CYR61 & Cysteine-rich, angiogenic inducer, 61 & 2.1435 & -1.0644 \\
\hline DDIT3 & DNA-damage-inducible transcript 3 & 1.7654 & 1.879 \\
\hline DUSP1 & Dual specificity phosphatase 1 & 1.0497 & 1.0718 \\
\hline EGR1 & Early growth response 1 & 1.0644 & 1.0943 \\
\hline EGR2 & Early growth response 2 & 2.4794 & -1.1408 \\
\hline ENO2 & Enolase 2 (gamma, neuronal) & -1.0497 & -1.6358 \\
\hline FGF6 & Fibroblast growth factor 6 & 1.7171 & -1.057 \\
\hline FOS & $\begin{array}{l}\text { FBJ murine osteosarcoma viral } \\
\text { oncogene homolog }\end{array}$ & -1.014 & -1.0353 \\
\hline
\end{tabular}


Table A-2. (Continued)

\begin{tabular}{|c|c|c|c|}
\hline Gene & Description & $\mathrm{AC2}$ & AC6 \\
\hline FOSB & $\begin{array}{l}\text { FBJ murine osteosarcoma viral } \\
\text { oncogene homolog B }\end{array}$ & 1.1487 & 1.2924 \\
\hline GCG & Glucagon & 1.5583 & -1.057 \\
\hline GEM & $\begin{array}{l}\text { GTP binding protein overexpressed in } \\
\text { skeletal muscle }\end{array}$ & 1.8532 & 1.6472 \\
\hline GIPR & Gastric inhibitory polypeptide receptor & 3.9177 & 1.3287 \\
\hline HK2 & Hexokinase 2 & 2 & -1.0644 \\
\hline HSPA4 & Heat shock $70 \mathrm{kDa}$ protein 4 & 1.7777 & -1 \\
\hline HSPA5 & $\begin{array}{l}\text { Heat shock } 70 \mathrm{kDa} \text { protein } 5 \text { (glucose- } \\
\text { regulated protein, } 78 \mathrm{kDa})\end{array}$ & -1.0644 & 1.6133 \\
\hline IL2 & Interleukin 2 & 1.5583 & -1.057 \\
\hline IL6 & Interleukin 6 (interferon, beta 2) & 1.5583 & 1.6586 \\
\hline INHBA & Inhibin, beta $A$ & -1.0718 & 1.9053 \\
\hline JUNB & Jun B proto-oncogene & 1.021 & -1.6358 \\
\hline JUND & Jun D proto-oncogene & 1.3287 & -1.5052 \\
\hline KCNA5 & $\begin{array}{l}\text { Potassium voltage-gated channel, } \\
\text { shaker-related subfamily, member } 5\end{array}$ & 1.5583 & -1.057 \\
\hline LDHA & Lactate dehydrogenase A & 1.3104 & 1.7532 \\
\hline MAF & $\begin{array}{l}\text { V-maf musculoaponeurotic } \\
\text { fibrosarcoma oncogene homolog } \\
\text { (avian) }\end{array}$ & 1.5157 & 2.0994 \\
\hline MIF & $\begin{array}{l}\text { Macrophage migration inhibitory } \\
\text { factor (glycosylation-inhibiting factor) }\end{array}$ & 1.5583 & 1.8025 \\
\hline NCAM1 & Neural cell adhesion molecule 1 & 1.6818 & 2.2658 \\
\hline NF1 & Neurofibromin 1 & 1.5369 & 1.6472 \\
\hline NOS2 & Nitric oxide synthase 2 , inducible & 1.0425 & 1.3287 \\
\hline NPY & Neuropeptide Y & -1.181 & 1.2746 \\
\hline NR4A2 & $\begin{array}{l}\text { Nuclear receptor subfamily } 4 \text {, group } \\
\text { A, member } 2\end{array}$ & 1.1329 & 1.6358 \\
\hline PCK2 & $\begin{array}{l}\text { Phosphoenolpyruvate carboxykinase } 2 \\
\text { (mitochondrial) }\end{array}$ & 1.057 & -1.0792 \\
\hline PCNA & Proliferating cell nuclear antigen & 1.0867 & 1.014 \\
\hline PENK & Proenkephalin & 1.057 & -1.0497 \\
\hline PER1 & Period homolog 1 (Drosophila) & 1.4241 & -1.8404 \\
\hline PLAT & Plasminogen activator, tissue & 1.5052 & 1.0425 \\
\hline PLN & Phospholamban & 1.1019 & 1.815 \\
\hline PMAIP1 & $\begin{array}{l}\text { Phorbol-12-myristate-13-acetate- } \\
\text { induced protein } 1\end{array}$ & 1.4845 & 1.5476 \\
\hline POU1F1 & POU class 1 homeobox 1 & 1.5911 & 1.1019 \\
\hline POU2AF1 & POU class 2 associating factor 1 & 1.3472 & -1.3013 \\
\hline
\end{tabular}


Table A-2. (Continued)

\begin{tabular}{|c|c|c|c|}
\hline Gene & Description & $\mathrm{AC2}$ & AC6 \\
\hline PPP1R15A & $\begin{array}{l}\text { Protein phosphatase 1, regulatory } \\
\text { (inhibitor) subunit 15A }\end{array}$ & 1.0497 & -1.4948 \\
\hline PPP2CA & $\begin{array}{l}\text { Protein phosphatase } 2 \text {, catalytic } \\
\text { subunit, alpha isozyme }\end{array}$ & -1 & 1.2746 \\
\hline PRKAR1A & $\begin{array}{l}\text { Protein kinase, cAMP-dependent, } \\
\text { regulatory, type I, alpha (tissue } \\
\text { specific extinguisher 1) }\end{array}$ & 1.3195 & -1.0425 \\
\hline PRL & Prolactin & 1.5583 & -1.057 \\
\hline PTGS2 & $\begin{array}{l}\text { Prostaglandin-endoperoxide synthase } \\
2 \text { (prostaglandin G/H synthase and } \\
\text { cyclooxygenase) }\end{array}$ & 1.1251 & 1.3947 \\
\hline RB1 & Retinoblastoma 1 & 1.1975 & 1.2924 \\
\hline S100A12 & S100 calcium binding protein A12 & 1.5583 & -1.057 \\
\hline S100A6 & S100 calcium binding protein A6 & 1.5583 & 1.0943 \\
\hline S100G & S100 calcium binding protein $\mathrm{G}$ & 3.8637 & 2.7511 \\
\hline SCG2 & Secretogranin II & -1.2483 & 1.4044 \\
\hline SGK1 & $\begin{array}{l}\text { Serum/glucocorticoid regulated kinase } \\
1\end{array}$ & 1.0497 & 1.9053 \\
\hline SLC18A1 & $\begin{array}{l}\text { Solute carrier family } 18 \text { (vesicular } \\
\text { monoamine), member } 1\end{array}$ & 1.5583 & -1.057 \\
\hline SOD2 & $\begin{array}{l}\text { Superoxide dismutase } 2 \text {, } \\
\text { mitochondrial }\end{array}$ & 1.1251 & 1.1728 \\
\hline SRF & $\begin{array}{l}\text { Serum response factor (c-fos serum } \\
\text { response element-binding transcription } \\
\text { factor) }\end{array}$ & 1.2226 & -1.1567 \\
\hline SST & Somatostatin & 1.5583 & -1.057 \\
\hline SSTR2 & Somatostatin receptor 2 & 1.6586 & 1.434 \\
\hline STAT3 & $\begin{array}{l}\text { Signal transducer and activator of } \\
\text { transcription } 3 \text { (acute-phase response } \\
\text { factor) }\end{array}$ & 1.0353 & 1.257 \\
\hline TACR1 & Tachykinin receptor 1 & 2.042 & -1.1096 \\
\hline TGFB3 & Transforming growth factor, beta 3 & 1.0943 & -1.366 \\
\hline TH & Tyrosine hydroxylase & 1.5583 & -1.057 \\
\hline THBS1 & Thrombospondin 1 & 1.2226 & 1.5583 \\
\hline TNF & Tumor necrosis factor & 1.5692 & 4.8568 \\
\hline VCL & Vinculin & 1.1173 & 1.4641 \\
\hline VIP & Vasoactive intestinal peptide & 1.8921 & 4.4691 \\
\hline
\end{tabular}

Notes: HEK-293 were treated with $1 \mu \mathrm{M}$ Fsk for $24 \mathrm{~h}$. Gene expression is expressed as fold change with respect to empty pEGFP-n1 vector. 
Table A-3. GPCR expression in BSMC

\begin{tabular}{|c|c|c|c|}
\hline Gene & Description & $\begin{array}{l}\text { Average } \\
\text { CP }\end{array}$ & SD \\
\hline LPAR1 & Lysophosphatidic acid receptor 1 & 23.49 & 0.30 \\
\hline F2R & Coagulation factor II (thrombin) receptor & 23.58 & 0.37 \\
\hline GPR176 & G protein-coupled receptor 176 & 24.41 & 0.10 \\
\hline PDGFRB & $\begin{array}{l}\text { Platelet-derived growth factor receptor, beta } \\
\text { polypeptide }\end{array}$ & 24.76 & 0.24 \\
\hline F2RL2 & $\begin{array}{l}\text { Coagulation factor II (thrombin) receptor-like } \\
2\end{array}$ & 24.92 & 0.40 \\
\hline $\begin{array}{l}\text { SIGMAR } \\
1\end{array}$ & Sigma non-opioid intracellular receptor 1 & 25.06 & 0.21 \\
\hline FZD1 & Frizzled family receptor 1 & 25.40 & 0.30 \\
\hline CCRL1 & Chemokine (C-C motif) receptor-like 1 & 25.82 & 0.23 \\
\hline NPR2 & $\begin{array}{l}\text { Natriuretic peptide receptor B/guanylate } \\
\text { cyclase B (atrionatriuretic peptide receptor B) }\end{array}$ & 25.82 & 0.18 \\
\hline TM2D1 & TM2 domain containing 1 & 25.85 & 0.28 \\
\hline EDNRB & Endothelin receptor type B & 25.90 & 0.25 \\
\hline FZD6 & Frizzled family receptor 6 & 26.00 & 0.14 \\
\hline LPHN2 & Latrophilin 2 & 26.01 & 0.18 \\
\hline GPRC5A & $\begin{array}{l}\text { G protein-coupled receptor, family } \mathrm{C} \text {, group } 5 \text {, } \\
\text { member A }\end{array}$ & 26.02 & 0.36 \\
\hline CD97 & CD97 molecule & 26.06 & 0.33 \\
\hline OPN3 & Opsin 3 & 26.06 & 0.13 \\
\hline NPR3 & $\begin{array}{l}\text { Natriuretic peptide receptor C/guanylate } \\
\text { cyclase } \mathrm{C} \text { (atrionatriuretic peptide receptor } \mathrm{C} \text { ) }\end{array}$ & 26.13 & 0.13 \\
\hline FZD7 & Frizzled family receptor 7 & 26.29 & 0.51 \\
\hline S1PR2 & Sphingosine-1-phosphate receptor 2 & 26.38 & 0.17 \\
\hline OPN1SW & Opsin 1 (cone pigments), short-wave-sensitive & 26.39 & 0.08 \\
\hline EDNRA & Endothelin receptor type A & 26.44 & 0.29 \\
\hline CHRM2 & Cholinergic receptor, muscarinic 2 & 26.49 & 0.42 \\
\hline S1PR3 & Sphingosine-1-phosphate receptor 3 & 26.53 & 0.11 \\
\hline BDKRB1 & Bradykinin receptor $\mathrm{B} 1$ & 26.53 & 0.11 \\
\hline FZD2 & Frizzled family receptor 2 & 26.61 & 0.06 \\
\hline BDKRB2 & Bradykinin receptor B2 & 26.66 & 0.18 \\
\hline XPR1 & $\begin{array}{l}\text { Xenotropic and polytropic retrovirus receptor } \\
1\end{array}$ & 26.74 & 0.37 \\
\hline GPR157 & G protein-coupled receptor 157 & 27.04 & 0.11 \\
\hline CRCP & CGRP receptor component & 27.17 & 0.13 \\
\hline ELTD1 & $\begin{array}{l}\text { EGF, latrophilin and seven transmembrane } \\
\text { domain containing } 1\end{array}$ & 27.29 & 0.24 \\
\hline
\end{tabular}


Table A-3. (Continued)

\begin{tabular}{|c|c|c|c|}
\hline Gene & Description & $\begin{array}{l}\text { Average } \\
\text { CP }\end{array}$ & SD \\
\hline OGFR & Opioid growth factor receptor & 27.36 & 0.39 \\
\hline GPR153 & G protein-coupled receptor 153 & 27.51 & 0.51 \\
\hline FZD4 & Frizzled family receptor 4 & 27.54 & 0.35 \\
\hline $\begin{array}{l}\text { ADORA2 } \\
\text { B }\end{array}$ & Adenosine $\mathrm{A} 2 \mathrm{~b}$ receptor & 27.61 & 0.67 \\
\hline GPR125 & G protein-coupled receptor 125 & 27.62 & 0.47 \\
\hline SSTR1 & Somatostatin receptor 1 & 27.62 & 0.10 \\
\hline GPR124 & G protein-coupled receptor 124 & 27.68 & 0.02 \\
\hline PDGFRL & Platelet-derived growth factor receptor-like & 27.71 & 0.66 \\
\hline PTGER4 & Prostaglandin E receptor 4 (subtype EP4) & 27.71 & 0.31 \\
\hline LEPR & Leptin receptor & 27.74 & 0.22 \\
\hline MRGPRF & MAS-related GPR, member F & 27.78 & 0.45 \\
\hline $\begin{array}{l}\text { MRGPR } \\
\text { G }\end{array}$ & MAS-related GPR, member G & 27.85 & 0.91 \\
\hline S1PR1 & Sphingosine-1-phosphate receptor 1 & 27.99 & 0.94 \\
\hline NTSR1 & Neurotensin receptor 1 (high affinity) & 28.20 & 0.32 \\
\hline FZD8 & Frizzled family receptor 8 & 28.24 & 0.46 \\
\hline HRH1 & Histamine receptor $\mathrm{H} 1$ & 28.32 & 0.45 \\
\hline CHRM1 & Cholinergic receptor, muscarinic 1 & 28.34 & 0.83 \\
\hline PTGFR & Prostaglandin F receptor (FP) & 28.38 & 0.25 \\
\hline GPRC5B & $\begin{array}{l}\text { G protein-coupled receptor, family } \mathrm{C} \text {, group } 5 \text {, } \\
\text { member B }\end{array}$ & 28.39 & 0.13 \\
\hline GPR161 & G protein-coupled receptor 161 & 28.48 & 0.06 \\
\hline GPR37 & $\begin{array}{l}\text { G protein-coupled receptor } 37 \text { (endothelin } \\
\text { receptor type B-like) }\end{array}$ & 28.54 & 0.06 \\
\hline GPR152 & G protein-coupled receptor 152 & 28.60 & 0.04 \\
\hline F2RL1 & $\begin{array}{l}\text { Coagulation factor II (thrombin) receptor-like } \\
1\end{array}$ & 28.60 & 0.08 \\
\hline GPR27 & G protein-coupled receptor 27 & 28.64 & 0.17 \\
\hline GPR85 & G protein-coupled receptor 85 & 28.65 & 0.16 \\
\hline GPR39 & G protein-coupled receptor 39 & 28.66 & 0.23 \\
\hline LPAR3 & Lysophosphatidic acid receptor 3 & 28.67 & 0.25 \\
\hline CNR2 & Cannabinoid receptor 2 (macrophage) & 28.82 & 0.71 \\
\hline SMO & Smoothened, frizzled family receptor & 28.86 & 0.40 \\
\hline CXCR7 & Chemokine (C-X-C motif) receptor 7 & 29.00 & 0.97 \\
\hline GPR135 & G protein-coupled receptor 135 & 29.03 & 0.04 \\
\hline LPAR6 & Lysophosphatidic acid receptor 6 & 29.04 & 0.01 \\
\hline GPR173 & $\mathrm{G}$ protein-coupled receptor 173 & 29.04 & 0.20 \\
\hline
\end{tabular}


Table A-3. (Continued)

\begin{tabular}{|c|c|c|c|}
\hline Gene & Description & $\begin{array}{l}\text { Average } \\
\text { CP }\end{array}$ & SD \\
\hline GPR1 & G protein-coupled receptor 1 & 29.10 & 0.08 \\
\hline P2RY11 & $\begin{array}{l}\text { Purinergic receptor P2Y, G-protein coupled, } \\
11\end{array}$ & 29.13 & 0.03 \\
\hline OPRD1 & Opioid receptor, delta 1 & 29.29 & 1.06 \\
\hline CASR & Calcium-sensing receptor & 29.36 & 1.24 \\
\hline SSTR4 & Somatostatin receptor 4 & 29.38 & 0.59 \\
\hline GPR31 & G protein-coupled receptor 31 & 29.56 & 1.34 \\
\hline ADRA1D & Adrenergic, alpha-1D-, receptor & 29.62 & 0.64 \\
\hline GPR162 & G protein-coupled receptor 162 & 29.64 & 0.16 \\
\hline GABBR1 & $\begin{array}{l}\text { Gamma-aminobutyric acid (GABA) B } \\
\text { receptor, } 1\end{array}$ & 29.65 & 0.03 \\
\hline F2RL3 & $\begin{array}{l}\text { Coagulation factor II (thrombin) receptor-like } \\
3\end{array}$ & 29.71 & 0.78 \\
\hline GPR75 & G protein-coupled receptor 75 & 29.78 & 0.25 \\
\hline LPHN1 & Latrophilin 1 & 29.85 & 0.18 \\
\hline ADRB2 & Adrenergic, beta-2-, receptor, surface & 29.90 & 0.56 \\
\hline GPR37L1 & G protein-coupled receptor 37 like 1 & 29.96 & 0.52 \\
\hline GPR68 & G protein-coupled receptor 68 & 30.09 & 0.35 \\
\hline NPR1 & $\begin{array}{l}\text { Natriuretic peptide receptor A/guanylate } \\
\text { cyclase A (atrionatriuretic peptide receptor A) }\end{array}$ & 30.15 & 0.77 \\
\hline HTR7 & $\begin{array}{l}\text { 5-hydroxytryptamine (serotonin) receptor } 7 \\
\text { (adenylate cyclase-coupled) }\end{array}$ & 30.17 & 0.91 \\
\hline CHRM4 & Cholinergic receptor, muscarinic 4 & 30.22 & 0.46 \\
\hline GPR12 & G protein-coupled receptor 12 & 30.23 & 0.11 \\
\hline BAI2 & Brain-specific angiogenesis inhibitor 2 & 30.26 & 0.26 \\
\hline GPR55 & G protein-coupled receptor 55 & 30.37 & 0.07 \\
\hline CCBP2 & Chemokine binding protein 2 & 30.38 & 1.15 \\
\hline GPR126 & G protein-coupled receptor 126 & 30.40 & 0.41 \\
\hline GPR111 & G protein-coupled receptor 111 & 30.53 & 0.71 \\
\hline GPR97 & G protein-coupled receptor 97 & 30.56 & 0.47 \\
\hline LPAR5 & Lysophosphatidic acid receptor 5 & 30.61 & 0.18 \\
\hline MRGPRD & MAS-related GPR, member D & 30.65 & 0.22 \\
\hline TBXA2R & Thromboxane A2 receptor & 30.66 & 0.12 \\
\hline CCR3 & Chemokine (C-C motif) receptor 3 & 30.68 & 0.62 \\
\hline GPR63 & G protein-coupled receptor 63 & 30.70 & 0.16 \\
\hline PTGIR & Prostaglandin I2 (prostacyclin) receptor (IP) & 30.73 & 0.17 \\
\hline NTSR2 & Neurotensin receptor 2 & 30.76 & 0.08 \\
\hline GPR78 & G protein-coupled receptor 78 & 30.83 & 0.34 \\
\hline HTR3A & 5-hydroxytryptamine (serotonin) receptor $3 \mathrm{~A}$ & 31.12 & 0.91 \\
\hline
\end{tabular}


Table A-3. (Continued)

\begin{tabular}{|c|c|c|c|}
\hline Gene & Description & $\begin{array}{l}\text { Average } \\
\text { CP }\end{array}$ & SD \\
\hline FZD5 & Frizzled family receptor 5 & 31.18 & 1.01 \\
\hline GPR56 & G protein-coupled receptor 56 & 31.20 & 0.13 \\
\hline GPR3 & G protein-coupled receptor 3 & 31.26 & 0.35 \\
\hline DRD4 & Dopamine receptor D4 & 31.28 & 0.41 \\
\hline PTGER3 & Prostaglandin E receptor 3 (subtype EP3) & 31.28 & 0.03 \\
\hline RXFP3 & $\begin{array}{l}\text { Relaxin/insulin-like family peptide receptor } \\
3\end{array}$ & 31.29 & 0.37 \\
\hline CCR7 & Chemokine (C-C motif) receptor 7 & 31.33 & 0.18 \\
\hline NMUR1 & Neuromedin U receptor 1 & 31.34 & 0.74 \\
\hline TAAR5 & Trace amine associated receptor 5 & 31.35 & 0.48 \\
\hline MRGPRE & MAS-related GPR, member E & 31.37 & 0.12 \\
\hline LTB4R & Leukotriene B4 receptor & 31.40 & 0.20 \\
\hline GPR26 & G protein-coupled receptor 26 & 31.49 & 0.08 \\
\hline GPR65 & G protein-coupled receptor 65 & 31.51 & 0.71 \\
\hline GPR44 & G protein-coupled receptor 44 & 31.59 & 0.18 \\
\hline AVPR1A & Arginine vasopressin receptor $1 \mathrm{~A}$ & 31.63 & 0.23 \\
\hline GPR182 & G protein-coupled receptor 182 & 31.63 & 0.28 \\
\hline CRHR1 & Corticotropin releasing hormone receptor 1 & 31.64 & 0.16 \\
\hline CALCRL & Calcitonin receptor-like & 31.76 & 0.08 \\
\hline GNRHR & Gonadotropin-releasing hormone receptor & 31.76 & 0.74 \\
\hline XCR1 & Chemokine ( $\mathrm{C}$ motif) receptor 1 & 31.79 & 0.19 \\
\hline CX3CR1 & Chemokine (C-X3-C motif) receptor 1 & 31.79 & 0.34 \\
\hline GPR160 & G protein-coupled receptor 160 & 31.81 & 0.22 \\
\hline RHO & Rhodopsin & 31.81 & 0.54 \\
\hline CCR10 & Chemokine (C-C motif) receptor 10 & 31.82 & 0.04 \\
\hline PTGER1 & $\begin{array}{l}\text { Prostaglandin E receptor } 1 \text { (subtype EP1), } \\
42 \mathrm{kDa}\end{array}$ & 31.82 & 0.71 \\
\hline VIPR2 & Vasoactive intestinal peptide receptor 2 & 31.83 & 0.06 \\
\hline GPR133 & G protein-coupled receptor 133 & 31.86 & 0.18 \\
\hline NMUR2 & Neuromedin U receptor 2 & 31.87 & 0.42 \\
\hline NPSR1 & Neuropeptide $\mathrm{S}$ receptor 1 & 31.87 & 0.88 \\
\hline GPRC5D & $\begin{array}{l}\text { G protein-coupled receptor, family C, group } \\
5, \text { member D }\end{array}$ & 31.88 & 0.38 \\
\hline NPBWR1 & Neuropeptides B/W receptor 1 & 31.91 & 0.30 \\
\hline P2RY2 & $\begin{array}{l}\text { Purinergic receptor P2Y, G-protein coupled, } \\
2\end{array}$ & 31.94 & 0.99 \\
\hline CELSR3 & $\begin{array}{l}\text { Cadherin, EGF LAG seven-pass G-type } \\
\text { receptor } 3 \text { (flamingo homolog, Drosophila) }\end{array}$ & 31.99 & 0.06 \\
\hline ADORA1 & Adenosine A1 receptor & 32.01 & 0.30 \\
\hline
\end{tabular}


Table A-3. (Continued)

\begin{tabular}{|c|c|c|c|}
\hline Gene & Description & $\begin{array}{c}\text { Average } \\
\text { CP }\end{array}$ & SD \\
\hline OPRK1 & Opioid receptor, kappa 1 & 32.02 & 0.28 \\
\hline CXCR6 & Chemokine (C-X-C motif) receptor 6 & 32.06 & 0.37 \\
\hline CELSR2 & $\begin{array}{l}\text { Cadherin, EGF LAG seven-pass G-type } \\
\text { receptor } 2 \text { (flamingo homolog, Drosophila) }\end{array}$ & 32.07 & 0.11 \\
\hline ADRA1A & Adrenergic, alpha-1A-, receptor & 32.09 & 0.51 \\
\hline GPR179 & G protein-coupled receptor 179 & 32.12 & 0.11 \\
\hline P2RY6 & $\begin{array}{l}\text { Pyrimidinergic receptor P2Y, G-protein } \\
\text { coupled, } 6\end{array}$ & 32.20 & 0.37 \\
\hline S1PR5 & Sphingosine-1-phosphate receptor 5 & 32.26 & 0.42 \\
\hline GABBR2 & $\begin{array}{l}\text { Gamma-aminobutyric acid (GABA) B } \\
\text { receptor, } 2\end{array}$ & 32.29 & 0.95 \\
\hline ADRA2A & Adrenergic, alpha-2A-, receptor & 32.32 & 0.57 \\
\hline GPR174 & G protein-coupled receptor 174 & 32.32 & 0.17 \\
\hline GPR35 & $\mathrm{G}$ protein-coupled receptor 35 & 32.33 & 0.68 \\
\hline GPR62 & $\mathrm{G}$ protein-coupled receptor 62 & 32.34 & 0.40 \\
\hline ADRA1B & Adrenergic, alpha-1B-, receptor & 32.35 & 0.54 \\
\hline GPR183 & G protein-coupled receptor 183 & 32.39 & 0.11 \\
\hline GPR21 & $\mathrm{G}$ protein-coupled receptor 21 & 32.41 & 0.11 \\
\hline OPRM1 & Opioid receptor, mu 1 & 32.42 & 0.43 \\
\hline CCR4 & Chemokine (C-C motif) receptor 4 & 32.45 & 0.51 \\
\hline GPR142 & G protein-coupled receptor 142 & 32.45 & 0.25 \\
\hline $\begin{array}{l}\text { ADORA2 } \\
\text { A }\end{array}$ & Adenosine $\mathrm{A} 2 \mathrm{a}$ receptor & 32.47 & 0.01 \\
\hline HTR1B & 5-hydroxytryptamine (serotonin) receptor 1B & 32.48 & 0.89 \\
\hline GPR18 & $\mathrm{G}$ protein-coupled receptor 18 & 32.54 & 0.50 \\
\hline MTNR1A & Melatonin receptor $1 \mathrm{~A}$ & 32.56 & 0.01 \\
\hline PPYR1 & Pancreatic polypeptide receptor 1 & 32.59 & 0.04 \\
\hline LTB4R2 & Leukotriene B4 receptor 2 & 32.61 & 0.16 \\
\hline SORCS1 & $\begin{array}{l}\text { Sortilin-related VPS10 domain containing } \\
\text { receptor } 1\end{array}$ & 32.65 & 0.28 \\
\hline P2RY14 & $\begin{array}{l}\text { Purinergic receptor P2Y, G-protein coupled, } \\
14\end{array}$ & 32.68 & 0.76 \\
\hline GPR45 & G protein-coupled receptor 45 & 32.72 & 1.00 \\
\hline TACR3 & Tachykinin receptor 3 & 32.75 & 0.06 \\
\hline GPR101 & $\mathrm{G}$ protein-coupled receptor 101 & 32.81 & 0.15 \\
\hline GPR64 & $\mathrm{G}$ protein-coupled receptor 64 & 32.92 & 0.84 \\
\hline PTGDR & Prostaglandin D2 receptor (DP) & 32.92 & 1.05 \\
\hline GPR52 & $\mathrm{G}$ protein-coupled receptor 52 & 32.93 & 0.35 \\
\hline PTH1R & Parathyroid hormone 1 receptor & 32.94 & 0.09 \\
\hline
\end{tabular}


Table A-3. (Continued)

\begin{tabular}{|c|c|c|c|}
\hline Gene & Description & $\begin{array}{c}\text { Average } \\
\text { CP }\end{array}$ & SD \\
\hline LPAR2 & Lysophosphatidic acid receptor 2 & 32.95 & 0.47 \\
\hline CHRM3 & Cholinergic receptor, muscarinic 3 & 33.01 & 0.69 \\
\hline SSTR2 & Somatostatin receptor 2 & 33.03 & 1.60 \\
\hline GHRHR & Growth hormone releasing hormone receptor & 33.06 & 0.15 \\
\hline GPR77 & G protein-coupled receptor 77 & 33.09 & 0.08 \\
\hline CCKBR & Cholecystokinin B receptor & 33.12 & 1.15 \\
\hline HCAR1 & Hydroxycarboxylic acid receptor 1 & 33.12 & 0.45 \\
\hline NPBWR2 & Neuropeptides B/W receptor 2 & 33.17 & 0.65 \\
\hline NPFFR1 & Neuropeptide FF receptor 1 & 33.17 & 0.16 \\
\hline TAAR2 & Trace amine associated receptor 2 & 33.18 & 1.00 \\
\hline GPR19 & G protein-coupled receptor 19 & 33.20 & 1.78 \\
\hline PTAFR & Platelet-activating factor receptor & 33.28 & 0.05 \\
\hline GPR149 & G protein-coupled receptor 149 & 33.33 & 1.10 \\
\hline PROKR2 & Prokineticin receptor 2 & 33.33 & 1.58 \\
\hline GPR83 & G protein-coupled receptor 83 & 33.35 & 0.29 \\
\hline TRHR & Thyrotropin-releasing hormone receptor & 33.39 & 0.86 \\
\hline ADRB1 & Adrenergic, beta-1-, receptor & 33.39 & 0.81 \\
\hline GPR32 & G protein-coupled receptor 32 & 33.45 & 0.32 \\
\hline AVPR2 & Arginine vasopressin receptor 2 & 33.55 & 0.15 \\
\hline GPR115 & G protein-coupled receptor 115 & 33.59 & 0.69 \\
\hline GALR2 & GALANIN RECEPTOR 2 & 33.61 & 0.72 \\
\hline FZD9 & Frizzled family receptor 9 & 33.63 & 0.95 \\
\hline GPR148 & G protein-coupled receptor 148 & 33.66 & 0.16 \\
\hline HCAR2 & Hydroxycarboxylic acid receptor 2 & 33.66 & 0.88 \\
\hline FFAR2 & Free fatty acid receptor 2 & 33.68 & 0.64 \\
\hline MC5R & Melanocortin 5 receptor & 33.69 & 1.29 \\
\hline LPAR4 & Lysophosphatidic acid receptor 4 & 33.72 & 1.12 \\
\hline GPR113 & G protein-coupled receptor 113 & 33.73 & 0.32 \\
\hline GPR61 & G protein-coupled receptor 61 & 33.86 & 0.42 \\
\hline GPR144 & G protein-coupled receptor 144 & 33.87 & 0.60 \\
\hline P2RY13 & $\begin{array}{l}\text { Purinergic receptor P2Y, G-protein coupled, } \\
13\end{array}$ & 33.92 & 0.27 \\
\hline LPHN3 & Latrophilin 3 & 33.94 & 0.25 \\
\hline S1PR4 & Sphingosine-1-phosphate receptor 4 & 33.94 & 0.70 \\
\hline HTR1F & 5-hydroxytryptamine (serotonin) receptor $1 \mathrm{~F}$ & 33.96 & 1.01 \\
\hline GPR34 & G protein-coupled receptor 34 & 34.01 & 0.09 \\
\hline GPR82 & G protein-coupled receptor 82 & 34.14 & 0.64 \\
\hline DRD2 & Dopamine receptor D2 & 34.14 & 0.71 \\
\hline
\end{tabular}


Table A-3. (Continued)

\begin{tabular}{|c|c|c|c|}
\hline Gene & Description & $\begin{array}{l}\text { Average } \\
\text { CP }\end{array}$ & SD \\
\hline O3FAR1 & Omega-3 fatty acid receptor 1 & 34.15 & 0.04 \\
\hline MCHR1 & Melanin-concentrating hormone receptor 1 & 34.24 & 0.77 \\
\hline GPR84 & G protein-coupled receptor 84 & 34.28 & 0.67 \\
\hline P2RY4 & $\begin{array}{l}\text { Pyrimidinergic receptor P2Y, G-protein } \\
\text { coupled, } 4\end{array}$ & 34.29 & 0.97 \\
\hline FPR1 & Formyl peptide receptor 1 & 34.37 & 0.52 \\
\hline RGR & Retinal G protein coupled receptor & 34.42 & 1.29 \\
\hline P2RY1 & Purinergic receptor P2Y, G-protein coupled, 1 & 34.49 & 0.73 \\
\hline TACR1 & Tachykinin receptor 1 & 34.49 & 1.94 \\
\hline APLNR & Apelin receptor & 34.67 & 1.26 \\
\hline GCGR & Glucagon receptor & 34.68 & 0.04 \\
\hline GPR6 & G protein-coupled receptor 6 & 34.81 & 0.23 \\
\hline LGR5 & $\begin{array}{l}\text { Leucine-rich repeat containing G protein- } \\
\text { coupled receptor } 5\end{array}$ & 34.87 & 0.93 \\
\hline TAAR9 & $\begin{array}{l}\text { Trace amine associated receptor } 9 \\
\text { (gene/pseudogene) }\end{array}$ & 34.87 & 0.13 \\
\hline GPBAR1 & $\mathrm{G}$ protein-coupled bile acid receptor 1 & 34.89 & 2.65 \\
\hline BRS3 & Bombesin-like receptor 3 & 34.89 & 0.83 \\
\hline GPRC6A & $\begin{array}{l}\text { G protein-coupled receptor, family } \mathrm{C} \text {, group } 6 \text {, } \\
\text { member A }\end{array}$ & 35.08 & 1.90 \\
\hline GRM2 & Glutamate receptor, metabotropic 2 & 35.09 & 1.12 \\
\hline GPR116 & G protein-coupled receptor 116 & 35.10 & 0.33 \\
\hline GRM7 & Glutamate receptor, metabotropic 7 & 35.11 & 0.30 \\
\hline GRM1 & Glutamate receptor, metabotropic 1 & 35.12 & 0.96 \\
\hline GPR17 & G protein-coupled receptor 17 & 35.22 & 0.16 \\
\hline C5AR1 & Complement component 5 a receptor 1 & 35.26 & 0.31 \\
\hline CCR8 & Chemokine (C-C motif) receptor 8 & 35.37 & 1.27 \\
\hline RRH & $\begin{array}{l}\text { Retinal pigment epithelium-derived rhodopsin } \\
\text { homolog }\end{array}$ & 35.38 & 1.25 \\
\hline FZD3 & Frizzled family receptor 3 & 35.38 & 1.05 \\
\hline GPR119 & G protein-coupled receptor 119 & 35.42 & 0.51 \\
\hline CCR9 & Chemokine (C-C motif) receptor 9 & 35.44 & 1.12 \\
\hline GPR151 & G protein-coupled receptor 151 & 35.44 & 0.58 \\
\hline GPR22 & G protein-coupled receptor 22 & 35.45 & 4.15 \\
\hline CCR6 & Chemokine (C-C motif) receptor 6 & 35.57 & 1.35 \\
\hline GPR156 & G protein-coupled receptor 156 & 35.60 & 1.63 \\
\hline HTR6 & 5-hydroxytryptamine (serotonin) receptor 6 & 35.64 & 0.76 \\
\hline DARC & Duffy blood group, chemokine receptor & 35.66 & 1.05 \\
\hline GPR123 & G protein-coupled receptor 123 & 35.66 & 0.14 \\
\hline
\end{tabular}


Table A-3. (Continued)

\begin{tabular}{|c|c|c|c|}
\hline Gene & Description & $\begin{array}{c}\text { Average } \\
\text { CP }\end{array}$ & SD \\
\hline NPFFR2 & Neuropeptide FF receptor 2 & 35.68 & 0.19 \\
\hline CXCR5 & Chemokine (C-X-C motif) receptor 5 & 35.74 & 1.33 \\
\hline CMKLR1 & CHEMOKINE-LIKE RECEPTOR 1 & 35.97 & 1.71 \\
\hline TSHR & Thyroid stimulating hormone receptor & 36.04 & 0.53 \\
\hline CALCR & CALCITONIN RECEPTOR & 36.08 & 0.51 \\
\hline BAI1 & Brain-specific angiogenesis inhibitor 1 & 36.23 & 0.78 \\
\hline GPR171 & G protein-coupled receptor 171 & 36.24 & 2.38 \\
\hline GRIK3 & Glutamate receptor, ionotropic, kainate 3 & 36.26 & 0.05 \\
\hline NPY1R & Neuropeptide Y receptor Y1 & 36.30 & 0.52 \\
\hline GPR15 & G protein-coupled receptor 15 & 36.31 & 0.40 \\
\hline TAAR6 & Trace amine associated receptor 6 & 36.40 & 0.64 \\
\hline CXCR4 & Chemokine (C-X-C motif) receptor 4 & 36.42 & 0.36 \\
\hline PRLHR & Prolactin releasing hormone receptor & 36.42 & 1.16 \\
\hline MC4R & Melanocortin 4 receptor & 36.58 & 0.16 \\
\hline GPR112 & G protein-coupled receptor 112 & 36.60 & 0.06 \\
\hline GPR139 & G protein-coupled receptor 139 & 36.60 & 0.25 \\
\hline OPN5 & Opsin 5 & 36.64 & 0.62 \\
\hline GPR50 & G protein-coupled receptor 50 & 36.66 & 0.23 \\
\hline NPY2R & Neuropeptide Y receptor Y2 & 36.70 & 0.04 \\
\hline GPR87 & G protein-coupled receptor 87 & 36.70 & 2.73 \\
\hline GLP2R & Glucagon-like peptide 2 receptor & 36.79 & 0.76 \\
\hline OXGR1 & Oxoglutarate (alpha-ketoglutarate) receptor 1 & 36.97 & 0.08 \\
\hline CXCR2 & Chemokine (C-X-C motif) receptor 2 & 37.03 & 1.14 \\
\hline PROKR1 & Prokineticin receptor 1 & 37.06 & 0.43 \\
\hline P2RY10 & $\begin{array}{l}\text { Purinergic receptor P2Y, G-protein coupled, } \\
10\end{array}$ & 37.21 & 0.60 \\
\hline GPR128 & G protein-coupled receptor 128 & 37.24 & 0.11 \\
\hline GALR1 & Galanin receptor 1 & 37.34 & 3.77 \\
\hline GPR143 & G protein-coupled receptor 143 & 37.53 & 1.32 \\
\hline HRH4 & Histamine receptor $\mathrm{H} 4$ & 37.53 & 3.49 \\
\hline SSTR3 & Somatostatin receptor 3 & 37.56 & 0.65 \\
\hline TAAR1 & Trace amine associated receptor 1 & 37.66 & 0.49 \\
\hline $\begin{array}{l}\text { MRGPRX } \\
4\end{array}$ & MAS-related GPR, member X4 & 37.69 & 2.13 \\
\hline HTR2C & 5-hydroxytryptamine (serotonin) receptor $2 \mathrm{C}$ & 37.82 & 0.30 \\
\hline $\begin{array}{l}\text { ADCYAP } \\
1 R 1\end{array}$ & $\begin{array}{l}\text { Adenylate cyclase activating polypeptide } 1 \\
\text { (pituitary) receptor type I }\end{array}$ & 37.69 & 0.64 \\
\hline HTR2A & 5-hydroxytryptamine (serotonin) receptor $2 \mathrm{~A}$ & 37.83 & 3.07 \\
\hline FZD10 & Frizzled family receptor 10 & 38.04 & 0.27 \\
\hline
\end{tabular}


Table A-3. (Continued)

\begin{tabular}{|c|c|c|c|}
\hline Gene & Description & $\begin{array}{l}\text { Average } \\
\text { CP }\end{array}$ & SD \\
\hline SORCS3 & $\begin{array}{l}\text { Sortilin-related VPS10 domain containing } \\
\text { receptor } 3\end{array}$ & 38.10 & 2.69 \\
\hline $\begin{array}{l}\text { MRGPRX } \\
3\end{array}$ & MAS-related GPR, member X3 & 38.48 & 2.16 \\
\hline GRM8 & Glutamate receptor, metabotropic 8 & 38.52 & 0.54 \\
\hline ADORA3 & Adenosine $\mathrm{A} 3$ receptor & 38.79 & 1.72 \\
\hline $\begin{array}{l}\text { MRGPRX } \\
2\end{array}$ & MAS-related GPR, member X2 & 38.86 & 1.61 \\
\hline $\begin{array}{l}\text { CYSLTR } \\
1\end{array}$ & Cysteinyl leukotriene receptor 1 & 38.99 & 1.44 \\
\hline HTR4 & 5-hydroxytryptamine (serotonin) receptor 4 & 39.02 & 1.39 \\
\hline SCTR & Secretin receptor & 39.07 & 1.32 \\
\hline GPR141 & G protein-coupled receptor 141 & 39.27 & 1.04 \\
\hline MC2R & $\begin{array}{l}\text { Melanocortin } 2 \text { receptor (adrenocorticotropic } \\
\text { hormone) }\end{array}$ & 39.52 & 0.69 \\
\hline HTR1A & 5-hydroxytryptamine (serotonin) receptor $1 \mathrm{~A}$ & 39.70 & 0.42 \\
\hline AGTR2 & Angiotensin II receptor, type 2 & 40.00 & 0.00 \\
\hline BAI3 & Brain-specific angiogenesis inhibitor 3 & 40.00 & 0.00 \\
\hline CCRL2 & Chemokine (C-C motif) receptor-like 2 & 40.00 & 0.00 \\
\hline $\begin{array}{l}\text { CYSLTR } \\
2\end{array}$ & Cysteinyl leukotriene receptor 2 & 40.00 & 0.00 \\
\hline DRD5 & Dopamine receptor D5 & 40.00 & 0.00 \\
\hline GALR3 & Galanin receptor 3 & 40.00 & 0.00 \\
\hline GRM5 & Glutamate receptor, metabotropic 5 & 40.00 & 0.00 \\
\hline HCRTR1 & Hypocretin (orexin) receptor 1 & 40.00 & 0.00 \\
\hline LHCGR & $\begin{array}{l}\text { Luteinizing hormone/choriogonadotropin } \\
\text { receptor }\end{array}$ & 40.00 & 0.00 \\
\hline OPN4 & Opsin 4 & 40.00 & 0.00 \\
\hline P2RY12 & $\begin{array}{l}\text { Purinergic receptor P2Y, G-protein coupled, } \\
12\end{array}$ & 40.00 & 0.00 \\
\hline SUCNR1 & Succinate receptor 1 & 40.00 & 0.00 \\
\hline QRFPR & Pyroglutamylated RFamide peptide receptor & 40.00 & 0.00 \\
\hline
\end{tabular}




\section{VITA}

Amy Bogard was born in Memphis, TN in 1984. She was raised in York, PA and Jackson, TN. Amy earned a Bachelor of Science in Biology from the University of Tennessee Chattanooga in 2008. In August 2008 she entered the Integrated Program in Biomedical Sciences (IPBS) at the University of Tennessee Health Science Center under the Cell Signaling and Molecular Therapeutics track and in 2009 joined the laboratory of Dr. Rennolds Ostrom in the Department of Pharmacology. She is expected to earn her Ph.D. in December 2013. 